
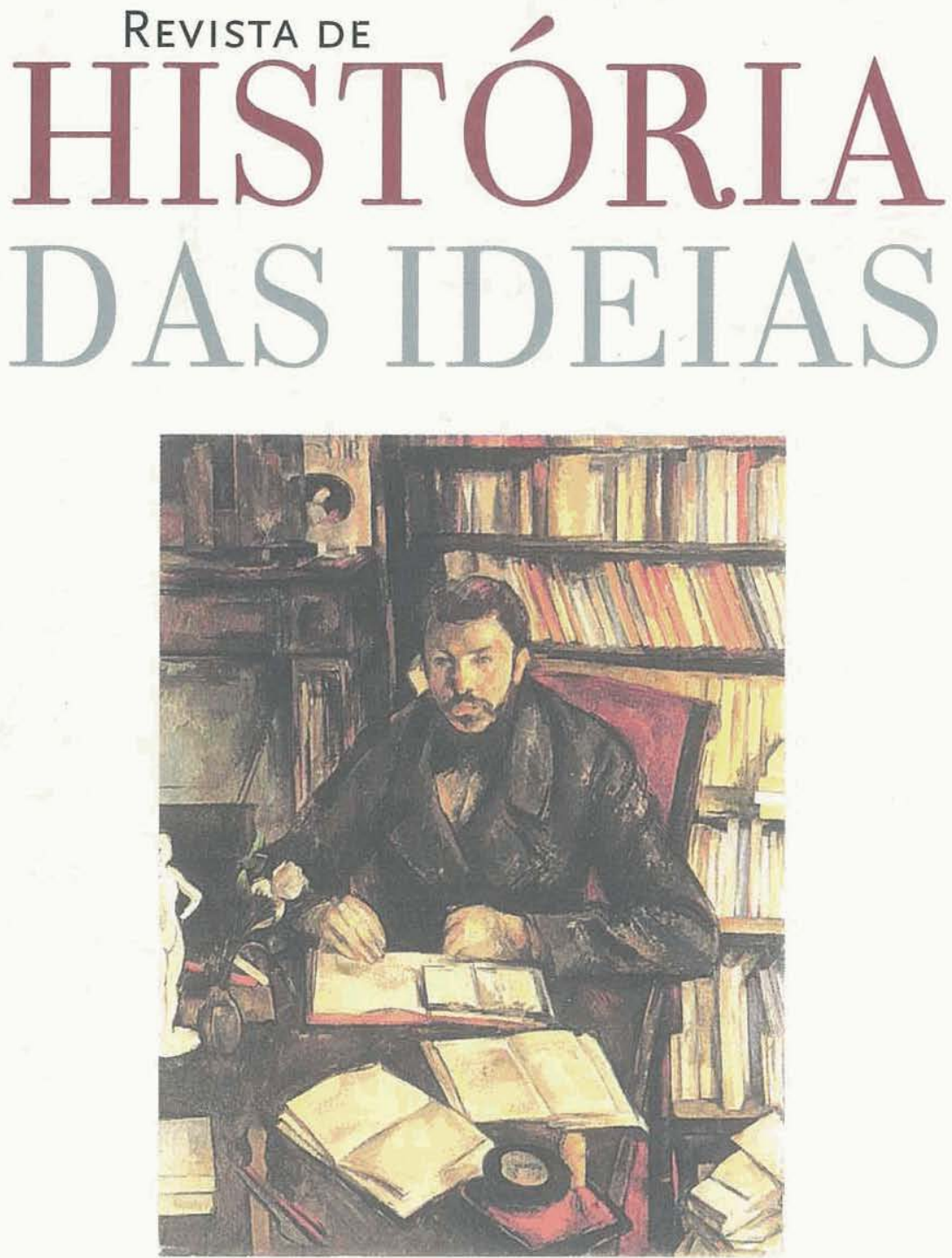

\title{
HISTÓRIA E LITERATURA
}

Volume 21, 2000

INSTITUTO DE HISTÓRIA E TEORIA DAS IDEIAS

FACULDADE DE LETRAS DA UNIVERSIDADE DE COIMBRA 


\section{SIDÓNIO E SIDONISMO ENTRE A HISTÓRIA E A LITERATURA**}

1. "Muito panegírico, alguma detracção mas pouca história"...

Situada historicamente após a implantação da República em 5 de Outubro de 1910 e a grave erosão político-institucional e sócioeconómica favorecida pela eclosão da Grande Guerra em meados de 1914, a decantada posição de charneira do artilheiro, lente coimbrão e "Presidente-Rei" Sidónio Bernardino Cardoso da Silva Pais (1872-1918) e do Sidonismo( $\left.{ }^{1}\right)$ na caracterização ideológica, cultural, político-

* Universidade do Minho. Centro de Estudos Interdisciplinares do Século XX.

** Este artigo reproduz parcialmente e com algumas adaptações o texto introdutório incluído na versão académica da dissertação de doutoramento intitulada Sidónio e Sidonismo. História e Mito, defendida na Universidade do Minho em 1999.

(') O Dicionário Complementar da Lingua Portuguesa (Porto, Editora Educação Nacional, 1936) de Augusto Moreno não refere o termo Sidonismo. Este aparece no Dicionório Gerale Analógico da Lingua Portuguesa (vol. 1, Porto, Edições "Ouro", 1948, pp. 1065 e 1066) de Artur Bivar: "Sidonismo, s.m. Situação politica portuguesa que foi presidida por Sidónio Pais". E aparece também: "Sidonista, s.m. Partidário do Sidonismo". O Novo Dicionário compacto da Lingua Portuguesa (vol. 2, Lisboa, Editorial Confluência Lda, 1960, p. 2196) de António Morais da Silva inclui: "Sidonismo, s.m. A situaçāo política que foi presidida por Sidónio Pais. O partido dos que defenderam a política desse presidente. Adj. Relativo ao sidonismo. S. 2 gén. Pessoa partidária do sistema governativo de Sidónio Pais". 
institucional e sócio-económica do regime republicano em Portugal entre 1890 e 1926, merece, sem dúvida, ser revisitada desde logo através de um número surpreendente de narrativas ilustrativas muitas delas da ténue fronteira entre as res factae e as res fictae $\left({ }^{2}\right)$.

As múltiplas interpretações urdidas em momentos distintos e segundo tendências historiográficas opostas parecem, pois, convergir no entendimento de se tratar de um mesmo ponto de viragem, situado a meio da experiência republicana portuguesa. Há, assim, várias nuances na fase histórica de 1917-1918: a viragem da Repíblica Velha para a Nova República Velha através de uma efémera e atribulada República Nova; a viragem de uma República Forte para uma República Fraca por intermédio de um frustrado e frustrante ensaio autocrático, que antecipa ou se assemelha em demasia à ditadura militar imposta pelo movimento militar de 28 de Maio de 1926; a viragem - mais subtil...do sistema liberocapitalista e parlamentar, em crise aguda, para um autoritarismo proto-fascista, que desemboca no fascismo estadonovista de Salazar; a viragem no confronto, sem tréguas, entre radicais jacobinos e moderados, entre cidade e campo, entre "caixeirismo jacobino" pequeno-burguês e a acidental "aliança" de camponeses, proprietários, classe média, sector do intport-export e alta burguesia industrial; enfim, a viragem provocada pela fractura de um sonho demoliberal que "derivou" no longevo "pesadelo" salazarista. Maneiras diversas de ver os mesmos sinais...

Mas se há uma notória convergência quanto à função de charneira do golpe de 5 a 8 de Dezembro de 1917, do regime presidencialista que se lhe seguiu por uns escassos meses e que se extingiu, pouco depois de 14 de Dezembro de 1918, com a morte do seu protagonista maior, uma boa parte da produção bibliográfica sobre a figura e o respectivo fenómeno resvalou para o maniqueísmo primário observado por Oliveira Marques: "Em relação ao Presidente

A partir da fixação do(s) termo(s) em Bivar e Morais acha-se reprodução em J. Almeida Costa e A. Sampaio e Melo, Dicionário da Lingua Portuguesa, $5^{n}$ ed., Porto, Porto Editora, s.d., p. 1311; e José Pedro Machado, Grande Dicionário da Lingua Portuguesa, vol. 11, Lisboa, Amigos do Livro Editores, 1981, p. 159.

${ }^{(2)}$ Ver sobre este tópico Hans-Robert Jauss, "Experiência histórica e ficção", in Gilbert Dadoffre, Certezas e incertezas da história. Três colóquios sobre História no Instituto Colegial Europeu, Lisboa, Pensamento-Editores Livreiros Lda, 1988, pp. 107-120. 
assassinado verifica-se um pouco o mesmo do que em relação a D. Carlos: muito panegírico, alguma detracção mas pouca história" (3). E o resultado vê-se nos "falsos" rastos seguidos e repetidos pela História como se fossem "verdadeiros"!... Rastos de um percurso que importa rever antes de avançarmos com as nossas dúvidas, interrogações e propostas teórico-metodológicas alternativas.

Em relação a Sidónio Pais tem havido, portanto, "pouca história", isto é, pouco trabalho historiográfico rigoroso (ou se se preferir científico), no meio de muito panegírico, apologia ou hagiografia política e no meio de tanta - não alguma, como sugere Oliveira Marques... - detracção, denegação ou deturpação.

Não é líquido classificar como produção historiográfica muitos dos textos nascidos "a quente" e "em cima" dos acontecimentos que preenchem os doze agitados e sombrios meses da governação dezembrista/sidonista, dispersos pelas páginas da imprensa de âmbito nacional e local e saídos dos prelos em papel de fraca qualidade sob a forma de folhetos, opúsculos ou livros de pequeno formato. São textos marcados pelas respectivas circunstâncias numa lógica de tensão, de confronto, de clivagem fortemente estimulada pelo perfil psicológico e pela postura teatral de Sidónio Pais, sempre fardado com o uniforme dos combatentes, a pé, de carro, a cavalo, nas varandas a saudar multidôes, no meio das criancinhas e de damas chics com vistosos chapéus em festas de assistência, nos tugúrios da capital a inaugurar as "suas" sopas, as célebres "sopas de Sidónio", precedidas pela do jornal O Século e pelas "Cozinhas Económicas" criadas pela duquesa de Palmela e pela marquesa de Rio Maior no reinado de D. Carlos $\left({ }^{4}\right) \ldots$

Para uns, Sidónio Pais era o cavaleiro da Providência generoso e protector dos infelizes ou o líder heróico aclamado por uma Nação desesperada; para outros, um ambicioso, um exibicionista, um falso republicano, enfim um mero aprendiz de tirano. A morte brusca a tiro

(3) Cf. A. H. de Oliveira Marques, Guia de história da $1^{a}$ Repuiblica portuguesa, Lisboa, Editorial Estampa, 1981, p. 481.

(4) Cf. Luísa Paiva Boléo, "Oito presidentes para a história (1910-1926). República primeiro acto", Magazine/Público, 7 Jan. 1996, p. 36. Ver também Idem, "Oito presidentes para a história (conclusāo). Até ao fim da república", Magazine/Público, 14 Jan. 1996, pp. 30-35. Sobre a "sopa para os pobres" de O Século, iniciativa lançada em 25 de Fevereiro de 1917 ver números do referido periódico nesse período. 
de revólver por um pretenso louco - José Júlio da Costa - que se julgava (ou foi mesmo?) incumbido da suprema missão de restituir a República aos próceres democrático-parlamentares e guerristas expulsos pelo dezembrismo - Bernardino Machado, Afonso Costa, Norton de Matos, etc. - fez dele, entre os que o choraram, um Mártir, um Grande Morto, quase um "Santo", enquanto os que inconfessadamente queriam vêlo morto puderam respirar de alívio...

\section{Os Hagiógrafos}

Ainda em vida, a tinta correu nos prelos para Ihe exaltar a acção e a obra ensaiada.

Um anónimo, muito provavelmente um publicista, escreveu e publicou a expensas dos Editores João Romano Torres \& $\mathrm{C}^{\mathrm{a}}$ um opúsculo intitulado Um Golpe de Estado. A Rezoltı̧̧̃o de 8 de Dezembro $\left({ }^{(5)}\right.$, espécie de crónica favorável à acção militar conspirativa, mas minuciosa e globalmente séria quanto à sucessão dos eventos ocorridos desde o anoitecer do dia 5 até ao "rescaldo" imediato do golpe triunfante.

Sem a mínima sombra de dúvida quanto à oportunidade e à patriótica missão de Sidónio Pais, Sérgio Gouveia redigiu um folheto que resume as medidas e os objectivos alcançados pelos mentores do golpe de 5 a 8 de Dezembro até 21 de Julho de 1918, data da abertura solene do Parlamento da República Nova, destacando o perfil de genuíno republicano e de indefectível patriota do comandante das forças concentradas no alto do Parque Eduardo VII $\left({ }^{6}\right)$.

A veemência hagiográfica deste autor contrasta, porém, pela contenção estilística e lógica, com os intensos eflúvios de sentimento e de gratidão que exalam de um primeiro texto de Maria Feio Patria e Coração. A Festa das Crianças em Sintra promovida pelo Chefe do Estado $\left({ }^{7}\right)$, de que a autora fora uma das entusiásticas organizadoras. Exalam,

(5) Ver Llm golpe de estado. A Revoluçăo de 8 de Dezembro, Lisboa, João Romano Torres \& $\mathrm{C}^{\mathrm{N}}$, s.d.

(6) Cf. Sergio Gouveia, O Dr. Sidonio Paes e a republica nova. 1910-1918, Lisboa, M. Pinto, 1918, p. 11.

(7) Ver Maria Feio, Patria e coraçăo. A Festa das crianças en Sintra promovida pelo chefe do estado, Lisboa, Edição do Gremio Técnico Português, 1918. 
também, do poema de Ondina $\left(^{8}\right)$ e do muito que ficou impresso e disperso em periódicos, opúsculos, folhetos e folhas volantes postas a circular de norte a sul do país. Todo esse material produzido em vida de Sidónio Pais e o que surgiu com a sua morte constitui, de facto, a base ideologémica da estratégia hagiográfica ou sacralizadora da política $\left({ }^{(}\right)$, urdida em torno de personagem adequada a esse fim quer pelas suas caracteríticas pessoais e carismáticas, quer pelas suas circunstâncias históricas, assaz dramáticas.

Deixando, aqui, de lado a base e implicações ideologémicas e mitanalíticas $\left({ }^{10}\right)$, atendamos à estratégia hagiográfica propriamente dita.

A hagiografia política, tal como a sintetizou Thuriane Seveno, pressupõe um processo de heroicização dos líderes políticos-observável, aliás, como uma constante da História Contemporânea - para o qual Max Weber deu um contributo essencial com a sua teoria da legitimidade carismática, postulando que a autoridade emanada desse "ideal-tipo" toma corpo quando surge uma personalidade à qual são atribuídas forças ou qualidades sobrenaturais, sobre-humanas ou, pelo menos, inacessiveis ao comum dos mortais. Entra, assim, em cena o "grande homem", o "homem providencial", o "super-homem", o herói em tomo do qual se desenvolve, segundo Seveno, uma literatura hagiográfica que "est certainement l'un des procédés fondamentaux à travers lesquels s'articulent les processus d'héroisation" ${ }^{11}$ ) e pela qual é possivvel identificar os temas, as imagens, os

(8) Ver Ondina, [Quem dá aos pobres empresta a Deus.] Homenagem a sua excelencia o senhor dr. Sidonio Paes presidente da republica portugueza. (Em beneficio da Assistencia 5 de Dezembro), s.l., s.n., s.d.

(9) Ver aplicação analítica ao caso Getúlio Vargas e Estado Novo brasileiro por Alcir Lenharo, Sacrnlização da política, Campinas, Papirus, 1986, pp. 169-205.

(19) Ver Alberto Filipe Araújo e Armando Malheiro da Silva, "Mitanálise e interdisciplinaridade. Subsídios para uma hermenêutica em educaçāo e em ciências sociais", Revista Portugutuesa de Educação, Braga, 8, 1-2, 1995, pp. 26-27; Idem, "Afonso Henriques, o mito fundador e a recorrência mítica. Para uma mitanálise do processo histórico portugutês", in $2^{\circ}$ Congresso histórico de Guimaräes. Actas do congresso. Vol. 3, Guimarāes, Câmara Municipal/Universidade do Minho, 1997, pp. 325-335; Armando B. Malheiro da Silva, "La Nation portugaise. Mythanalyse et récurrence", Inis. Centre de Recherche sur l'Intaginaire, Grenoble (15 - Mythe \& Nation), 1995, pp. 8995; e Idem, Sidónio e sidonismo. História e mito. Dissertação de doutoramento em História

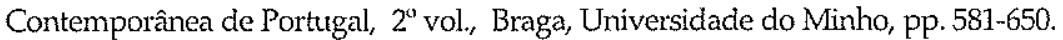

(ii) Cf. Thuriane Seveno, La Construction du "grand homme". Essai sur l'hagiographie politique en science politique. Thèse pour le doctorat d'État, Rennes, Université de Rennes 1, 1989, p. 2. 
símbolos cristalizados, bem como as expectativas, as esperanças, os investimentos afectivos concentrados nessa "figura especial e sacralizada". Para esta autora a hagiografia política é uma encenação e uma construção racional e afectiva no espaço do político, descrita e desmontada nos seus mecanismos internos através da análise comparativa de várias narrativas hagiográficas disponiveis sobre grandes líderes políticos (ela escolheu três Estaline, Pétain e De Gaulle). Como metodologia propedêutica afigura-senos fundamental, mas está longe de constituir uma hermenêutica de profundidade capaz de sondar, na medida do possivel, o "magma" emocional e motivacional (biopsíquico) desses temas, imagens, símbolos ou expectativas, de algum modo consubstanciados, desde há milénios, no património mitológico da Humanidade. Tal desiderato convoca, entre outras propostas de trabalho, a hermenêutica mitanalítica desenvolvida e aperfeiçoada por Gilbert Durand $\left.{ }^{12}\right)$.

Ainda em vida do "Presidente-Rei" foi publicado, em Londres, um folheto intitulado Portugal and the Allies por A. G. Loraine $\left({ }^{13}\right) \mathrm{e}$ destinado a contrariar junto da opinião pública britânica a campanha dos "carbonarios e democraticos" (muito mal vistos pelo autor e pelo prefaciador do texto) sobre o alegado pró-germanismo de Sidónio Pais.

Depois de morto, entre os que o choraram e por ele suspiraram, há um punhado de companheiros de jornada e de admiradores(as).

$\mathrm{Na}$ dianteira surgem logo as catorze folhinhas soltas, distribuídas ao longo do cortejo fúnebre, em 21 de Dezembro de 1918, do edifício da Câmara Municipal para o Mosteiro dos Jerónimos $\left({ }^{14}\right)$,

(12) Ver a obra fundamental de Gilbert Durand, As Estruturas antropológicas do imaginário. Introdução à argutetipologia geral, Lisboa, Editorial Presença, 1989. Sobre a totalidade da obra mitocrítica e mitanalítica deste autor até ao momento produzida e a dos seus seguidores, nomeadamente do sociólogo do imaginário Jean-Pierre Sironneau, ver Alberto Filipe Araújo, O "Homem Novo" no discurso pedagógico de João de Barros. Ensaio de mitanálise e de mitocrítica na educaçāo, Braga, Centro de Estudos em Educação e Psicologia/Instituto de Educaçāo e Psicologia/ Universidade do Minho, 1997, pp. 23-118.

(13) Ver A. G. Loraine, Portugal and the allies. A Message to Great Britain by... with a foreword by E. M. Tenison and a note on the treaties between England and Portugal, London, Hazell, Watson \& Viney, 1918.

(14) Catorze folhas avulsas e numeradas, S.l., s.n., s.d. Foram reunidas numa edição de luxo, com prefácio de Henrique Fonseca Chaves, Sidonio Paes na memoria de Portugal. [No Funeral de Sidonio Paes martir da Patria. Assassinado em Lisbon, aos quatorze de Dezembro de mil novecentos e desoito, pelos maos portugueses 
redigidas possivelmente pelo lente da Escola Médico-Cirúrgica do Porto, Ministro e Secretário de Estado da Instrução em todos os Governos sidonistas, doutor Alfredo de Magalhães $\left({ }^{15}\right)$.Surgem também os textos da $5^{\text {a }}$ Condessa de Ficalho, D. Maria Josefa de Melo, da professora Domitila de Carvalho, antiga condíscipula em Coimbra, do pe Valério A. Cordeiro, pregador e publicista católico com colaboração impressa no Correio da Manhã sob o pseudónimo de Argus, do Pe José Marinho e de Duarte Silva sobre os quais nada sabemos, do artilheiro e sócio efectivo da Academia de Ciências, Fernandes Costa, do poeta e jornalista republicano Afonso de Bragança, do inflamado José Agostinho nas suas Cartas Patrioticas, do esotérico e genial poeta Fernando Pessoa, Gomes Mota, dos minhotos António Tomás Quartim e Abílio Maia e outros vates $\left({ }^{16}\right)$. Páginas de prosa e de poesia onde a

aos quaes a suta grandeza fazia sombra, e levado para os Jeronymos em cortejo de verdadeira apotheose nacional, a vinte e um do mesmo mez $e$ anno], Lisboa, Empreza do Diario de Noticias, 1920 (a $3^{a}$ folha corresponde nesta edição às pp. 21-22). Nāo é possivel determinar com rigor a influência que estas folhinhas exerceram em muita da produçāo hagiográfica e avulsa publicada logo após a morte de Sidónio Pais, mas há vários casos flagrantes como o do folheto Quem era o $D$ r. Sidonio Paes. Suas qualidades e biografia, Lisboa, Livraria Barateira, s.d.

$\left({ }^{15}\right)$ Henrique Fonseca Chaves hesitou em atribuir a autoria das folhas ou a professores anónimos das Escolas Normais ou a Alfredo de Magalhães. Por sua vez o jornal A Situação de 27 de Dezembro de 1918 incluiu a notícia de que essas folhas iriam sair reunidas num opúsculo editado com prefácio de Alfredo de Magalhães. Ver Joāo Medina, Morte e transfiguração de Sidónio Pais, Lisboa, Ediçōes Cosmos, 1994, p. 169.

(1') Ver Condessa de Ficalho, A Transladaçāo. Simples impressões sinceras, Lisboa, Livraria Aillaud, 1919; Domitila de Carvalho, Liçāo às alumas do Liceu de Garrett, no $30^{\circ}$ dia do falecinento do sr. dr. Sidóntio Paes pela professora..., Lisboa, Oficinas Graficas Editoras, [1919]; Valério A. Cordeiro, "Dr. Sidónio Paes. Allocução ás alumnas do

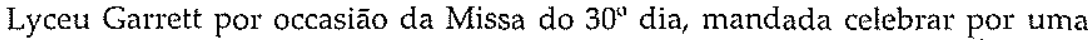
commissão das mesmas, na egreja da Encarnação. 15-1-1919", in Idem, Á Sombrn da cruz. Allocuçōes funebres pelo..., Lisboa, Edição do Autor, 1922, pp. 21-26; José Marinho, Oraçĩo funebre proferida nas exequias solemnes que, por alma do stur. Presidente da Republica, dr. Sidonio Paes, de saídosa memoria foram mandadas celebrar na Catedral de Coritiba, pelo Consul de Portugal, Dr. Aristides de Sousa Mendes, no dia 21 de Dezembro de 1918, e em que oficiou de pontifical o exno. e rumo. snr. D. Alberto Jose Gonsalves, Bispo de Ribeirño Preto, Coritiba, 1918; Duarte Silva, O Salvador da pátria portuguesa. Bicas, 20 de Agosto de 1918. [S.l.], Tip. Andrade, 1918, 1 fl.; Fernandes Costa, Elogio academico do dr. Sidonio Pais. Lido na sessāo ordinaria da "Classe de Letras" da Acadenia das Sciencias de Lisboa, a 26 de dezembro de 1918 por... Edição 
figura de Sidónio Pais aparece cumulada de epítetos mais ou menos profundos do ponto de vista mítico-simbólico - o Grande Português, o Libertador "corajoso e heróico" como D. João I, como o Condestável Nun'Álvares, como o Infante de Sagres ou como Vasco da Gama, o novo Encoberto ou D. Sebastião, o novo D. Pedro V, Napoleão Bonaparte, o Salvador da Pátria, o "Predestinado condutor de Povos", - Protector dos Humildes, o Herói e "Santo Apóstolo do Ideal", o Grande Morto, o "Bem-Amado"...

Num alinhamento misto, não apenas hagiográfico ou apologético, mas também alegadamente representativo da "verdade" histórica, podemos situar os diversos contributos do incansável "cronista" Francisco da Rocha Martins, do sidonista Pedro Fazenda, do antigo dissidente progressista, líder do centrismo e neurocirurgião galardoado com o Prémio Nobel (1949) António Caetano de Abreu Freire Egas Moniz, do ex-jacobino José Soares da Cunha e Costa, da melífula e emocionada biógrafa Maria Feio, rotulada de "sidonista espírita" por João Medina $\left({ }^{17}\right)$, de Alfredo de Freitas Branco conhecido pelo título nobiliárquico de Visconde do Porto da Cruz, do desconhecido Roma Neto, do polémico Homem Christo Filho, agente da propaganda dos governos sidonistas em França e futuro admirador de Benito

fóra do mercado, e offerecida pelo conferente e editores aos amigos do Dr. Sidonio Pais, Lisboa, Livrarias Aillaud e Bertrand, 1919; Afonso de Bragança, "Abaixo! Panfleto politico semanal. Numero primeiro dedicado á memoria do grande portuguez que foi Sidonio Paes", in Idem, Amostras sem valor, Figueira da Foz, 1921; José Agostinho de [Oliveira], Cartas patrioticas, I - O Grande libertador, Porto, Livraria Editora A.J. d'Almeida, [1919]; Fernando Pessoa, "À Memória do Presidente-Rei Sidónio Pais", Acção, orgão do Nícleo de Acçño Nacional, Lisboa, (4), 27 Fev. 1920 (Idem, À Menória do Presidente-Rei Sidonio Paes, Lisboa, Editorial Império, 1940); [dem, "O Sentido do Sidonismo", in Idem, Da Repuiblica (1910-1935). Recolla de textos Maria Isabel Rocheta e Maria Paula Morāo. Introduçāo e organizaçāo Joel Serrão, Lisboa, Ática, 1978, pp. 231-267; Idem, "Na Farmácia do Evaristo", in Ibidem, pp. 271-294; Gomes Mota, [Ao Grande môrto, no grande presidente]. No $1^{\circ}$ aniversario da morte do Dr. Sidonio Paes, Presidente da Republica en Portugal, benemerito da patria chanado á divina presença en 14 de Dezembro de 1918. Hontenagem do auctor, s.l., s.n., s.d.; António Tomás Quartim, Sidónio Pais. Homenagem de..., Viana, s.n., 1919; Abilio Maia, Na morte de Sidonio Paes (Com unta nota referente ao actual momento politico de Portugal), Tuy, Tipografia Regional, 1919; e O Bent-Amado. Recolha de Alfredo Ferreira, Lisboa, Papelaria Camões, 1919.

(17) Cf. João Medina, Morte e transfiguraçōo de Sidónio Pais, ob. cit., p. 42. 
Mussolini, de João de Castro Osório de Oliveira, filho de Paulino Oliveira e da escritora republicana Ana de Castro Osório, jornalista, escritor e historiador que aderiu, no início da década de vinte, ao ideal fascista e de Teófilo Duarte, um dos "heróis de Dezembro", apodado de "Iouco" por José Relvas nas suas Memórias Políticas ${ }^{(18)}$.

Num plano essencialmente "técnico" avultam sobretudo dois trabalhos com irrefragável interesse histórico: o do escritor, prestigiado historiador da literatura portuguesa e nacionalista convicto, Fidelino de Figueiredo, que, logo em 1919, se apressou a publicar o relatório da sua acção como director da Biblioteca Nacional de Fevereiro de 1918 a Fevereiro de $\left.191{ }^{(19}\right)$, cargo que voltou a assumir após 28 de Maio e sendo de novo Ministro de Instrução o professor Alfredo de Magalhães (ministro e colaborador de Sidónio Pais); e os relatórios dos exames periciais no cadáver de Sidónio Pais, no seu vestuário e na arma agressora $\left({ }^{20}\right)$, publicados como separata da revista do Instituto de Medicina Legal de Lisboa, fundado curiosamente em 1918.

Rocha Martins escreveu imenso e a sua escrita reflectiu, à maneira do jornalista-repórter do seu tempo $\left({ }^{(21)}\right.$, tanto os eventos que

${ }^{(1)}$ Cf. José Relvas, Memórias políticas, vol. 2, Lisboa, Terra Livre, 1978, p. 93. Sobre o curriculum vitae deste irriquieto militar, arrebatado seguidor de Sidónio Pais e futuro colaborador de Salazar ver João Medina, Salazar e os fascistas. Salazarismo e nacional-sindicalismo a história dum conflito, 1932/1935, Amadora, Livraria Bertrand, 1978, p. 58; e Idem, Morte e transfiguração de Sidónio Pais, ob. cit., pp. 184-186. Sobre as Memórias de José Relvas, o seu contexto histórico e conteúdo sugere-se a leitura do sugestivo e longo estudo do erudito A. Álvaro Dória, "Gabinete de Leitura. Um livro, uma época", Bracara Augusta, Braga, 33(75-76), Jan.-Dez. 1979, pp. 411 482 e 34, tomo 2(78), Jul.-Dez. 1980, pp. 731-935.

(19) Ver Fidelino de Figueiredo, Como dirigi a Bibliotheca Nacional. (Fevereiro de 1918 a Fevereiro de 1919), Lisboa, Livraria Clássica Editora A. M. Teixeira, 1919.

(20) Ver Asdrubal António de Aguiar, Exames pericines no cadaver do presidente da república dr. Sidonio Paes, no vestuario e na arma aggressora por... Chefe de Serviço no Instituto de Medicina Legal de Lisboa, Lisboa, Instituto de Medicina Legal de Lisboa, 1921.

(21) Em carta para o "Meu caro Theofilo Duarte" datada de 17 de Janeiro de 1942 e escrita para agradecer a "oferta do seu livro [Sidonio Pais e o seu Consulado] e a amavel dedicatoria", assumiu esta faceta e justificou o seu métier: "[...] Eu nunca desejei ser mais do que um cronista da minha epoca, com os defeitos inerentes a quem a viveu com certo nervosismo. Eis tudo. Os que falam de min, julgando me a faser historia, nāo me Jeram. Eu sou um reporter do meu 
presenciou, como as situações histórico-políticas em que participou intensamente. Em sucessivos números da revista ilustrada $A B C$, pelo transcurso do ano de 1921, deixou o seu testemunho, a sua visão e o seu "retoque" cronístico para a memória de Sidónio Pais, tendo logo reunido essa prosa em livro com o busto de Sidónio na capa, captado de frente, e o sugestivo título de Memórias sobre Sidonio Paes. A profusão de retratos dos muitos intervenientes e protagonistas do período em foco e a reprodução de alguns documentos autógrafos do malogrado Presidente da República constituem, sem dúvida, um acervo informativo interessante ao longo de doze capítulos e de trezentas e cinquenta páginas. Ao princípio é o cenário conspirativo do jornal $A$ Lucta e no fim a impressionante apoteose trágica do cortejo fúnebre dos restos mortais de Sidónio, havendo pelo meio da narrativa, algo ziguezagueante, dados biográficos distorcidos, muitos diálogos de veracidade duvidosa, a sucessão de episódios - épicos uns, prosaicos outros e trágicos alguns... - que haveriam de ficar famosos ou ainda vários efeitos literários de discutível valor historiográfico como o daquele cão da rua, sujo e faminto, que acompanhou o carro da Cruz Vermelha com o corpo de Sidónio até ao edifício da Câmara Municipal...

Rocha Martins, sem dúvida bem informado acerca dos factos e dos protagonistas, desenhou habilmente, sem cuidados de rigor histórico é certo, mas também sem quaisquer intuitos de sofisticada interpretação ideológico-política, a imagem de um herói romântico, apaixonado, corajoso, voluntarista, generoso, cercado pelos adversários e traído pelos apoiantes, mas que "a turba relembra, vendo-o sempre vivo, recortado sob o ceu azul da Patria, quando não é já senão mais um fantasma rápido, extranho, na História de Portugal" $\left({ }^{2}\right)$. Eis, enfim,

tempo que em vez de registar facadas, arquiva espadeiradas e canhoneios e parlengas. A analise dos homens que conheci (dos chefes com quem lidei) essa é puramente observada sem o menor rasquicio de os empurrar para onde não tem lugar. Modestosinho, tenho vivido da pena e em penas me encontro. Se algum dia os meus livros servirem de base ao historiador - como agora deram ingresso numa obra espanhola, sendo subsidios - o futuro cronista nāo tera que ter medo do meu facciosismo. Não o tive e agora, cada vez menos" (Arquivo Pessoal de Teófilo Duarte [A.P.T.D.], Herdade do Cego, Fronteira, Sidonio Paes e o set Consulado. Correspondencia sobre o livro).

${ }^{\left({ }^{2}\right)}$ Cf. [Francisco da] Rocha Martins, Memorias sobre Sidonio Pnes, Lisboa, Edição da Sociedade Editorial ABC Limitada, 1921, p. 352. 
mais uma importante achega para a pretensa "mitificação" de Sidónio Pais, que a actual historiografia tem aceite, porque segue a linha desmitologizadora segundo a qual o mito é lenda, ficção, representação efabulada, essencialmente racional e cultural, da realidade $\left({ }^{23}\right)$.

O depoimento do advogado ex-centrista e sidonista Pedro Fazenda seguiu um trilho diverso. Reflectindo sobre alguns dados da conjuntura de crise em Portugal - os factores étnicos, morais, históricos, sociais, económicos e políticos, que incluem o espectro partidário anterior a 1918 e posterior até 1921- apresentou Sidónio Pais e a sua acção - o sidonismo, espécie de "personificação duma aspiração nacional" -, como uma "formula d'atração, uma tactica politica; mas acima de tudo um pensamento de justiça moral" $\left.{ }^{24}\right)$. E se Sidónio não conseguiu os seus intentos foi por culpa dos "erros e incapacidade dos políticos profissionaes que o cercavam, causa dos desmandos e violencias que lhe assacaram" $\left.{ }^{\prime 25}\right)$. Mas também por sua culpa: avançou só, descrente da "influencia extravagante dos partidos" $\left({ }^{26}\right)$, pouco empenhado no "seu" Partido Nacional Republicano, que "nāo passou duma ficção!" $\left({ }^{2}\right)$, seduzido pela ideia de uma regeneração rápida à

${ }^{(23)}$ Roland Barthes escreveu, por isso, que o mito "nâo nega as coisas, a sua função é, pelo contrário, falar delas: simplesmente, ele purifica-as, torna-as inocentes, funda-as enquanto natureza e eternidade" (Cf. Idem, Mitologias, Lisboa, Edições 70, 1973, p. 120). Não é esta, porém, a nossa noção operatória de mito.

${ }^{\left({ }^{2}\right)}$ E prosseguiu escrevendo: "Estava nisso a sua grande força; não no apoio duma facçāo, mas no aplauso do Paiz a esse processo preconisado e reconciliador. Dominada a demagogia, qual fosse a sua divisa, a reconciliaçăo far-se-ia expontaneamente, insensivelmente entre todas as camadas sociais. Voltaria a tranquilidade publica e o Paiz, liberto da anarquia política, prosperaria em todos os ramos da economia nacional, entravada pela acção miseravel dos partidos. O receio dêsse desideratum creou a lenda demagogica que faz de Sidonio Paes um traidor - monarquico mascarado - que explorada e propagada pelos verdadeiros renegados, tal qual o que se passou na Russia bolchevista, em que o judeu Bronstein, que se diz Lenine, fazia passar Kerensky por judeu para o tornar execrado da populaça. Era um republicano moderado, talentoso, que fazia da transigencia aparente a sua força real e convincente" (Cf. Pedro Fazenda, A Crise politica. (Em Portugal), Lisboa, Lumen Empresa Internacional Editora, 1921, pp. 86-87).

(25) Cf. Ibidem, p. 89.

(26) Cf. Ibidem, p. 89.

$\left({ }^{27}\right)$ Cf. Ibidem, p. 88. 
custa de um esforço hercúleo e da confiança calorosa tributada pelo país...

Esta perspectiva parece importada do grosso livro do correligionário e amigo Egas Moniz, concebido como um registo memorialístico e um "album" de documentos, reproduzidos, aliás, com bastante rigor. Unt ano de política $\left.{ }^{28}\right)$ é a evocação autobiográfica de um cientista iniciado nas lides políticas da dissidência progressista de José de Alpuim, combatendo sem tréguas o franquismo, regressado à Câmara como deputado às Constituintes da recém-instaurada República, prisioneiro na sequência da intentona chefiada por Machado Santos em 13 de Dezembro de 1916, fundador do Partido Centrista em 1917, apoiante do golpe de 5 de Dezembro desse ano, diplomata e ministro envolvido tanto nas negociaçoes para o reatamento das relações de Portugal com a Santa Sé, como à frente da delegação portuguesa à Conferência de $\operatorname{Paz}$ em Paris $\left({ }^{29}\right) \ldots$

Egas Moniz manteve-se fiel a Sidónio Pais até ao fim e apesar das divergências. Mas insistiu num diferendō que terá pairado ameaçador sobre as relações políticas com o Presidente da República Nova: a opção entre parlamentarismo ou presidencialismo. À clara preferência presidencialista de Sidónio Pais opôs um modelo parlamentar com dissolução e liberto dos vícios anteriores. Omite, porém, que até meados de 1918 o "seu" Jornal da Tarde, inicialmente órgão do Partido Centrista e depois tribuna do P.N.R., fez campanha pelo presidencialismo. Mas para além deste tópico, a desorganização e a fragilidade do partido comum foi também motivo de séria preocupação como se depreende da carta que escreveu em 9 de Agosto de 1918 ao Presidente, transcrita fielmente no livro $\left({ }^{30}\right)$ e cujo original se conserva, embora truncado, no Arquivo Pessoal de Sidónio Pais. Numa outra carta, escrita na sequência da tragédia de 14 de Dezembro de 1918 a um amigo íntimo, gravou umas palavras de apreciação citadas na íntegra: "Homem cheio de virtudes e extraordinárias

$\left({ }^{28}\right)$ Ver Egas Moniz, Um ano de politica, Lisboa, Portugal-Brasil Limitada Sociedade Editora, 1919.

$\left({ }^{29}\right)$ Sobre esta intensa e complexa actividade ver Armando B. Malheiro da Silva, "Egas Moniz e a política. Notas avulsas para uma biografia indiscreta", in Colectânea de estudos sobre Egas Moniz, Coimbra, Livraria Minerva, 2000.

(3i) Ver Egas Moniz, Um ano de politica, ob. cit., pp. 144-148. 
qualidades que um desvairo messianico perdeu". Comentando esta observação de fino recorte psicológico, Egas Moniz lamentou, post mortem, que o malogrado Presidente se tivesse tornado "quási um fanático do sistema presidencialista", que se tivesse desvanecido com "o mando que previa mais forte a dentro dessa fórmula governativa" e que se deixasse embalar pelas inúmeras manifestações de apreço e de apoio - "As aclamações, as palavras dos que o cercavam e o meio amigo que encontrava por toda a parte, radicaram-lhe no espírito a convicção de um messianismo que os argumentos já não conseguiam dominar" $\left.{ }^{(31}\right)$. Esta lúcida observação, que não caiu muito bem junto dos sidonistas mais apologetas, surgiu de passagem e de permeio com tiradas de rasgado apoio à política sidonista, nomeadamente no respeitante à conduta de guerra. A anteceder o relato do seu papel à frente da delegação portuguesa na Conferência de Paz, Egas Moniz refutou com veemência a campanha anti-dezembrista e anti-sidonista orquestrada no estrangeiro pela "equipa de guerra" (Bernardino Machado, Afonso Costa, Norton de Matos, João Chagas, Alexandre Braga, Leote do Rego, que chefiara a divisão naval encarregue da defesa contra os submarinos alemães) e assessorada por alguns publicistas correligionários como Paulo Osório. Estas vozes denunciavam com ardor a alegada germanofilia e a deliberada atitude de abandono do Corpo Expedicionário Português (C.E.P.) à sua sorte por parte da governação sidonista.

Ao contrário de Egas Moniz não foi Cunha e Costa um colaborador directo do Presidente assassinado, mas revelou-se um estrénuo esgrimista da pena em defesa da sua memória, atacada à direita e à esquerda por monárquicos e por republicanos oposicionistas.

Logo em 1919 no jornal católico A Época, do conselheiro Fernando Sousa (Nemo), publicou, entre 27 de Julho e 11 de Setembro, uma série de artigos de refutação das acusações urdidas pelos intervencionistas ou guerristas segundo as quais o Sidonismo deu cobertura a uma conduta de guerra defectista e germanófila, responsável pelo enfraquecimento do C.E.P., consequentemente pela derrota militar na batalha do Lys em 9 de Abril de 1918 e pela dificílima situação internacional de Portugal nas vésperas da Conferência de Paz. Refutando a argumentação disseminada pela imprensa nacional e estrangeira, bem como por uma variedade de

(') Cf. Ibidem, p. 157. 
folhetos, opúsculos e livros, e integrada na campanha de descrédito político lançada contra a situação sidonista $\left({ }^{32}\right)$, Cunha e Costa sustentou, contrapondo a sua verdade dos factos e as suas provas documentais, que Sidónio Pais não foi germanófilo, não traiu o apoio firmado com os Aliados, nem tão pouco a Pátria, prosseguindo antes uma política claramente aliadófila e que o desaire militar de 9 de Abril, a desorganização do C.E.P. e a debilidade da posiçāo portuguesa no concerto das nações aliadas ficaram a dever-se aos intervencionistas $e$ aos governos dominados pelos democráticos com a cumplicidade dos evolucionistas. A sua aposta político-partidária numa participação forte no teatro europeu da guerra levou-os a forçarem a Inglaterra a pedir a nossa presença militar e a organizarem sem suficientes meios, nem a necessária preparação técnico-militar os efectivos do C.E.P. Esta é a versão de Cunha e Costa, de todo contrária aos argumentos políticoideológicos de Augusto Casimiro, responsável pela organização do Livro Branco $\left({ }^{33}\right)$ e grande amigo e colaborador do general Norton de Matos, o grande obreiro daquilo a que a propaganda guerrista enfatizou como "milagre de Tancos"( $\left.{ }^{34}\right)$. Augusto Casimiro contra-atacou com um conjunto de textos publicados no jornal $A$ Vitória, entre o final de Julho e o início de Outubro de 1919, reunidos depois em livro, adiante citado.

Não se cingiu, porém, a este importante tópico o causídico Cunha e Costa, empunhando, também, a pena noutro confronto urgente: justificar a política de conciliação com a Igreja Católica. Fê-lo num opúsculo intitulado A Egreja Catholica e Sidonio Paes e incluído como primeiro - e único!... - volume de uma obra planeada com o título

(32) Uma súmula criteriosa pode ver-se em José António Sequeira Gonçalves, Sidónio Pais e a participação portuguesa na guerra de 1914-1918. Dissertaçāo de Mestrado orientada pelo professor doutor João Medina, 2 vols., Lisboa, Faculdade de Letras/Universidade de Lisboa, 1989 (fotocop.); e Nuno Severiano Teixeira, O Poder ea guerra, 1914-1918. Objectivos nacionais e estratégins politicas na entrada de Portugal na Grande Guerra, Lisboa, Editorial Estampa, 1996, pp. 19-26.

(33) Ver Livro Branco. Documentos apresentados ao Congresso da República em 1920. Portugal no conflito europeu $1^{a}$ parte. Negociações até à declaração de guerra, Lisboa, Imprensa Nacional, 1920. A $1^{a}$ e $2^{3}$ parte (inédita) foram recentemente publicadas pelo Ministério dos Negócios Estrangeiros.

(34) Ver Adelino Mendes e Oldemiro César, A Cooperação de Portugal na guerra europeia. O Milagre de Tancos, Lisboa, Empresa Lusitana Editora, s.d. 
O Grande Presidente. E ao longo de oito capítulos desenvolveu a seguinte estratégia: a "fobia religiosa" ou o radicalismo anti-clerical da República saída do 5 de Outubro tornara-se insustentável, injusta e contrária à índole católica e tolerante do povo português, pelo que Sidónio Pais ao encaminhar-se para a paz religiosa reconheceu tão sentida e profunda aspiração nacional, renegando o seu passado de jacobino e livre-pensador. Para Cunha e Costa os actos governativos e a postura conciliadora de Sidónio Pais, exibida até ao próprio dia em que foi assassinado (esteve presente no solene Te Deum celebrado na Basílica da Estrela, a 14 de Dezembro de 1918, pela vitória dos exércitos aliados), confirmavam uma evolução para o campo católico, perceptível já na fase em que parecia ser um indiferente em matéria religiosa e alinhava com "o anti-clericalismo dos seus correligionários". Apesar de algum rigor histórico na representação dos principais factos da chamada "questão religiosa" sob a República Nova e do relacionamento tenso e difícil dos católicos com a República Velha, Cunha e Costa não hesitou em os "ajustar" e, sobretudo na parte final do opúsculo, em expor a sua "imagem" do Presidente Sidónio Pais, apresentando-o quase como um católico converso e sincero que se não fosse assassinado satisfaria todas as reclamaçōes dos católicos e dos seus bispos $\left({ }^{35}\right)$. Davà, assim, razão, mas pela via inversa, aos detractores que foram "pintando" Sidónio em estreito conluio com a famigerada reacção monárquica e jesuítica!...

Embora bem vincado, o cariz hagiográfico deste contributo não é comparável ao do livrinho de Maria Feio, escrito com o propósito flagrante de proteger a "figura imaculada" de Sidónio Pais das mais díspares e "malévolas" acusações.

A autora confessa, aliás, no título - Sidonio Paes atravez do coração $\left({ }^{36}\right)$ - que o seu olhar radicou no "coração", na afectividade, na mais vibrante subjectividade. Declarando logo no começo que não se tratava de um livro político, mas apenas "de uma these de psicologia e

$\left.{ }^{(35}\right)$ Uma sintese do conteúdo deste trabalho de Cunha e Costa pode ver-se em Armando B. Malheiro da Silva, "Os Católicos e a 'República Nova' (19171918): da 'questāo religiosa' à mitologia nacional", Lusitania Sacra, Lisboa, 2 " série, 8/9, 1996-1997, pp. 422-431.

(36) Ver Maria Feio, Sidonio Paes atravez do coração, Lisboa, Lumen Empresa Internacional Editora, 1921. 
de pacifismo", Maria Feio, depois de descrever emocionada o cenário de dor e de pranto visível na câmara mortuária onde se achavam expostos os despojos mortais do Herói e do Mártir, reconhece o seu principal objectivo: "A bondade é o unico meio de atingir as realidades do ideal humano. Destruir os bons, inutilisar o seu esforço, inverterlhes os méritos pelo odio sectario, victima-los no aniquilamento moral e material é renegar o proprio ideal em nome do qual se praticam atrocidades e injustiças, que cahem como um labeu de oprobrio sobre as nações e as raças onde taes odios mancham a historia e estiolam a beleza de outras virtudes" $\left.{ }^{\prime 37}\right)$. A campanha de todos os exaltados antisidonistas consistia, pois, na negação desse elevado ideal. Sidónio Pais distinguira-se pela bondade, pelo patriotismo e pela bravura, condensando em si as virtudes e os defeitos da raça lusitana, sobre a qual a autora expende umas 'excêntricas considerações étnicas, algo triviais na época. E vai mais longe ao analisar a "personalidade material e espiritual de Sidonio Paes" com base nos estudos fisionómicos de Mantier, concluindo tratar-se de um líder natural, dotado de sólidos atributos de pensador, de emotivo e de enérgico: "Nascera para imperar" $\left.{ }^{\prime\left({ }^{8}\right)}\right)$. A formação do seu carácter ficou, porém, sujeita às influências climatéricas e étnicas e desde logo à acção do clima e à disposição corográfica da região de Caminha, propícia a receber "uma mais directa emanação das instancias solares e astraes" $\left.{ }^{39}\right)$. Marcado pelo ambiente de Caminha até ao despontar da adolescência, respirou depois outro ar "impregnado de belleza e de poesia" na romântica cidade do Mondego. Tornou-se um grande amoroso, mas Maria Feio apressa-se a "purificar" e a "espiritualizar" essa faceta, associando a propensão amorosa de Sidónio ao "seu ideal humanitário" e à sua "alma mystica e ardente". Revelara-se, também, um devoto da arte, apreciador da pintura e melómano praticante a "tocar violino com notavel expressão", além de afável no trato e elegante nas maneiras.

$\mathrm{E}$ a autora prossegue o retrato do seu biografado retocando as partes mais incómodas: o seu passado de livre-pensador foi passageiro e subjugado pela "sua tendencia mystica" e tradicionalista; a sua vaidade era um fenómeno comum na época e atacava "os organismos

(37) Cf. Ibidem, pp. 22-23.

(3i) Cf. Maria Feio, Sidonio Paes atravez do coração, ob. cit., p. 32.

(39) Cf. Ibidem, p. 41. 
nervosos" como o dele, propenso - Maria Feio não ousa negá-lo - a um "impulsivismo arrebatado e violento, que o tornavam colérico, tenaz e absoluto. Quando the voltava a serenidade, lamentava-se d'esse nervosismo irado e assomadiço, que the punha no olhar agudo lampejos coruscantes de terrivel" $\left({ }^{40}\right)$; viera da Alemanha com ideias renovadoras, porque a sua vocação reformadora era profunda e tinha sido eloquentemente demonstrada na Escola Brotero de Coimbra; confrontado com a "desmantelada nau da Pátria" a vogar sem rumo no meio de uma tremenda tempestade, sentiu-se obrigado a desembainhar a espada, embora Ihe repugnasse todo o derramamento de sangue entre irmãos; o seu triunfo militar, conseguido no alto do Parque Eduardo VII, foi dedicado à salvação da Pátria, à semelhança dos valorosos feitos do Condestável D. Nuno Álvares Pereira, seu "ídolo e irmão de armas"; ao tentar promover a prosperidade nacional foi forçado a extirpar o radicalismo da República e a abandonar os seus antigos preconceitos de "libertário", devolvendo ao povo a sua natural religiosidade; animado por uma energia inesgotável, quer como Presidente da República, Ministro dos Estrangeiros e da Guerra, quer depois como Chefe de Estado da Republica Nova dispendeu um esforço hercúleo, dormindo pouco, concentrando as suas forças em todas as reformas e projectos, desdobrando-se em visitas oficiais e em incursões pelos bairros pobres a distribuir consolos e benefícios; e até na sua vida intima foi alvo de "lendas imaginarias e calumniosas", que o davam por separado da legítima esposa, quando, afinal, era da índole inibida e recatada desta manter-se no recato do lar junto dos filhos, não acompanhando por isso "a Esposa nas funcções de Chefe de Estado" $\left({ }^{41}\right)$.

Na parte final do livro, Maria Feio evoca a festa das crianças em Sintra, que havia relatado no seu folheto Patria e Coração, em abono da comovente e insinuante figura de Sidónio Pais, "mais respeitavel que antes e depois de D. Pedro $\left.\mathrm{V}^{\prime \prime}{ }^{42}\right)$. Evoca também as afectuosíssimas relações existentes entre Sidónio e a sua māe, a propósito da célebre e emotiva visita a Caminha. Discorre ainda sobre a influência da hereditariedade materna e paterna no carácter de Sidónio, salientando que o pai apresenta "um typo caracteristicamente arabe", além de que

(40) Cf. Ibidem, p. 75.

( ${ }^{41}$ Cf. Maria Feio, Sidonio Paes atravez do coraçāo, ob. cit., p. 119.

$\left.{ }^{42}\right)$ Cf. Ibidem, p. 134 
pelo seu lado teriam derivado as manifestações de demência que vitimaram dois dos seus filhos (a Ana da Glória e o Aureliano). Conclui com duas notas desconexas: sugere um parentesco de sangue entre Sidónio Pais e D. Nuno Álvares Pereira, esboçado por uma ligeira e fantasiosa pesquisa genealógica; e resume a entrevista conseguida na prisão com o assassino do "Heroe e Martir do Dezembrismo", José Júlio da Costa, que numa final e enternecedora confissão ter-Ihe-á dito: "JuroIhe, minha senhora, que se hoje pudesse dar vida para restituir Sidonio Paes á familia, apartado de luctas politicas, faria saltar os miolos com uma bala" $\left.{ }^{43}\right)$.

Percorremos, com alguma minúcia, o conteúdo da narrativa de Maria Feio por se tratar, em nossa opinião, da mais hagiográfica biografia de Sidónio Pais. Biografia inspiradora ao que parece de A. Cunha Raposo, autor de O Mistério do crime de 14 de Dezembro $\left({ }^{44}\right)$, texto de apologética sensacionalista, publicado talvez no final da década de setenta e que veicula a tese do complot maçónico contra Sidónio Pais, no qual José Júlio da Costa, "tuberculoso e semilouco", foi apenas um dos quatro homens arrigementados pelo Grémio Lusitano e pelo seu grão-mestre Magalhães Lima para assassinar o Presidente da República.

As achegas do Visconde do Porto da Cruz, de Roma Neto e de Homem Christo Filho não igualam o trabalho de Maria Feio porque tendem apenas a valorizar Sidónio Pais durante o seu intenso, mas efémero "consulado", a sua trágica morte, a grandiosa manifestação de pesar nacional que o funeral terá proporcionado e o período subsequente de agitação político-militar.

Roma Neto glorificou o Grande Portuguez através de uma prosa directa, descritiva e sustentada por frases enfáticas, tais como o pretenso murmúrio derradeiro "Morro bem! Salvem a Pátria!", posto por dois jornalistas $\left({ }^{45}\right)$ nos lábios do moribundo ou o desabafo "Portugal

(43) Cf. Ibidem, p. 177.

(44) Ver A. Cunha Raposo, "O Mistério do crime de 14 de Dezembro", in Os Grandes enigmas de entre duas guerras, tomo 1, Lisboa, Amigos do Livro, s.d., pp. 213-254. Ver, em especial, pp. 220-221.

(45) A célebre frase, impregnada da "atmosfera" messiânica que entāo se respirava e reproduzida anos a fio nos mais diversos textos e das mais diversas formas, apareceu incluída numa das "peças" da reportagem de O Sécullo de 15 de Dezembro de 1918, puxada para a primeira página a duas colunas e intitulada "A Tragédia de ontem. O Presidente da República morto a tiro na estação do Rossio". Aí e sob a rubrica "O Chefe do Estado. Morreu no banco do 
era uma nação pequena para um homem tão grande!" (noutra versão: "Era um homem grande demais para um tão pequeno paiz!") atribuído a Thomas Birch, embaixador dos Estados Unidos da América em Lisboa, e pela transcrição integral de documentos probatórios de uma política inteiramente republicana e de uma "grande obra de saneamento" combatida e denegrida pelos seus adversários.

hospital, seguindo o cadáver, de madrugada, para Belém", lê-se a dado passo: "[...] Mal que o automóvel que o conduzia, já ferido, chegou ao hospital de S. José, tendo subido a ladeira que conduz à entrada do Banco, o corpo foi transportado para a mesa da casa das operações e compareceram logo os sis. drs. Damas Mora e Torres Pereira, que estavam de serviço, os quais verificaram que o chefe do Estado dava ainda sinais de vida. - Não me apertem muito, rapazes - dissera ele, ao ser levantado para sobre a mesa. Pouco depois de os médicos examinarem as perfuraçōes produzidas pelas balas, uma das quais penetrou nos pulmões e outra interessou o fígado, o sr. dr. Sidónio Pais tentou ainda levantar-se e disse ao alferes sr. Ferreira da Silva: - Morro, mas morro bem! Salvem a Pátria..." (Cf. O Século, 15 Dez. 1918; e Jacinto Baptista e António Valdemar, Repórteres e reportagens de primeira página. II - 1910-1926, Lisboa, Assembleia da República/Conselho de Imprensa, pp. 140-141). Trabalho de reportagem anónima que uma tradição oral, segundo refere João Medina (Cf. Idem, Morte e transfiguração de Sidónio Pais, ob. cit., pp. 149, 167-168 e 208), atribuiu a Reinaldo Ferreira, o famoso Repórter X, e que na sessāo parlamentar de 8 de Janeiro de 1919, Feliciano da Costa, incompatibilizado com o capitāo Eurico Cameira, ajudante de campo de Sidónio Pais, não hesitou em atribuir a sonora e empolgante frase ao "fecundo invencionismo" do capitão Cameira. Por seu turno, David de Carvalho, na obra Os Sindicatos operários e a repriblica burguesa (1910-1926) (Lisboa, 1977, p. 92), conta que foi Rocha Júnior o inventor da frase: "[...] refere que foi Rocha Júnior, então chefe de Redacção do 'Diário de Noticias' - não contente com a simplicidade com que o seu repórter Adriano Costa relatava o acontecimento -, quem mandara acrescentar o 'Morro bem! Salvem a Pátria!' ao que Sidónio teria proferido no seu último adeus à vida" (Cit. por José Brandão, Sidónio. Contribuição para a história do presidencialismo, Lisboa, Perspectivas \& Realidades, 1983, p. 182). Terá sido assim? Quanto à invenção da frase, o comandante Armando da Silva Pais, sobrinho de Sidónio e o próprio filho deste, dr. Afonso Bessa Pais, por nós entrevistados, foram categóricos, frisando que o Presidente morreu pouco depois dos disparos sem ter balbuciado uma única palavra, nem mesmo o prosaico e nada enfâtico "Nāo me apertem rapazes". A frase "Morro bem! Salvem a Pátria!" fora, pois, inventada e desde 1964 que se acha revelado, em letra de imprensa, como e quem a inventou. Rocha Júnior escreveu um artigo "Frases da Hora Final. $O$ 'Diário de Notícias' também teve a sua" - publicado no suplemento do número 
Homem Christo Filho, repetindo factos e imagens, acentuou o cariz emblemático de Sidónio Pais como "Salvador da Pátria", indelével e sobrevivo às malévolas intençōes "dos aventureiros impuros" que nāo conseguiram impedir a transmissão da "chama salvadora" $\left({ }^{(4)}\right)$.

Da mesma hoste de adeptos o professor de Medicina e Secretário de Estado no último Governo sidonista, João Alberto Pereira de Azevedo Neves, saiu a lume, em 1923, com o artigo Trez Ditadores. Sidonio Pais, Mussolini e Primo de Rivera, texto mal acolhido pelos indefectiveis porque, arrastado pelo seu monarquismo, denunciou, aliás com apodítica lucidez, a tentativa infrutífera de Sidónio Pais construir um partido novo à custa da destruição dos existentes. Erro grave cometido em Espanha por Primo de Rivera que "empreende uma luta contra os partidos, uma guerra tenaz, que parece ser de aniquilação. Erro. Sem politicos não ha estados modernos: o Estado não se governa nem com sabios nem com tecnicos" $\left({ }^{47}\right)$. Erro que Mussolini não cometeu em Itália porque actuou moralizando e reformando os "partidos sem procurar destrui-los" dentro do regime vigente, dentro da ordem estabelecida e, apesar da nítida deriva ditatorial, "triunfou e triunfará; é sua a vitoria". Sidónio foi, pois e apenas, um precursor do erro...

do centenário do Diário de Notícias, ano 101, 29 Dez. 1964, que há muito pouco tempo nos foi referenciado pelo conhecido jornalista, escritor e bibliófilo António Valdemar, a quem agradecemos tão preciosa e ignorada "pista". À luz desta revelação pode, também, reler-se com proveito a crónica de Belo Redondo, "A Morte do Rei", in Grandes repórteres portugueses da I República. Os Casos vibrantes, anedóticos, dramáticos, confidenciais descritos pelos próprios jornalistas que os viveram. Selecta jomalistica, Lisboa, Foto-Jornal Edições e Artes Gráficas, 1986, pp. 51-55. E, por último, se tivermos em conta o depoimento de Luís C. Lupi, Memórias. Diário de um inconformista, 1901 a 1938, Lisboa, Edição do Autor, 1971, pp. 4142, conclui-se que Reinaldo Ferreira preferiu manter, em conversas de café, a versão publicada por O Século para enaltecer as suas qualidades de grande repórter.

( $\left.{ }^{46}\right)$ Cf. Homem Christo Filho, Les Porte flambeaux, Paris, Éditions Fast, [1919], p. 260. O livro foi prontamente saudado pela imprensa conservadora, nomeadamente $A$ Época do conselheiro Fernando de Sousa (Nemo) que lhe consagrou uma página de alto a baixo e a quatro colunas: A Memoria de Sidonio Paes rehabilitada no estrangeiro. Um capitulo dos "Porte-flambeaux", novo livro de Honem Christo, Filho.

$\left({ }^{47}\right)$ Cf. Azevedo Neves, "Momentos politicos. Tres ditadores. Sidonio Pais, Mussolini e Primo de Rivera", Diário de Lisbon, 9 Out. 1923, p. 2. 
Um outro monárquico colaborador da Repíblica Nova à frente do Governo Civil do Porto e que se viu envolvido na conturbada fase subsequente à morte do Presidente e da frustrada tentativa restauracionista no norte, que sofreu "perseguições" e a dolorosa demissão do Exército, o major de Cavalaria Alberto Cardoso Martins de Menezes Macedo, também conhecido por Alberto Margaride, organizou logo que pôde a sua defesa com vista à almejada reintegração, coligindo documentos probatórios da sua inocência. Publicou-os em 1928 num opúsculo sem título e de distribuição irregular $\left.{ }^{48}\right)$. Prosseguiu a tarefa ajudado pelo alferes, demitido na mesma altura, António Pinto Machado $\left.{ }^{49}\right)$. Culminou-a a solo com dois trabalhos de maior fôlego: A Hora da Justiça ${ }^{(50)}$ impresso em 1934, e o inédito O Estado Novo, de Junho de $1946\left({ }^{(51}\right)$. Naquele livro compilou vasta e diversa informação (uma parte dela remete para os dois trabalhos anteriores), nomeadamente artigos avulsos na imprensa que marcam o seu depoimento e a sua posição face a vários acontecimentos políticos. Chamamos sobretudo a atenção para um texto saído em $A$ Monarquia, de 20 de Janeiro de 1920, com o sugestivo título El-Rei D. Carlos e Sidónio Pais e que exprime a sua tese de fundo: D. Carlos presidiu a uma "república de coroa" e o republicano Sidónio reinou como "um monarca de facto"; mas ambos se perderam, porque aceitaram a "organização democrática onde se encontraram, em breve se viram a batalhar sòzinhos no combate glorioso que os fez,

(4 ) Como não tem título citámo-lo pelo nome do autor e pelas primeiras palavras de texto impresso: Alberto Cardoso Martins de Meneses Macedo, [Os cargos civis $e$ militares...], Guimarães, [Edição do Autor], [1928]. Possuímos dois exemplares amavelmente oferecidos pela neta do autor, a estimada genealogista $\mathrm{e}$ investigadora da História Vimaranense D. Maria Adelaide Moraes.

(49) Ver António Pinto Machado, Justiça política. Descriçäo de factos passados nas campanhas ao Sul d'Angola em 1914-1915, assim como dos acontecinentos politicos de 1918-1919. Transcriçño textual dum desenvolvido relatório do Ex.mo Snr. najor de cavalaria Alberto Cardoso Martins de Menezes Macêdo (Margaride) no qual se leem importantes documentos, Guimarães, [Edição do Autor], 1932.

( $\left.{ }^{\circ}\right)$ Alberto Cardoso Martins de Menezes Macedo (Margaride), A Hora da justiça (Maio de 1934), Vila Nova de Famalicão, [Edição do Autor], 1934.

(51) Ver Idem, O Estado Novo. Junho de 1946. Dactiloscrito, [1946]. Existe um exemplar no Arquivo Pessoal de Sidónio Pais [A.P.S.P.] - SubSistema Sidónio Bessa Paes. 
inutilmente, dois grandes mártires da nação" $\left({ }^{52}\right)$. Para Margaride o erro de Sidónio foi principalmente o de se subalternizar a "um partido republicano" - o P.N.R. que Pedro Fazenda e Egas Moniz consideraram "abandonado" pelo Presidente!...-, e de colocar esse partido acima da Nação. Tal como D. Carlos, malogrado "prisioneiro dos partidos"... Este e outros temas reaparecem no algo desordenado "libelo" de 1946. "Libelo" de acusação contra a dualidade de critérios usados pela "nova situação" em relação a um conjunto de oficiais - uns continuaram demitidos apesar dos relevantes serviços prestados ao 28 de Maio, outros tiveram "quem se interessasse a valer" e foram premiados $\left({ }^{53}\right)$.

Ao tópico político da preservação e do engrandecimento da herança sidonista, Alfredo Freitas Branco, no seu livro publicado em 1928 - meio testemunho pessoal de "cadete" idólatra e dedicado, meio "manifesto" em prol do fascismo em Itália, do 28 de Maio de 1926 e da subjacente "organização nacionalista" ${ }^{54}$ - haveria de acrescentar a nítida imagem do Sidónio precursor da ditadura nacional que enterrou a $1^{\text {" }}$ República e, sobretudo, da acção e do pensamento de Benito Mussolini: "O Presidente Sidonio teve, na verdade, uma visão completa do rumo, politico e social, que o futuro tomaria. Antes da realisação do Fascismo na Italia, Sidonio Paes, sentiu-o, pensou-o e tentou realisal-o para Portugal" $\left({ }^{55}\right)$.

O momento era obviamente o mais propício para este tipo de afirmações. A postura ditatorial de Sidónio Pais e algumas medidas promulgadas pelos seus governos "legitimavam" uma imediata comparação com o "auspicioso" modelo transalpino. E em abono de tão tentadora similitude já, uns cinco anos antes, João de Castro Osório, incansável obreiro da doutrinação fascista em Portugal, soubera dar o tom certo. Sidónio Pais e o Sidonismo representavam a emanação positiva de um movimento ditatorial, messiânico, que "vinha de longe, desde a reacção mental de Oliveira Martins passando por Joāo Franco

(52) Cf. Idem, A Hora da justiça, ob. cit., p. 98.

${ }^{(53)} \mathrm{Cf}$. Idem, O Estado novo, trab. cit. Entre outros é referido o caso do alferes António Pinto Machado, pp. 28-29.

(54) À frente dela destacou-se João de Castro Osório, autor do prefácio aos discursos de Sidónio Pais, do Manifesto nacionalista e de A Revoluçāo nacionalista.

${ }^{\left({ }^{5}\right)}$ Cf. Visconde do Porto da Cruz, Paixāo e morte de Sidonio... e o mais que se seguiu... Memorias e apontamentos para a historia, Funchal, Tipografia Esperança, 1928 , p. 80 . 
tentando salvar o regimen mas renovando o seu arcaboiço politico, por Bazilio Telles tentando renovar a Nação por uma revolução vencedora e congregada numa ditadura de realisações. Mas era ainda a ideia profunda, interior lutando contra a ideologia e não a expontanea sintese de forças da Nação" ${ }^{(56)}$. Antes de mais, Sidónio era o Libertador "da desesperança e do mal", sagrado em 8 de Dezembro de 1917, dia de Nossa Senhora, Padroeira de Portugal, o "Desejado, o entusiasmador do povo, mas ao mesmo tempo aquele que pelo seu aparecimento e existencia mostraria o novo caminho" $\left({ }^{57}\right)$, o "verdadeiro messias", o "representante dessas energias profundas, aquele que as tornou conscientes no entusiasmo do seu nome, aquele que iniciou a forma de acção que elas terão de seguir" ${ }^{(58)}$. Sendo a "Ditadura Nacional" uma profunda aspiração messiânica do povo português (o texto de João de Castro é, sem dúvida, uma excelente amostra ideologémica do modo de glosar politicamente o tema mítico do messianismo...) Sidónio Pais, apesar dos seus "preconceitos liberais e republicanos" sinceramente assumidos, mas contrários "ao instinto da sua alma", merecia o epíteto de primeiro Ditador de Portugal, embora só parcialmente por causa dos seus insuperáveis preconceitos de jacobino $\left({ }^{59}\right)$.

Repetindo o mote, António Ferro, no seu famoso livro Salazar, le Portugal et son Chef, teve o cuidado de introduzir Sidónio Pais como "o verdadeiro precursor das ditaduras modernas" $\left({ }^{(0)}\right)$. E a mesma ideia foi pouco depois reproduzida, no Brasil, por Abel Ferraz de Sousa: "A coragem legendária do major Sidónio Paes, escorraçando do galarim os vendilhões da honra nacional e implantando na Europa a primeira ditadura fascista, fôra a primeira arrancada, fôra o primeiro alarme para despertar o espirito viril da nacionalidade, narcotisado,

(56) Cf. João de Castro, "Sidonio Paes e o messianismo ditatorial", in Sidonio Pais, Um ano de ditadura. Discursos e alocuçôes de... Coligidos e ordenados por Feliciano de Carvalho com um estudo politico de Joño de Castro, Lisboa, s.n., 1924, p. 27.

(57) Cf. Ibidem, p. 14.

(5s) Cf. Ibidem, p. 15.

$\left({ }^{9}\right)$ Cf. Ibidem, p. 31.

$\left.{ }^{(60}\right)$ Cf. António Ferro, Salazar, le Portugal et son Chef, Paris, Grasset, 1934, p. 73. Sobre a juventude sidonista de António Ferro ver Ernesto Castro Leal, António Ferro. Espaço político e imaginário social (1918-32), Lisboa, Edições Cosmos, 1994, pp. 45-47. 
permitam-me dizê-lo, bestialisado mesmo, durante tão longos anos de desmandos e crimes de toda a sorte" $\left.{ }^{\prime 61}\right)$.

A tese estava, pois, esboçada do ponto de vista ideológico-político e mítico-simbólico, encantando todos quantos se haviam rendido à onda fascista que galvanizava a Europa mediterrânea e alguns dos seus antigos domínios coloniais. A imagem de um Sidónio precursor do fascismo era, então, um acto de propaganda pertinente e eficaz, "agarrada" oportunisticamente pelos apologetas da "Revolução Nacional" e do Estado Novo salazarista( ${ }^{(2)}$ ), a que poucos pareciam resistir.

António Manuel Pereira considerou a actuação política de Sidónio Pais demasiado branda para com a permanente agitação revolucionária, ficando muito aquém da firmeza e da determinação de Salazar( $\left.{ }^{(3)}\right)$.

(61) Cf. Abel Ferraz de Sousa, Quem é Salazar? Ecos da Revoluçäo Nacional que se tomou conhecida pela "Revoluçăo de 28 de Maio de 1926", São Paulo, Edição do Autor, 1936, p. 14.

${ }^{\left({ }^{2}\right)}$ Eis alguns textos ilustrativos: Capitão David Neto, Dôa a quem doer, Porto, Livraria Tavares Martins, 1933, pp. 71-72; “Na União Nacional. Um notavel discurso politico do sr. Presidente do Conselho. Projectos grandiosos e comemorações patrioticas. Um arco triunfal á memoria de Sidonio Paes", Diário de Notícias, 5 Dez. 1935, pp. 1 e 6; "Os Precursores do Estado Novo. O Exercito concentrando-se em volta da prestigiosa figura do presidente Sidonio Paes estabelece a segunda ditadura militar, novo anceio de libertação nacional contra a política facciosa dos partidos", O Século. Número especial, 28 Maio 1936, p. 5; "Um Português maior que jàmais será esquecido", Portugal Maior. Grande revista mensal, Lisboa, 1, Mar. 1937, p. inum.; Leopoldo Nunes, Carmona (Estudo biográfico), Lisboa, s.n., pp. 49-50; e [Leopoldo Nunes e António Leitão], Os Grandes obreiros da revolução nacional, Lisboa, Editorial Obreiros, 1950 (fasc. 1 incompleto - Sidónio Pais, pp. 15-32). Há também exemplos claros da colagem do Estado Novo a Sidónio Pais e ao Sidonismo, repetida mesmo quando aquele já se abeirava do seu fim: ver alguns artigos (visto que nem todos insistem na mesma "tecla"...) publicados pelo jornal O Caminhense (número de 21 de Abril a 5 de Maio de 1972 e número de 21 de Abril de 1973) a propósito das comemorações centradas fundamentalmente em Caminha e que são objecto de análise em Armando B. Malheiro da Silva e António Júlio Limpo Trigueiros, Sidónio Pais. De Caminha no Panteão Nacional. Retalhos ideológico-políticos, históricobiográficos e genealógicos da memória, Viana do Castelo, Centro de Estudos Regionais, 1998; e ainda Manuel Busquets de Aguilar, "Páginas de memórias. Sidónio Pais", Roteiro de Viana, Viana do Castelo, ano 13, Ag. 1971, pp. inum.

${ }^{\left({ }^{63}\right)}$ Ver António Manuel Pereira, Do Marquêes de Pombal no Dr. Salazar, Porto, Manuel Barreira, s.d., p. 233 ss. 
Por seu turno, Bruno de Montalvāo, no opúsculo Perfil de Sidónio Pais. Aprecinções pessonis e políticas, impresso em 1942, demarcou-se nitidamente das anteriores "colagens", surgindo aí um retrato desenhado a "contra-corrente": "A grandeza da personalidade de Sidónio Pais - do diplomata e do patriota insigne que pouco antes deixara Berlim em demanda da Pátria - está definida nas suas palavras. Não era um antiliberal, como muitos supunham ou fingiam supôr maliciosamente; não pretendia aniquilar a Rèpublica, conforme insinuavam os seus inimigos; não era um tirano, embora tivesse de adoptar medidas enérgicas para restabelecer a ordem e garantir a autoridade e a paz entre os portugueses de boa vontade, que tinham por aspiração máxima viver do produto honrado do seu trabalho" $\left({ }^{(4)}\right)$.

No mesmo ano em que saiu a público esta representação apologética, mas defensiva e sóbria, de Sidónio Pais, Teófilo Duarte, seu antigo companheiro no Parque Eduardo VII e futuro colaborador de Salazar, deu ao prelo um trabalho de fôlego, com hábeis retoques de estudo histórico, a ponto de Oliveira Marques, considerar o livro Sidónio Pais e o seu Consulado "bastante mais sério e completo" ${ }^{(5)}$ que as Menorias sobre Sidonio Paes de Rocha Martins.

O livro de Teófilo Duarte, editado em plena II Guerra Mundial( $\left.{ }^{(6)}\right)$, foi concebido como um estudo pormenorizado, interpretativo e justificativo (o autor considera e tenta demonstrar através de uma breve retrospectiva histórica que o "golpe de força" é o processo tradicional empregue sempre pelos portugueses para resolverem as suas graves crises políticas) da "revolução dezembrista", surgida após "seis anos de República", de "Esperanças, desilusões, erros e crimes". Um estudo sobre o prestígio pessoal de Sidónio Pais, embora

(6.4) Cf. Bruno de Montalvāo, Perfil de Sidonio Pais. Aprecinções pessoais e políticas, Lisboa, Edições Expansāo, 1942, p. 12.

(65) Cf. A. H. de Oliveira Marques, Guia de história da $1^{a}$ Repuiblica portuguesa, ob. cit., p. 482.

(66) Na última página de texto lê-se: "Concluido a 5 de Dezembro de 1941". E no início de 1942 estava impresso e pronto a ser distribuído pelas livrarias de todo o país, merecendo da imprensa uma ampla e favorável cobertura, confirmada pelos recortes de imprensa colados num "Album" do Arquivo Pessoal de Teófilo Duarte, que pudemos consultar e de onde reproduzimos documentação (nomeadamente cartas, apontamentos'vários, etc.) por inexcedivel gentileza de seu filho, Dr. Teófilo de Castro Duarte. 
muito parco em detalhes biográficos $\left({ }^{67}\right)$ e, também, sobre as várias facetas da política sidonista, em matéria constitucional, religiosa, financeira, económica, social e num conjunto variado e avulso de medidas promulgadas febrilmente no Diário do Governo. Baseado numa farta recolha de fontes ("os jornais da época, as revistas da especialidade, a legislação publicada, os depoimentos verbais de contemporâneos que acompanharam os acontecimentos, e as minhas reminiscências pessoais" $\left(^{(B)}\right)$ ) e escrito num estilo vivo e empolgante. Combinando a heurística histórica e o depoimento memorialístico, patenteado no penúltimo capítulo sobre a conturbada fase subsequente à morte de Sidónio (a agitação político-militar das Juntas, a debilidade do governo sidonista de Tamagnini Barbosa, o restauracionismo monárquico, o retorno dos democráticos à esfera do Poder...), durante a qual o autor foi um activo e controverso protagonista, Teófilo Duarte produziu uma obra que agradou imenso a nostálgicos sidonistas como Domitila de Carvalho, conforme a impressão vertida num depoimento sincero que denuncia, ao mesmo tempo, a profunda parcialidade da dita obra $\left({ }^{(99}\right)$. Arrancou ainda palavras de apreço ao famoso caudilho

${ }^{(67)}$ Num livro de 374 páginas resumem-se a quase duas (pp. 162-164) a sinopse biográfica de Sidónio Pais!... Esta estranha opção de escrever sobre o sidonismo (1917-1918) sem aprofundar as origens, a formação e a trajectória existencial do seu fautor (1872-1918), não foi bizarria exclusiva de Teófilo Duarte, antes se tornou, como temos visto, prática comum e natural, persistindo em estudos históricos recentes.

${ }^{(6)}$ Cf. Teófilo Duarte, Sidónio Pais e o seu consulado, Lisboa, Portugália, [1941], pp. 15-16.

$\left.{ }^{(9}\right)$ Não deixam, de facto, dúvidas as efusivas palavras da professora Domitila: "'Sidonio Pais e o seu Consulado' é um livro [...] de Historia admiravelmente documentada, de Politica vista sob varios aspectos, de literatura porque até como obra literaria é de indiscutivel valor. É finalmente um livro de sentimento pelo coração que transborda em todas as suas páginas, pela ternura inexcedível, em que o seu autor envolveu a memória do seu grande amigo, refere os seus actos de bondade, que lhe grangearam o nome de Santo alem de Heroi e as qualidades misteriosas que faziam dêle o sugestionador máximo das multidões, que sem o sentir o seguiam e o aclamavam. E para aquêles que mantêm intacto o culto por Sidónio Pais, se é um grande prazer evocar as horas de triunfo, que viveu, não é menos consolador recordar a dolorosa e justa apoteose da sua morte. Tudo isso devemos ao admiravel livro de Teófilo Duarte, nome que nunca poderá separar-se do nome glorioso de Sidonio Pais" (A.P.T.D. - Sidonio Paes e a seu Consulado. Correspondencia sobre o livro). 
monárquico, o irriquieto Paiva Couceiro, que em carta de 4 de Fevereiro de 1942 declarou, apesar das naturais discordâncias: "[...] Escreve Historia a sua obra. Pinta muito bem o ambiente, ou antes, o chaos da epocha, - a efervescencia revolucionaria, o partidismo irrequieto, as feiçoes particulares de cada agrupamento politico. Faz justiça ao Integralismo. Põe em fóco, com clareza, a actuação sidonista, sempre resoluta, e, muitas vezes oportuna e feliz, em face de tão enormes dificuldades, sociaes, economicas, e financeiras e, parallelamente, sob o aspecto politico, as ideias do Chefe. A descripção do combate de 5-6 de Dezembro faz vibrar as cordas da emoção heroica. Leitura, em resumo, de bom proveito para todos, e particularmente para mim, forçado ausente durante alguns d'esses acontecimentos" $\left.{ }^{\prime 70}\right)$. E conseguiu também a simpatia dos integralistas pela pena de Pequito Rebelo ou de Alberto de Monsaraz, gratos especialmente, na expressiva opiniāo de Pequito Rebelo, por duas coisas: "a justiça que faz ao Integralismo, e o prazer imenso que me deu e a todos que tenham o coração militar, com a narrativa singela das suas cavalgadas da Revolução de Dezembro" $\left.{ }^{71}\right)$. Mas, compreensivelmente, irritou bastante Norton de Matos, guerrista obstinado, que na folha de guarda em branco do seu exemplar registou, como lhe era habitual, uma cáustica e amarga nota de leitura( $\left.{ }^{(2}\right)$.

$\left({ }^{70}\right)$ A.P.T.D. - Ibidem.

$\left({ }^{71}\right)$ A.P.T.D. - Ibidem, carta escrita em Lisboa e datada de 21-II-42.

(72) Uma nota que ilustra bem como passados algumas décadas as feridas abertas pela luta política nos idos de 1917-1918 continuaram abertas e vivas: "É este mau livro uma prova da desorientação e dos odios que uma propaganda deleteria, com propositos de caracter internacional, por um lado, e clerical, por outro, ambos os lados unidos para o mesmo fim, semeou tão abundantemente em Portugal. Nele se fazem afirmações as mais injustas. É uma constante deturpação da verdade. Acabada a sua leitura, peguei nas "Viagens na minha terra", de Garret, para lavar qualquer mau efeito que me ficasse do atropelado da linguagem que lêra, e nesse delicioso livro encontro as seguintes palavras que, com uma pequena alteraçāo, me permitem condensar o juiso que faremos deste anti-patriotico livro: 'Tão pequeno, tão mesquinho, tāo insignificante, tão desproporcionado á epoca historica a que se refere que, como todas, tem defeitos, mas, como poucas, tem grandeza, é este livro como se nāo existissé. O livro passou; a epoca ficará. Janeiro, 1942" (Biblioteca e Arquivo Pessoal do general Norton de Matos [A.P.N.M.], Ponte de Lima - Teófilo Duarte, Sidónio Pais e o seu consulado (por catalogar)). 
O severo e redutor juízo de Norton de Matos passa ao largo do grande impacte que a tese central do livro de Teófilo Duarte teve no oposto campo político-partidário, na literatura ou, mais precisamente, na feitura do romance Le Prête Jean (1952) pelo escritor e académico francês Pierre Benoit(73) e na produção historiográfica. Redigido claramente da frente para trás, esse livro destila uma opinião exposta como irrefutável: "O regime inaugurado pelo Sidonismo antecederá de cinco anos o imposto à Italia pelo fascismo, e será o precursor de todos os governos de autoridade que, anos depois, proliferariam pela Europa inteira" $\left({ }^{74}\right)$. Mais ainda: a "República Nova" prefigurou a criação de um Estado autoritário, corporativo e concordatário!... Quem não reconhece aqui a hipótese sustentada por Villaverde Cabral e por outros autores atrás citados sobre a feição proto-fascista do sidonismo? E se dúvidas houver basta, talvez, destacar a seguinte passagem: "A situação ia-se agravando dia a dia entre o partido de características pé de boi, e o chefe voluntarioso, a quem o seu apurado instinto e as circunstâncias que tinham surgido, impeliam para rumos então desconhecidos, mas que seriam os do futuro da Europa, nas suas expressões de fascismo e nazismo que ainda estavam em embrião". Ao reler passagens como esta, Alfredo Barroso reforçou, por certo, o seu alento para juízos lapidares numa recente crónica bem cerzida $\left({ }^{75}\right)$.

(73) Ver Pierre Benoit, Le Prête Jean, Paris, Albin Michel, 1952; João Medina, Morte e transfiguração de Sidónio Pais, ob. cit., p. 173; duas cartas de Pierre Benoit para Teófilo Duarte (uma de 12 de Setembro de 1948 e outra de 23 de Novembro do mesmo ano) transcritas por Armando Barreiros Malheiro da Silva, Sidónio $e$ sidonisno. Histórin e mito, vol. 1, dissert. cit., p. 78; e ainda o artigo "Como o grande escritor e académico francês Pierre Benoit reconstituiu a morte de Sidónio no seu romance 'Le Pêtre Jean'”, Diário da Manhä, Lisboa, 14 Dez. 1953, pp. 1-2.

$\left({ }^{74}\right)$ Cf. Teófilo Duarte, Sidónio Pais e o sen consulado, ob. cit., p. 183.

(75) Aí se lêem tiradas como esta: "Sidónio é a primeira irrupção do messianismo político na Europa do século $X X$, a primeira intuição de um conjunto de aspiraçōes, o primeiro protesto do instinto, o primeiro sobressalto das forças elementares contra o racionalismo, a primeira reaç̧ão contra a democracia parlamentar e a filosofia liberal inspiradora dos regimes democráticos, o primeiro herói salvador, o primeiro chefe autoritário que indica o novo poder do Estado nacional. É, em suma, o primeiro afluente do fascismo, uma antecedência, um sintoma precursor dos movimentos ditatoriais da Europa após a Grande Guerra" (Cf. Alfredo Barroso, "Sidónio Pais. O Artilheiro de Deus", in Idem, Janela indiscreta. Diários, crónicas e retratos, Lisboa, Quetzal Editores, 1994, p. 203. Saiu inicialmente no Público Magazine de 15 de Julho de 1990, p. 32). 
Teófilo Duarte, citado, aliás, explicitamente por Barroso, deixou, como se vê,, "pistas" de actual pertinência... E deixou mais duas significativas notas no seu agiomamento sidonista. Sidónio trouxera da Alemanha - afirma convicto - arreigados conceitos de autoritarismo, que combinou com o princípio presidencialista e com as "novas ideias" dos integralistas pretensamente difundidas por Martinho Nobre de Melo junto do Presidente da República Nova $\left({ }^{76}\right)$. E insinua, afinal, que a fórmula presidencialista era o "figurino já consagrado e aceite no mundo político, ao abrigo do qual faria passar um certo número de inovações", ou seja, permitir-lhe-ia impor-se como "chefe dum governo forte, independente de votações parlamentares, autoritário" $\left({ }^{7}\right)$.

Ao filiar Sidónio Pais e o Sidonismo no modelo fascista, Teófilo Duarte comprometeu-os irremediavelmente com o incerto destino desse coruscante modelo: se o Eixo vencesse a guerra mundial em curso Portugal podia associar-se à vitória, exibindo, entre os trunfos históricos recentes, a obra pioneira do "herói" do 5 de Dezembro; mas se saísse derrotado, a política sidonista ficaria à mercê de um inevitável descrédito. Por excesso de fervor anti-democrático, a figura e a acção de Sidónio Pais caíram num beco sem saída, ficando ainda mais à mercê da detracção...

\section{Os Detractores}

Estes começaram a manifestar-se logo após o golpe de Dezembro e incluíram não apenas os democráticos de Afonso Costa e os evolucionistas de António José de Almeida, culpabilizados pelas graves consequências económicas e sociais da política intervencionista adoptada em 1916, mas em pouco tempo os próprios unionistas de Brito Camacho, que de inspiradores e apoiantes passaram a adversários da situação. Na imprensa e apesar do restabelecimento da Censura em Abril de 1918 tinham eco os primeiros ataques contra o novo "homem forte" da política portuguesa: Sidónio Pais deixara-se seduzir pela miragem do poder pessoal; dera azo a um excessivo militarismo; entregara a República na mão dos monárquicos; improvisara perigosamente ao propor uma República Nova de contornos de todo indefinidos; etc., etc.

(76) Cf. Teófilo Duarte, Sidónio Pais e o sen consulado, ob. cit., p. 196.

(7) Cf. Ibidem, p. 191. 
A par destas e de outras críticas lançadas do campo republicano, os monárquicos e integralistas, tidos na gíria da época por conservadores, năo se inibiram de formular inquietações e reservas.

Eduardo Burnay $\left({ }^{(78}\right)$ redigiu em Janeiro de 1918 uma espécie de "carta-aberta" $\left({ }^{79}\right)$ ao "inclito e invicto restaurador da ordem", completada posteriormente por um sentido panegírico intitulado Um ano depois... a Morte! $\left({ }^{(0)}\right)$. Na "carta-aberta" de Janeiro há, entre outras, algumas referências intencionais a Napoleão Bonaparte - o corsego que de militar ao serviço da I República francesa chegou a Imperador da França e senhor de um vasto domínio imperial do Atlântico à Ásia, tendo sido, por isso, comparado a Sidónio Pais pelo Arcebispo de Évora D. Augusto Eduardo Nunes em discurso proferido aquando da visita presidencial a essa cidade em 15 de Fevereiro $\left({ }^{81}\right)$. Burnay louvou a coragem de Sidónio ao expulsar os democráticos ou afonsistas da esfera do Poder, mas não escondeu a sua apreensão a propósito dos indefinidos contornos ideológicos e político-institucionais da proclamada República Nova. Com efeito, era, no mínimo, embaraçoso o apoio dos monárquicos a uma República ordeira, mas... republicana! A solução proposta por Sidónio parecia tombar num equívoco e num abismo. E Alfredo Pimenta apontou-o, sem rodeios e à guisa de premonição, numa conferência proferida na Liga Naval em 26 de Fevereiro de 1918: "Esta Republica Nova tem um ambiente conservador e tem por cooperadores os elementos monarquicos. É, por consequencia, uma republica de caracter paradoxal, contra a qual os verdadeiros republicanos se apresentam em acto de hostilidade, não tendo ainda entrado no caminho das violencias, porque teem

$\left({ }^{78}\right)$ Para uma abordagem prosopográfica deste e dos autores que se seguem, bem como dos companheiros de armas, colaboradores, adeptos e adversários de Sidónio Pais deve ver-se com proveito as notas dos vários estudos monográficos de João Medina e, em especial, as notas do seu livro, Morte e transfigutraçāo de Sidónio Pais, ob. cit., pp. 147-221.

${ }^{(7)}$ [Edurado Burnay], Sete anos depois... A Republica nova. Carta ao sr. Sidonio Paes, inclito e invicto restaurador da ordem, Lisboa, Lamas Mota e Ca, s.d.

$\left({ }^{(s 0}\right)$ Idem, Um ano depois... a Morte! (Carta ao Diório de Notícias), Lisboa, Tipografia Universal, 1918.

(ii) Ver resumo em João Medina, Morte e transfigutração de Sidónio Pais, ob. cit., pp. 174-175. 
medo; mas fal-o-hão, quando virem que o Sr. Sidonio Pais enfraquece" $\left.{ }^{32}\right)$.

Um equívoco fatal denunciado, também, por António Sardinha nas páginas do jornal $A$ Monarquia, diante do féretro do malogrado Presidente: "Montou Sidonio Pais um dia a cavalo e, rapidamente, eilo transitando duma penumbra mais que discreta para os destaques ruidosos da notoriedade. Logo um equivoco lamentavel se estabeleceu e esse equivoco levou Sidonio Pais á sepultura. [...] A tara da Republica é o demagogismo e a Republica não se melhora, senão destruindo-se. Tentou melhoral-a Sidonio Pais. Com isso não fez mais do que armar o braço que o abateu. Até na sua morte Sidonio Pais morreu republicano" $\left.{ }^{83}\right)$.

A mesma ideia seria, aliás, glosada pelo monárquico constitucionalista Luís de Magalhães a abrir a sua "defesa" intitulada Perante o Tribunal e a Naçāo( ${ }^{\left({ }^{4}\right)}$, bem como na extensa análise política de Anselmo Vieira, com um capítulo consagrado à República Nova e ao seu mentor, escrito para "desfazer parvoices" e reduzir a acção de Sidónio às suas merecidas proporções. Vieira critica, por isso, "quem, movido a rebates de lisonja, ou impellido pela audacia da ignorancia, comparasse ao grande Napoleão o pequeno mas bem intencionado Sidonio Paes" $\left({ }^{85}\right)$ e indigna-se por se ter chegado a "bacorejar que $o$ chefe da republica nova, não querendo inaugurar a dynastia sidonica, ficaria muito lisonjeado, se D. Manuel II, restituido ao throno de seus antepassados, lhe concedesse um titulo de Duque e sufficientes meios para manter o prestigio da honraria" $\left.{ }^{(6)}\right)$. Somando páginas de miúda apreciaçāo da frustrada e frustrante acção sidonista, assevera, em jeito de remate final, que Sidónio Pais foi deificado e posto num pedestal

$\left.{ }^{(22}\right)$ Cf. Alfredo Pimenta, A Situaçāo política. Conferencia realisada no Salâo Nobre da Liga Naval Portuguteza, na noite de 26 Fevereiro de 1918, Lisboa, Livraria Ferreira, 1918, p. 32.

("3) Cf. António Sardinha, "E agora?", in Idem, Na feira dos mitos. Idéas \& factos, Lisboa, Livraria Universal de Armando J. Tavares, 1926, pp. 277-278.

(\$4) Ver Luis de Magalhães, Perante o tribunal e a nação. A Monarchia do norte e o julganento da Junta Governativa do Reino, Coimbra, Coimbra Editora, 1925, pp. 13-19.

$\left({ }^{5}\right)$ Cf. Anselmo Vieira, A Crise nacional, Lisboa, J. Rodrigues \& C", 1926, p. 408 .

("si) Cf. Ibidem, p. 408. 
superior às suas capacidades intelectuais e políticas, vaticinando, por isso, que se tivesse sobrevivido ao atentado "seria desastrosa a sua queda" $\left({ }^{87}\right)$.

Por seu turno, o médico setubalense Fernando Garcia, sem conseguir disfarçar um forte anti-jacobinismo e nítido monarquismo, refugiou-se em alguns testemunhos e nos ensinamentos da ciência do seu tempo - sem paralelo com António Aurélio da Costa Ferreira ${ }^{(8 s)}$--, pegou no bisturi e predispôs-se a dissecar o caso. Servido por uma base biográfica lacunar, pobre e salpicada de imprecisões graves $\left({ }^{89}\right)$ - a ausência de uma biografia exaustiva e rigorosa de Sidónio Pais atravessará, aliás, este século com prejuízo manifesto de todos os ensaios interpretativos até agora conhecidos... -, confessou-se fascinado pelo "estado de alma collectivo formado em torno do presidente Sidonio Paes", que considerou "um dos phenomenos de psychologia collectiva mais interessantes que se teem dado em Portugal" $\left({ }^{90}\right)$, e esboçou uma análise estribada na formação jacobina e positivista recebida em Coimbra, nas implicaçōes da escolha que o maçon Sidónio fizera, para nome simbólico, de Thomas Carlyle e na metamorfose vivenciada em Berlim, onde absorvera o germanismo, o militarismo e a propensāo ditatorial. A conclusão essencial é óbvia: típico herói carlyleano, republicano seduzido pelas fórmulas monárquicas, incapaz, porém, de se empenhar numa verdadeira política conservadora dado o seu estigma revolucionário, Sidónio Pais não deixou uma obra política válida, mas uma herança simbólica de indelével significado: "A belleza que o pôvo informou numa lenda dourada, mystica e sentimental, que cerca com um nimbo de poesia terna e'saudosa, essa ultima flôr de

(77) Na remota hipótese de sobreviver: "Continuaria a assegurar a ordem nas ruas; depuraria de vadios, assassinos e ladrões as principaes cidades; manteria a liberdade de consciencia, mas não effectuaria nenhuma reforma de vulto em qualquer das tres ordens sociaes, porque nāo tinha pessoalmente as condições para o fazer, nem soube ou não poude cercar-se de collaboradores que the suprissem as deficiencias" (Cf. Ibidem, p. 437).

(s") Ver António Aurélio da Costa Ferreira, "O Dr. Sidonio Pais. (Ensaio de ethologia)", Revista de Historia, Lisboa, ano 9, (33-36), 1920, pp. 69-70.

("9) Fernando Garcia, Sidonio Paes. Um Ensaio de psychologia politica, Setubal, Associação Setubalense de Caridade, 1921. Ver o elenco de erros assinalados por Armando Barreiros Malheiro da Silva, Sidónio e sidonisno. História e mito, vol. 1, dissert. cit., p. 82.

(') Cf. Ibidem, p. 5. 
Cavallaria, que surgiu na bôa terra Portuguesa, onde se redigiu a primeira historia de Amadis, o lendario reparadôr de aggravos e endireitadôr de tortos, em que germina talvez já uma ideia fundamente arreigada na consciencia nacional: o messianismo, que a faz esperar persistente e pacientemente o seu Desejado, galopando vagamente numa athmosphera nevoenta" $\left({ }^{91}\right)$.

Aos olhos dos monárquicos e dos integralistas era naturalmente agradável esta maviosa percepção de um intenso messianismo, tipicamente português, projectado na figura cavaleiresca de Sidónio Pais, assim como lhes eram caras a defesa da ordem, a perseguição aos "democráticos" ou a atitude de pendor neutralista face à Grande Guerra.

No entanto, para os adeptos ferrenhos da intervenção militar de Portugal no front e do retorno ao Poder dos partidos da "República Velha" o "consulado sidonista foi um equívoco político de graves consequências", segundo a expressiva síntese do artigo anónimo publicado no suplemento Extra do jornal A Capital, de 5 de Dezembro de 1969.

A questāo do C.E.P. e da conduta de guerra gerida pelos governos de Sidónio Pais animou um debate público - frisámo-lo já a propósito da contra-ofensiva de Cunha e Costa - determinado mais por razões de ideologia e de estratégia política que por um exclusivo apuramento da "verdade histórica". Em Paris, a Ligue pour la Défense de la République Portugaise à l'Étranger, composta por figuras cimeiras da "equipa de guerra", como Bernardino Machado, João Chagas ou Alexandre Braga, editou o opúsculo La Vérité stur le Portugal((22) e o exPresidente da República, deposto pelo golpe dezembrista, expende aí, tal como reproduz na colectânea de notas e de documentos avulsos intitulada No Exílio $\left({ }^{13}\right)$, a ideia de que a revolução sidonista culminou um processo urdido pelos sectores germanófilos para, através da deposição do governo de Afonso Costa, aniquilarem por completo o

(') Cf. Ibidem, pp. 56-57.

(92) Ver [Bernardino Machado], La Vérité sur le Portugal, Paris, Ligue pour la Défense de la République Portugaise à l’Étranger, 1919.

('3) Ver Idem, No Exílio, Famalicão, Tipografia Minerva, 1922, nomeadamente pp. 87-105 (texto intitulado O Perigo alemāo en Portugal. Proclantação). 
esforço militar português no teatro europeu. E em abono desta contundente afirmação aponta várias medidas da governação sidonista que sugeriam uma diferente orientação das autoridades de Lisboa: o Estado Maior do C.E.P. formado por oficiais experientes e empenhados na "causa da guerra" foi entregue a quem não reunia os requisitos adequados; o corpo de aviação a operar em conjunto com a força aérea francesa foi dissolvido e integrado no C.E.P.; o "comunicado português de guerra" foi suprimido e a censura agravada no sentido de "abafar" textos de apoio ao intervencionismo português; e a dissolução, por decreto, do Museu da Grande Guerra, criado pelo governo anterior, ilustrava plenamente os preconceitos anti-guerristas dos novos governantes. Mas estas e outras medidas deixam, também, perceber uma diferença óbvia quanto à autonomia e à importância do efectivo português no quadro das forças aliadas: Norton de Matos e a "equipa de guerra" conferira-Ihe um estatuto elevado, mais próprio de uma potência beligerante equiparável, técnica, financeira e militarmente, à Inglaterra ou à França, enquanto Sidónio Pais e seus colaboradores, herdeiros de uma situação consumada, contra a qual muitos deles haviam proposto a neutralidade, optaram por uma assunção discreta e realista dos compromissos assumidos, especialmente com a "velha Aliada". Dois diferentes "modos de estar" no front que os guerristas converteram habilmente num conflito insanável entre o bem e o mal.

Uma boa conduta de guerra, de acordo com a argumentação de Paulo Osório, era tudo menos germanófila e defectista, ou seja, teria efectuado o roulement das tropas, concederia as licenças estipuladas, manteria o corpo de aviação e recusaria a redução do C.E.P. a uma única divisão militar. O contrário disto era "O Desastre" - título do seu segundo artigo n'A Capital de 12 de Março de 1919, precedido por "Portugal na guerra", publicado no dia anterior. Era, enfim, o enfraquecimento do C.E.P., a trágica derrota no Lys e uma humilhante subalternização de Portugal nas negociações da Conferência de Paz.

A toada crítica estava pronta a ser repetida onde mais conviesse. No Parlamento, Leote do Rego, deputado democrático e antigo comandante da Divisão Naval de Lisboa, dava o seu contributo para o "processo do sidonismo", lembrando que Portugal entrara na guerra a pedido da Inglaterra e em auxílio dos Aliados, que o C.E.P. funcionou em pleno até à situação dezembrista e que, em Lisboa, os governos sidonistas fizeram o jogo das forças monárquicas, reaccionárias e germanófilas, em conluio indecoroso com a propaganda 
e a espionagem alemãs. Reclamava, por isso, um inquérito parlamentar e a indispensável publicação do Livro Branco atrás referido, numa palavra, o julgamento político dos factos e da alegada traição de Sidónio Pais, para o qual o deputado evolucionista (o partido de António José de Almeida secundara, como se sabe, a política de guerra, embora longe da unanimidade...) Eduardo de Sousa, director do jornal República, Iançara mais umas "achas para a fogueira" através do seu discurso na sessão da Câmara dos Deputados de 27 de Junho de 1919, publicado com o título O Dezembrismo e a sua política na guerra ${ }^{\left({ }^{4}\right)}$ e que inclui dados coligidos pelo órgão do seu partido durante 1918 e alguma documentação oficial "escolhida" para reforçar as suas teses políticas. O precedente tinha sido, aliás, aberto com a publicação na imprensa do memorando inglês de 10 de Outubro de 1914 convidando Portugal a colaborar no esforço de guerra, o que se entendia ser um convite formal da Inglaterra para a entrada no conflito e a refutação de que Portugal "se fizera convidado". Aceder a provas documentais $\left({ }^{95}\right)$ será, a partir de então, um dos trunfos de peso na pendulação vitoriosa do debate.

Augusto Casimiro, combatente nas trincheiras, admirador de Norton de Matos e responsável pela organização do Livro Branco, entrou, como já sublinhámos, na polémica fomentada por Cunha e Costa, através de um conjunto de artigos saídos no jornal $A$ Vitória, entre final de Julho e inícios de Outubro de 1919. Reunidos pouco depois em livro $\left({ }^{(\%)}\right)$, recheado de documentos e acrescido de uns incisivos depoimentos emitidos por outros soldados, "todos camaradas e irmãos nas amarguras e nas alegrias dolorosas da Flandres" $\left.{ }^{\prime 7}\right)$. Um deles, 0 moderado António Granjo, soube sintetizar o lema que uniu, desde o

(9.1) Ver Eduardo de Sousa, O Dezembrismo e a sua politica na guerra. (Para a historia do Dezembrismo). Depoimento duma testemunha, Porto, Companhia Portuguesa Editora, 1919.

${ }^{(95)}$ Por causa da publicação no jornal A Noite de um documento considerado confidencial o jornalista e indefectivel republicano guerrista, Bourbon e Meneses, sofreu o vexame da prisão em 1920. Ver Biblioteca Nacional [B.N.] -.. Espólio Bourbon e Menezes, dossier Questão do Documento, que inclui recortes de artigos publicados em outros jornais sobre o caso.

(96) Ver Augusto Casimiro, Sidónio Pais. (Algumas notas sobre a intervenção de Portugal na grande guerra), Porto, Livraria Chardron, 1919.

$\left({ }^{97}\right)$ Cf. Ibidem, p. 335. 
unionismo ao democratismo afonsista, a campanha anti-sidonista: "O sidonismo baldeou a Nação como uma tempestade baldeia uma fôlha. As prisões atulharam-se; fez-se o espírito de ódio e retaliação; dividiram-se as classes e os homens; reduziu-se a opinião pública ao critério policial; consagrou-se a delação; cultivou-se a violência; animaram-se os sentimentos de cobardia e defecção; e, quando estávamos em guerra com país estrangeiro, refreou-se a impulsividade heróica da raça. O sidonismo foi, sob o ponto de vista interno, a aliança com os monárquicos; sob o ponto da guerra, a aliança com os germanófilos. A primeira aliança só podia conduzir-nos a êste resultado - a restauração monárquica; a segunda só nos podia trazer esta consequência - a derrota. Efectivamente, a monarquia foi restaurada no Pôrto; efectivamente, sofremos o desbarato de la Lys" $\left.{ }^{\prime \prime}{ }^{(8)}\right)$. Era, pois, isto que importava repetir até à exaustão, ajeitando-se as "provas" e acentuando patrioticamente a tal diferença subjectiva entre uma boa e uma má conduta de guerra.

Augusto Casimiro não escondeu, aliás, no seu libelo, que o grande erro de Sidónio Pais, a quem não ousa mimosear de "germanófilo", foi o de dar cobertura a uma política fraca: "O govêrno dezembrista passou a vida a concordar com os outros. O êrro da sua política internacional é o de uma pavorosa abdicação perante a política inglesa. Por ele pagará na história, sr. Cunha e Costa..." $\left({ }^{(\$)}\right)$. De facto, pagou e pagou durante muito tempo. Esó agora, volvidos quase oitenta anos, a historiografia portuguesa de cariz científico começa, embora algo titubeante, a questionar as alegadas vantagens da nossa entrada no teatro europeu da guerra, revelando uma outra realidade: as fragilidades organizativas do C.E.P.; as crescentes dificuldades económicas e alimentares; uma opinião pública cada vez mais dividida quanto ao embarque para a Flandres; a indisponibilidade da Inglaterra, a partir de meados de 1917, para assegurar transporte naval ao roulement das tropas portuguesas, preterido em favor da intervenção dos americanos no conflito...

Podemos dizer que Augusto Casimiro cumpriu o seu papel, enquanto outros parceiros de barricada assumiram também o seu dever político-partidário.

(98) C. Ibidem, p. 339.

$\left({ }^{99}\right)$ Cf. Ibidem, p. 98. 
O Inspector da Polícia de Investigação Criminal de Coimbra, Eurico de Campos, preso na sequência da intentona democrática de 12 de Outubro de 1918, verteu no papel a sua total discordância em relação às investigações oficiais efectuadas e avançou com as suas próprias para concluir, mais por efeito de inferências vagas do que pela adução de provas concludentes, que a morte de Sidónio Pais só interessava aos monárquicos, pelo que "fôram os monárquicos, só os monárquicos, que armaram o braço que assassinou o Dr. Sidónio Pais" $\left({ }^{100}\right)$. E aponta um suspeito: o chefe da polícia do Porto, o controverso Sollari Allegro, que nas vésperas da viagem ao Norte de Sidónio Pais, sabendo que este o iria demitir, concebeu e mandou executar o crime!

Sem comparável esforço dedutivo (e especulativo...), Tomás da Fonseca, escritor republicano e anti-clerical ferrenho, chefe de gabinete do Ministro do Fomento no Governo Provisório da República, dr. António Luís Gomes $\left({ }^{10 t}\right)$, e implicado no complot de Mortágua associado ao 12 de Outubro de 1918, limitoumse a narrar em estilo diarístico a sua experiência de prisioneiro político nos cárceres do sidonismo, engrossando-a com impressōes sobre o carácter discricionário das autoridades sidonistas, as levas de prisioneiros inocentes, o "odio profundo pelos republicanos" evidenciado por "este Sidonio e a sua quadrilha" ou ainda com certos paralelismos históricos - para os seus "carcereiros" Sidónio era o retrato actual de "D. Miguel - o da forca e do cacete" $\left.{ }^{\prime 102}\right)$.

$\mathrm{E}$ a detracção, cada vez mais caudalosa, seguiu pelo seu leito na imprensa e fora dela...

Nas páginas de A Lucta, Brito Camacho, ex-amigo e ex-chefe político de Sidónio Pais, mostrou ter digerido mal o percurso a solo do pupilo, após o 8 de Dezembro de 1917 e que culminou na efémera República Nova. Vasou, por isso, alguns meses volvidos sobre o assassinato de Sidónio, um breve depoimento memorialístico sob o

$\left.{ }^{(1(x)}\right)$ Cf. Eurico de Campos, Quen sāo os assassinos do Dr. Sidónio Pais? (Estudo de investighação criminal), Coimbra, Livraria Editora F. França Amado, 1919, p. 31.

(101) Ver Tomás de Fonseca, Memórias dum chefe de gabinete. Prefácio de Lopes de Oliveira, Lisboa, Livros do Brasil, Limitada, 1949.

$\left.{ }^{102}\right)$ Cf. Idem, Memorias do carcere. (Subsidios para a historia contemporanea), Coimbra, França \& Armenio, 1919, p. 186. 
inócuo e singelo título de $\grave{A}$ Margem, misturando, num tom hábil e convincente, factos verídicos, omissões e distorsões, tudo isto para vincar bem a perene subalternidade do malogrado $4^{\circ}$ Presidente da República, que só chegou à ribalta política porque contou com um generoso e desinteressado "empurrão" camachista( ${ }^{(103) ! \ldots . .}$

Entretanto, nos escaparates das livrarias não tardou a aparecer um livro pequeno, de uma centena de páginas, escrito por um novelista temível, que se havia celebrizado com o popular romance Marquês da Bacalhoa, violenta diatribe contra os últimos Braganças, editada em Paris e entusiasticamente acolhida em Portugal. António de Albuquerque, de seu nome completo António de Albuquerque do Alardo de Amaral Cardoso e Barba de Meneses e Lencastre, nascido em Viseu, educado e instruído em França, anarquista e monarcómaco, boémio e snob, cosmopolita irrequieto (saltitara pela Europa, partira à descoberta de África e daí rumara ao Brasil), amigo de Claude Farrère, Anatole France, Paul Brulat entre outros escritores e intelectuais franceses, retornou à Pátria, instalou-se perto da capital e dispôs-se a singrar como escritor de sucesso junto dos seus compatriotas... No entanto, o seu biógrafo César dos Santos retratá-lo-á, em 1925, como O Despresado $\left({ }^{104}\right)$, num ensaio generoso de reabilitaçāo do amigo, falecido a 2 de Junho de 1923. No ano anterior tinha dado ao prelo Sidónio na Lenda. Estudo critico, com uma advertência curiosa: "Êste livro, escrito ha mais dum ano e que só agora lanço à publicidade, pelas imensas dificuldades com que travei luta e me venceram para a sua imediata publicação, visa apenas o estudo do homem público, ditador e revolucionário, que de direito pertence ao crítico e ao historiador. Se, muito ao de leve, me refiro a algumas pessoas da família de Sidónio Pais é apenas para demonstrar a sua degeneração e desiquilibrio atávicos; e isso mesmo o faço com constrangimento e por absoluta necessidade" $\left({ }^{105}\right)$. Deduz-se que the era necessário, imperioso mesmo, "autopsiar" a lenda de popularidade, do heroísmo e do assomo

(103) Ver Brito Camacho, "A Margem", A Lucta, 18 Set. 1919, p. 1.

(104) Ver César dos Santos, O Despresado. A Sua conversão. Carta a s. m. a rainha D. Amelia. O Regicidio e os politicos. Quem instigou o Marquez da Bacalhoa? Cartas e autografos sensacionais, Lisboa, Edição do Autor, 1925.

$\left({ }^{105}\right)$ Cf. António de Albuquerque, Sidónio na lenda. Estudo crítico por... Autor do "Marquez da Bacalhôa", Lisboa, Lumen Empresa Internacional Editora, 1922, p. [6]. 
messiânico tecida à volta de Sidónio Pais, homem de carne e osso, com taras e defeitos, poses e fantasias... E donde vinha tal necessidade? Do compromisso com o seu ideário político? Ou de uma razão inconfessável e mesquinha? Em 18 de Janeiro de 1918, António de Albuquerque escreveu num exemplar d'O Marquez da Bacalhôa $\left(5^{\mathrm{a}}\right.$ edição) a seguinte dedicatória: "Ao Dr. Sidonio Paes libertador de Portugal em 5 de Dezembro de 1917. Homenagem ao seu talento e raras qualidades de caracter" $\left.{ }^{\prime 106}\right)$. Justamente por essa ocasião tentara ser recebido pelo novo Chefe da Nação segundo o relato algo nebuloso, a meias cores, de César dos Santos. Insistira com o seu parente, alferes Bernardo de Albuquerque, membro da entoturage presidencial, sem êxito. Era-lhe negada a entrevista e por isso - só por isso?!...- jurava, nos salōes de Belém, vingança e proclamava irado: "- Pois bem. Querem a lucta? Para a lucta iremos. Já destronei um rei. Facil me é destruir um Presidente. Adeus, Bernardo" $\left.{ }^{107}\right)$. Podemos duvidar desta versão, mas a dedicatória, acima transcrita, contrasta imenso com o teor da sua demolidora charge anti-sidonista, concluída na Praia das Maçãs, aos 30 de Agôsto de 1919...

Impressionado com aquilo que designou por "fenómeno de loucura colectiva", ou seja, com a idolatria que a "sociedade portuguesa há tanto dementada, subserviente e incultamente crédula" consagrara a Sidónio Pais em vida e, sobretudo, diante da sua morte, António de Albuquerque não se conteve, puxou da pena para uma diatribe séria, em poses de dever da lucidez e do bom-senso( $\left.{ }^{108}\right)$. Desenvolveu-a sob um punhado impressivo de epígrafes - Sidónio na lenda, Sidónio na origem, Sidónio megalómano, Sidónio conspirador, Sidónio pacifista, Sidónio ditador, Sidónio diplomata, Sidónio orador, Sidónio morto, Tragi-comédia e Palavras de dois notáveis homens de letras a respeito de José Júlio da Costa, executor de Sidónio Pais. Esses dois homens de letras eram o anarquista Manuel Ribeiro que entrevistara o assassino para o jornal $A$ Batalha $\mathrm{e}$ o jornalista Bourbon e Menezes, chefe de gabinete de Bernardino Machado e declarado anti-sidonista. António de Albuquerque,

(106) Arquivo Pessoal de Sidónio Pais (A.P.S.P.) - António de Albuquerque, O Marquez da Bacalhôa. (Escandalos da côrte do rei Carlos), Lisboa, Livraria Brazileira de Monteiro \& $C^{\mathrm{a}}, 1912,5^{\mathrm{a}}$ ed.

${ }^{\left({ }^{107}\right)}$ Cf. César dos Santos, O Despresado, ob. cit., p. 16.

$\left.{ }^{108}\right)$ Cf. António de Albuquerque, Sidónio na lenda, ob. cit., pp. 8-9. 
apoiando-se em dados biográficos e em outras informaçōes (veiculadas pela imprensa ou oralmente) imprecisas, distorcidas e até bizarras, inaugurou, ao invés de Maria Feio, a desconstrução da lenda do Grande Morto, do Libertador, do Herói e Mártir, subentendida vulgarmente por mito, enquanto Fernando Garcia se entreteve a diagnosticá-lo...

Albuquerque conduziu, de facto, uma recolha de dados apressada e intencionalmente dirigida para as eventuais fraquezas da personagem, acolhendo o que pelos cafés e esquinas se contava do seu passado mais e menos recente ou o que ia transparecendo na imprensa. Basta, talvez, este impressivo exemplo: a passagem de Sidónio Pais pelos $1^{\circ}$ e $2^{\circ}$ Governos constitucionais da República e, sobretudo, a sua estada em Berlim como diplomata foram alvo de comentários pouco lisonjeiros, que Albuquerque reproduziu sem se esquecer de referir "que foi assíduo frequentador de bares dissolutos e casas suspeitas" $\left({ }^{1(x)}\right)$.

Revelaçōes de equiparável quilate fê-las, entretanto, João Chagas nas páginas do seu famoso Diário editado em 1930. Este talentoso publicista, que se distinguira nos tempos da aguerrida propaganda contra a Monarquia Constitucional agonizante, saltou para a ribalta política com o 5 de Outubro. Entrou na governação do país e foi encarregue da missão de representante diplomático em Paris, actividade que muito estimou e considerou talhada ao seu perfil, comportando-se, por isso, como uma espécie de "príncipe" dos diplomatas da República. Não obstante as suas críticas de intelectual refinado e cosmopolita, partilhadas, aliás, pelo seu grande amigo José Relvas, e endereçadas ao comportamento demagógico dos afonsistas e radicais do novo regime $\left({ }^{110}\right)$, manifestou-se, com o deflagrar da Grande Guerra, um intervencionista indefectível e nessa medida tratou a situação dezembrista/sidonista com total repulsa e sarcasmo. Notese, contudo, que quase ninguém, de Manuel de Arriaga a Bernardino Machado, foi poupado, para grande indignação de Bourbon e Meneses, susceptivel machadista $\left({ }^{111}\right)$.

(109) Cf. Ibiden, p. 14. Ver também pp. 57-58.

(110) Ver Correspondência literária e política com João Chagas, 3 vols., Lisboa, Editorial Noticias/Empresa Nacional de Publicidade, 1957-1958.

(111) Cf. Bourbon e Meneses, O Diario de loño Chagas. A Obra e o homem, Lisboa, J. Rodrigues \& C $\mathrm{C}^{\mathrm{a}}$ Editores, 1930, pp. 18-19 
Para João Chagas o major matemático, auto-proclamado Chefe da Nação em finais de 1917, foi obviamente um rematado cúmplice da corrente germanófila, monárquica, reaccionária e anti-patriótica e autor de uma sedição - a de Dezembro - "feita contra a guerra e para que não fossem mais soldados para a guerra" $\left.{ }^{112}\right)$. Espantou-se, porém, com o "delirante pranto" que se seguiu à sua morte $\left({ }^{113}\right)$ e ironizou perante o "subito enternecimento - são palavras suas - dos reaccionarios portugueses pela viuva e filhos de Sidonio Paes", dizendo que não sabia se dos filhos ele se ocupou, mas da mulher achava-se separado há muito tempo $\left({ }^{114}\right)$. A partir de 1919 as alusões directas a Sidónio Pais surgem asociadas à instabilidade vivida até à aventura restauracionista, enquanto para trás as poucas detectáveis prendemse com o seu discreto e isolado desempenho diplomático em Berlim. Nas impressões relativas a 12 de Outubro de 1915 desabafou com malévola ironia que do Teixeira Gomes, do Sidónio e do Eusébio Leão ("do especialista das vias urinárias que nos representa em Roma") nada sabia sobre os respectivos desempenhos político-diplomáticos, embora soubesse algumas coisas censuráveis: "O Oliveira [...] informou-se de que Eusébio Leão, que está separado da sua mulher, vive na cidade dos Cesares em companhia de uma concubina. O mesmo, segundo parece, succede ao Sidonio Paes, em Berlim. O Vasconcellos, em Madrid, dispensa a companhia da mulher e vive num hotel, como vive num hotel o Teixeira Gomes em Londres. Dos effeitos moraes de semelhante situação não se forma o menor juizo em Portugal"( $\left.{ }^{115}\right)$; em 24 do mesmo mês referiu que recebeu a visita em sua casa do jornalista Hermano Neves, o qual the referira como autêntico que "a amante do ministro de Portugal em Berlim, uma franceza, teria sido por este motivo expulsa

(112) Cf. Joāo Chagas, Diario de... 1918, Lisboa, Parceria Antonio Maria Pereira, 1930, p. 192.

(113) Cf́. João Chagas, Diario de... 1918, pp. 411 412.

(114) São estas as suas palavras: "Ja quando foi ministro no meu gabinete de 1911 vivia com outra. Quando me appareceu em Paris na sua ida para Berlim trazia esta, ou outra, que em todo o caso não era a sua legitima. Em Berlim teve uma amante com quem viveu e nunca para ali levou, ou apresentou a mulher. Finalmente, elevado á Presidencia da Republica, nunca a sua legitima mulher foi vista em Belem e quem era vista era uma amante, uma estrangeira, não sei se a mesma que o acompanhou a Berlim" (Cf. Ibidem, pp. 415-416).

$\left.{ }^{115}\right)$ Cf. João Chagas, Diario de... 1915, 1916 e 1917, ob. cit., p. 90. 
da Allemanha" $\left.{ }^{116}\right)$; em 23 de Fevereiro de 1916 não evitou uma alfinetada no diplomata Sidónio: "Desempenhou-se o Sidonio Paes d'esta missão? Deve ter sido curiosa a sua entrevista na chancellaria imperial. Este Sidonio Paes é um heroe. Se serve o paiz por dedicação no posto de Berlim, merece as coroas civicas" $\left({ }^{117}\right)$; e nos registos de $14 \mathrm{e}$ de 15 de Março de 1916 ocupou-se por inteiro do colega forçado pela guerra a retirar de Berlim e de passagem em Paris no regresso à Pátria vinha "magro como um cão" $\left.{ }^{118}\right)$.

O interesse deste testemunho tão "abrasivo" excede o seu conteúdo ao ajudar-nos a perceber o papel relevante da escrita diarística e memorialística no reforço e na eficácia dos discursos hagiográfico e de detracção, bem como a sua influência, muitas vezes acrítica, no oficio historiográfico. E mesmo a descrição alegadamente objectiva, factual e cronológica, sóbria e sucinta, ilustrada pelo volume Regímen Republicano da colecção Portugal Histórico, dirigida por A. Duarte de Almeida, no qual se sucedem, sem comprometedoras adjectivações, os principais eventos que vão do golpe de Dezembro à revolta de Monsanto( $\left.{ }^{119}\right)$, não está imune ao efeito modelador das narrativas quer de cunho monográfico e assumidamente parcial, quer de difusa evocação memorialística, ambas permeáveis à apologética ou à "demonização".

(11i) Cf. Ibidem, p. 105

(ii7) C. Ibidem, p. 203.

(118) E prosseguiu: "Dir-se-hia que vem de Coimbra, e é tão insignificante que é inconciliavel com a idéa que o vulgo costuma fazer de um diplomata.[...] Passou o dia e a noite nesta casa, onde jantou. Falou muito, não disse nada. [...] conversando-se um momento com elle, comprehende-se que semelhante ministro não podia ter a menor acção ou influencia.[...] A tarde, o Sauerwein do Matin, descobrindo-o em minha casa, veio entrevistá-lo. Apezar de lhe ter recommendado que falasse pouco, falou cem cessar, mal, deploravelmente mal. Difficilmente se concebe um diplomata tão ignorante de uma lingua tão necessaria! [...] Falou da politica portugueza, que só conhece pela Lucta, unico jornal, segundo disse, que o governo allemão lhe deixava chegar á Legação. Vê-se que o governo allemão sabia apreciar a politica do Brito Camacho. [...] Fallou então do Brito Camacho e, como todos os admiradores d'este genio nacional, declarou-o - um homem eminente. Este Camacho tem a admiração de todos os mediocres do tipo d'este Sidonio, nullos, mas diplomados, e com elles quiz fazer o seu partido, a que chama uma élite. É com effeito uma élite de mediocres". Cf. João Chagas, Diario de... 1915, 1916 e 1917, pp. 223-224.

(119) Cf. A. Duarte Almeida Almeida, Regimen repriblicano, ob. cit., pp. 142-182. 


\section{Imagens díspares no memorialismo e na ficção}

Umas quantas memórias, porventura menos lidas e citadas que as de Raul Brandão, as quais, como é sabido, incluem um capítulo dedicado a Sidónio no $3^{\circ}$ volume, Vale de Josafat $\left({ }^{120}\right)$, condensam um leque interessante de variações impressivas sobre a personagem e 0 seu enredo.

Carlos Eugénio Correia da Silva (Paço d'Arcos), na sua Vita Brevis, recorda o dia 27 de Maio de 1926 como "o último dia de sol da república velha, daquela que Sidónio Pais há oito anos julgava ter pisado aos pés e que afinal, assassinado o ditador, renascera como a hidra de Serna" $\left.{ }^{\prime 21}\right)$. O seu parente - o escritor Joaquim Paço d'Arcos, filho do comandante Henrique Correia da Silva, que comandou o pequeno cruzador Ibo, de 1915 a $1919\left({ }^{122}\right)$ - será bem mais contundente nas Memórias da Minha Vida e do Meu Tempo: “Dez dias depois as balas dum assassino prostravam na Estação do Rossio o Presidente Sidónio Pais. Julgara ele traçar a Portugal rumo que o seu idealismo fixara. E mais não deixou atrás de si do que confusão e miséria. [...]" $\left.{ }^{123}\right)$.

Mais mitigado, embora crítico, é o retrato esboçado por Urbano Rodrigues no seu estudo biográfico consagrado, em jeito de homenagem, a Teixeira Gomes, demitido logo após o 8 de Dezembro em conversa com Sidónio, registada nas páginas de um diário publicado postumamente por Castelo Branco Chaves $\left({ }^{124}\right)$. Urbano Rodrigues

${ }^{(120)}$ Cf́. Raul Brandão, Vale de Josafat. III volume de Memórias, Lisboa, Seara Nova, 1933, pp. 102-103.

(121) Cf. Carlos Eugénio Correia da Silva, Vita Brevis. Prefácio de Joaquim de Carvalho, Coimbra, Imprensa da Universidade, 1934, p. 40.

(122) Ver Henrique Corrêa da Silva (Paço d'Arcos), Memórias de guerra no mar, Coimbra, Imprensa da Universidade, 1931.

(123) Cf. Joaquim Paço D'Arcos, Memórias da minha vida e do men tempo, vol. 1, Lisboa, Guimarães \& C ${ }^{a}, 1973$, p. 149.

(124) Ver Manuel Teixeira-Gomes, Londres maravilhosa e outras páginas dispersas. Colectânea, notas e prefácio de Castelo Branco Chaves, Lisboa, Portugália Editora, s.d., pp. 132-141. O incidente é reproduzido, sem comentários e ao pé da letra do relato autógrafo do ex-ministro em Londres, por Norberto Lopes, $O$ Exilado de Bougie. Perfil de Teixeira Gomes. Com um estudo de Joño de Barros, Lisboa, Parceria António Maria Pereira, 1942, pp. 124-128. A incompatibilidade gerada entre o escritor algarvio e o major lente explicou-a José Carlos Vilhena Mesquita, num artigo publicado na revista História (Lisboa, 1988, pp. 20-33) e intitulado 
retrata Sidónio, após o seu regresso de Berlim, como uma figura muda, apagada e desinteressante, uma inteligência selectiva, opaca fora do domínio hermético das matemáticas $\left({ }^{125}\right)$.

Os comentários de Urbano Rodrigues não igualam, porém, o azedume, nem a condenação veemente assumida pelo general Norton de Matos num volume ainda inédito das suas Menórias e trabalhos da minha vida $\left({ }^{125}\right)$ - o $5^{\circ}$, concebido para justificar perante a História uma opção política e demonstrar a "má-fé" e a falta de patriotismo dos antiguerristas... - ou pelo seu correligionário e camarada de armas Sá Cardoso $\left({ }^{127}\right)$. Figuras proeminentes do 14 de Maio de 1915 e da "equipa de guerra" que o dezembrismo triunfante sujeitara ao opróbrio da prisão e do exilio.

Das prisões saíram, entretanto, sindicalistas e operários, vítimas dos protestos contra as restrições do período de guerra, queixosos da actuação governativa de afonsistas e almeidistas e esperançados num amanhã diferente. Não tardaram, porém, segundo o testemunho de Alexandre Vieira, a confrontarem-se com "O critério estreito, banal e vazio com que Sidónio Pais se manifestou então acerca dos assuntos sobre que a entrevista versara e a altivez do chefe do Governo - que contrastava singularmente com a quase meiguice do chefe da insurreição, quando com ele, acompanhado de Aurélio Quintanilha (que fora seu discípulo na Universidade de Coimbra), contactáramos no Parque Eduardo VII - deixou pessimamente impressionados os delegados da U.O.N., que a seguir faziam minucioso

"Teixeira Gomes o escritor burguês", com base nos atributos ditatoriais e germanófilos que Sidónio adquirira em Berlim!...

$\left.{ }^{125}\right)$ Cf. Urbano Rodrigues, A Vida romanesca de Teixeira Gomes. Notas para o estudo da sua personalidade e da sua obra, Lisboa, Editora Marítimo-Colonial, Lda, 1946, p. 139 e ver também 140.

(126) Ver Norton de Matos, Memórias e trabalhos da minha vida, 4 vols., Lisboa, Editora Marítimo-Colonial, 1944-1946. No A.P.N.M. existem dois volumes dactilografados $-5^{\circ}$ e $6^{\circ}$ - prontos para publicação, mas só há pouco foi possível retomar tal projecto com a esperança de que venha a ser concretizado o mais breve possível, juntamente com a reedição dos volumes anteriores e a elaboração de uma fotobiografia do general. Ver, também, Idem, "A Grande Guerra e as colónias portuguesas", in História da expansăo portuguesa no nutudo, vol. 3, Lisboa, Ática, 1940, p. 423 ss.

(127) Ver Sá Cardoso, Memórias duma época e apontamentos politicos, Lisboa, Edição do Autor, 1973, pp. 20-35. 
relato ao respectivo Conselho Central" $\left.{ }^{128}\right)$. A postura do Presidente e o agravamento da carestia de vida terão arrefecido os entusiasmos e imposto um inevitável afastamento convertido em ruptura na fracassada greve geral de 18 de Novembro de 1918. O Governo sidonista - conta Alexandre Vieira - aproveitou, então, para deportar, sem julgamento, trabalhadores rurais e prender os militantes sindicalistas mais conhecidos, entre os quais figuravam ferroviários do Sul e Sueste. $\mathrm{E}$ essas arbitrariedades tornaram-se mais graves após o atentado na estação do Rossio.

O grão-mestre Magalhães Lima foi uma das vítimas que sofreram a ira das autoridades e a de muitos populares em busca de mais presumíveis criminosos e conspiradores, como deixou escrito nos Episodios da Minha Vida, sob a epígrafe Dezembrismo. Aquela noite!( $\left.{ }^{129}\right)$.

Esses angustiosos e conturbados momentos viveu-os, também, Cunha Leal, mas da bancada dos apoiantes da governação sidonista, para onde fora parar pela amizade fraternal de Machado Santos: "mas ninguém - a começar por ele próprio - me poderia considerar seu sequaz, embora sem quebra da mais perfeita lealdade" $\left({ }^{130}\right)$. Reclamase, por isso, de uma inquebrantável independência, assim como de uma "estrita imparcialidade", que contrapōe à postura de seu amigo Rocha Martins, "honesto e laborioso jornalista e escritor", carecido, porém, segundo as suas próprias palavras, "de reais virtudes de historiador". $\mathrm{E}$ tanto no livro Eu, os Políticos e a Nação, como em As Minhas Memórias assinalou os excessos e os defeitos do Chefe ou "efémero Condutor da Grei", a quem atribuiu uma alegada capacidade mimética, patenteada durante a sua estada em Berlim: "[...] era, por assim dizer, uma crisálida germânica a querer perfurar o casulo democrático camachista, para dar lugar, mais tarde, por mero fenómeno de mimetismo, a uma borboleta de

$\left.{ }^{128}\right)$ Cf. Alexandre Vieira, Para a história do sindicalismo em Portugal. Notas preliminares de César de Oliveira, Lisboa, Seara Nova, 1974, pp. 121-122. Ver, também, Idem, En volta da minha profissão. Subsidios para a história do movinento operário no Portugal continental, Lisboa, Edição do Autor, 1950, pp. 102-120.

${ }^{(129)}$ Ver Sebastiāo de Magalhāes Lima, Episodios da minha vida. Menorias documentadas com fotografias e caricaturas, vol. 1, Lisboa, Livraria Universal de Armando J. Tavares, 1928, pp. 316-325,

${ }^{\left({ }^{130}\right)}$ Cf. Cunha Leal, Coisas dos Tempos Idos. As minhas memórins, vol. 2. $\mathrm{Na}$ periferia do tufño de 1 de Janeiro de 1917 a 28 de Maio de 1926, Lisboa, Edição do Autor, 1967, p. 72. 
asas irizadas em que, debalde, tentavam conciliar-se tintas ideológicas opostas" $\left({ }^{131}\right)$. Neste quadro não admira que a situação política subsequente tenha atingido a raia do trágico-cómico: "[...] a situação dezembrista estava convulsionada pela epilepsia da perseguição. O mêdo dos governantes fazia-lhes recear a própria sombra" $\left.{ }^{132}\right)$.

Uma situação, sem dúvida difícil e complexa, que Luís Cabral de Moncada, lente coimbrão, amigo e admirador de Salazar, caracterizou do ponto de vista político em poucas linhas: "O sidonismo foi um homem, Sidónio, e nada mais. Faltou-lhe um programa e uma fórmula teórica mágica, com raízes em qualquer sólida tradição, e sobretudo faltaram-Ihe colaboradores.[...] Sidónio Pais chegou, pelo menos, oito anos mais cedo do que devia ter chegado para a sua obra valer alguma coisa; antes disso, essa obra tinha em si mesma as razões da sua própria insubsistência" $\left.{ }^{133}\right)$.

Para quem participou fardado nessa obra, como foi o caso de Jorge Botelho Moniz, um dos "cadetes do Sidónio", o "Chefe" - termo empregue com entusiasmo e veneração - era essencialmente um militar e comandou um punhado de moços voluntaristas, patriotas exaltados, desdenhosos da República e dos políticos, que o seguiram fascinados $\left({ }^{134}\right)$. Sidónio Pais agigantara-se, pois, aos olhos de Botelho Moniz e dos companheiros, pela inteligência, pelo saber e pela sua visão, pelo seu projecto regenerador e nacional. Afinal, ele tinha uma projecto e era o seu animador. Era o homem superior indispensável para que tal projecto pudesse ser concretizado: "O mal da situação de Sidónio Pais não era, ao contrário do que se tem dito, estar consubstanciada num só Homem. As ditaduras, como todos os grandes movimentos reformadores, estão sempre na mão dum Homem. O mal residia na heterogeneidade dos elementos que a apoiavam. Na falta dum novo chefe de prestígio". Estas as razões do fracasso de uma obra pioneira que anteciparia o fascismo

(131) Cf. Cunha Leal, Coisas dos Tempos Idos. As minhas memórias, vol. 2, ob. cit., p. 68 .

(132) Cf. Idem, Eu, os políticos e a nação, Lisboa, Portugal-Brasil, s.d., p. 13.

(133) Cf. Luís Cabral de Moncada, Memórias. Ao longo de uma vida. (Pessoas, factos, ideias). 1888-1974, Lisboa, Editorial Verbo, 1992, p. 118.

${ }^{134}$ Cf. Jorge Botelho [Moniz], "Memórias dum ajudante de campo de Sidónio", A Situação, 21 Mar. 1927, p. 8. Ver Ibidem, 22 Mar. 1927, p. 1 e Ibidem, 24 Mar. 1927, pp. 1 e 8. Ver também Idem, O 18 de Abril. (Elenentos para a história duma revoluçāo vencida), Lisboa, Edição do Autor, 1925. 
italiano se não tivesse "morrido a vontade principal", imperando "a luta das vontades secundárias, das pequeninas e baixas vontades, das covardias, dos ódios, das ambições" ${ }^{\prime \prime}\left({ }^{335}\right) \ldots$

Um outro militar, que ao contrário do anterior se distinguirá pela oposição ao Estado Novo, João Sarmento Pimentel, nomeado em 1918 comandante do esquadrão da Guarda Republicana do Porto e impossibilitado pela pneumónica de exercer, durante alguns meses, essas funções, reassumidas na fase da Monarquia do Norte contra a qual combateu, acusou os monárquicos irredutíveis de terem traído a excessiva confiança de Sidónio Pais, figura evocada, aliás, com simpatia nas Memórias do Capitão $\left({ }^{136}\right)$. Segundo Sarmento Pimentel, em entrevista a Norberto Lopes, o fracasso da República deveu-se, em parte a Sidónio, por ter confiado demasiado na seriedade dos monárquicos, e aos próprios republicanos que se "recusaram a colaborar com ele. Os republicanos estavam, porventura, eivados de teorias utópicas, mas eram firmes nas suas decisões, diga-se em abono da verdade ${ }^{\prime \prime}(137)$. Convenceram-se que "o Sidónio tinha traído a Rapública, tinha traído a liberdade", no entanto "Ele era sinceramente republicano. A sua acção foi muito criticada. Depois da sua morte, porém, escreveu-se acerca dele muita coisa que não corresponde à verdade" $\left.{ }^{138}\right)$.

A referida sinceridade republicana de Sidónio Pais foi corroborada pelo coronel Gonçalo Pereira Pimenta de Castro, alegadamente monárquico $\left({ }^{139}\right)$, mas comprovadamente republicano unionista $\left({ }^{140}\right)$. Tinha ideias muito claras sobre qual deveria ser a atitude

$\left.{ }^{135}\right)$ Cf. "Os Defeitos da falta de unidade doutrinária", A Situação, 24 Mar. 1927, p. 8.

(136) Ver João Sarmento Pimentel, Memórias do capitão, Porto, Editorial Inova, 1974, pp. 189-204.

(137) Cf. Sarmento Pimentel ou uma gerą̧āo traída. (Diálogos de Norberto Lopes com o autor das "Memórias do Capitäo). Prefácio de Vitorino Nemésio, Lisboa, Editorial Aster, 1976, p. 113.

(138) Cf. Ibidem, p. 113.

${ }^{(139)}$ A sua atitude nas reuniões de altas patentes militares convocadas para una restauração pacífica da Monarquia foi de distanciamento em relação a esse desideratum, como lembrou o monárquico Gaspar de Abreu, Mentórias politicas. Prefaciadas pelo Dr. Alberto Pinheiro Torres, antigo deputado da Nação e ilustre jornalista, volume I, Braga, Edição do Autor, 1960, p. 272.

(14) Ver A.P.S.P. - Militar, Lente e Político, Geral, União Republicana. Assunto tratado adiante no capítulo 3 , "Dá vontade de morrer...". 
de atracção da República e evoca nas suas curiosas memórias episódios castrenses que deixam transparecer a preocupação do Presidente da República com a situação militar e o bom relacionamento que manteve com a oficialidade. O então comandante de Infantaria 16 resumiu as suas impressões pessoais num trecho muito favorável ao malogrado Presidente: "Era um Chefe de Estado bem preparado, com ilustraçāo, talento e até coração. Era um Chefe de Estado completo, como não é vulgar encontrar-se, porém, como dizia Alexandre Herculano, "nenhum país quer um bom governo!". O seu consulado foi tão benigno, que nem mesmo se defendeu. Ao seu coraçāo bondoso repugnavam vinganças ou perseguições. Como republicano, desde os bancos do liceu, era verdadeiramente liberal e tolerante, não desejando um Governo imposto pela violência. Queria a completa liberdade religiosa e política, mas também e acima de tudo o respeito pela lei. Só desta forma a República devia atrair e impor-se" $\left({ }^{141}\right)$.

Imagem de tolerância e de bondade retocada, também, pela memória do chefe da Polícia Pereira dos Santos, vertida em letra impressa por Manuel Nunes. O episódio contado seguiu-se à revolta frustrada de marinheiros no couraçado Vasco da Gama, em Janeiro de 1918, e tinha a ver com o destino a dar aos detidos. O Ministro do Interior, Machado Santos, convocara à sua presença o juiz dr. Joaquim Crisóstomo e o então agente policial Pereira dos Santos para lhes transmitir instruções sobre o processo dos 460 revoltosos, pelos quais sentia a camaradagem de marinheiro: "Coitados, são todos uns exaltados, mas amam sinceramente o seu país, embora nem sempre vejam bem as coisas, nem ao que se expõem! $\mathrm{E}$ após uma pausa: - Um, como juiz, outro, como agente, arranjam as coisas de forma que os presos sejam, pouco a pouco, restituídos à liberdade. É êsse o desejo do dr. Sidónio Pais!" $\left.{ }^{142}\right)$.

Ao esboço do político compreensivo e generoso juntou Vital Fontes, chefe do pessoal do Palácio de Belém, o perfil de um Sidónio Pais que "mal dormiu durante todo o tempo que esteve em Belém". Da

(141) Cf. Gonçalo Pereira Pimenta de Castro, As Minhas memórias, vol. 2, Lisboa, Expansāo Gráfica Livreira, Limitada, s.d., p. 56.

${ }^{\left({ }^{142}\right)}$ Cf. Manuel Nunes, As Memórins de um agente da policia. O chefe Pereira dos Santos contou-me a sua vida, Lisboa, Editora Marítimo-Colonial, Lda, 1945, p. 87. 
narrativa composta por Rogério Perez ressalta a entrega estóica ao trabalho, a índole esmoler, a comovente solidariedade para com as vítimas da pneumónica, a postura teatral que enlouquecia multidões... Fora de "palco", isto é, na "intimidade era calmo, e sereno nos momentos de perigo, ainda que tivesse assomos de cólera. Vivia modestamente" e cumpria um programa diário que começava pelas 8 $h$, quando se levantava, até à noite, nunca se deitando antes das 3 , por estar a trabalhar ou a receber visitas tardias. Fumava quatro maços de cigarros "baunilha" e, antes de se deitar, tomava um copo de leite para desintoxicar. Não constava que alguma senhora tivesse pernoitado no Palácio. Vital Fontes repete ainda a decantada analogia com D. Pedro V, a propósito das "fugas" de Sidónio Pais para o Palácio da Pena, em Sintra, mandado construir pelo pai daquele popular monarca. Alude à sua matriz profundamente republicana, evidenciada através do breve episódio dos retratos com dedicatória de D. Luís Filipe e de D. Manuel achados no dito palácio. E deixa clara a presença em seu redor de muitos oficiais jovens, de entre os quais o mais cuidadoso em matéria de expediente era o alferes miliciano Bernardo de Albuquerque, enquanto o capitão Cameira, "sempre muito irritado com todos, até com o sr. Botelho Moniz" (143) assumia o papel de "homem" de total confiança do Presidente.

Um fragmento memorialístico, conciso, mas impressivo por nos apresentar um Sidónio Pais agastado pelo cansaço e pela sucessão vertiginosa de problemas e de conspirações, confrangedoramente só e desiludido em Iuta desigual contra a adversidade, foi redigido como editorial do "seu" Diário de Notícias pelo jornalista, escritor e natural apoiante do Estado Novo, Augusto de Castro, com o título literário Unta noite com Sidónio $\left({ }^{144}\right)$.

Tomé José de Barros Queiroz, republicano histórico, unionista da primeira linha, durante anos envolvido na vida políticoadministrativa da Câmara Municipal de Lisboa, deputado, gestor e ministro da República, não deixou escritas as suas memórias, mas deixou

(143) Cf. Vital Pontes, Servidor de reis e de presidentes. Compilação de Rogerio Perez, Lisboa, Editora Marítimio-Colonial Lda, 1945, p. 106.

(1+) Ver Augusto de Castro, "Uma noite com Sidónio", in Idem, Homens e sombras. Retratos e ilustrações por Eduardo Malta, Lisboa, Empresa Nacional de Publicidade, [1958], pp. 121-126. 
"papéis" que o filho Vasco de Barros Queiroz compilou e ordenou numa narrativa filialmente apologética e alinhada por um democratismo primário em nome do qual a República Nova é reduzida ao epíteto de ditadura criminosa e irresponsável $\left({ }^{145}\right)$.

No lado oposto, quer por colaborar com o Sidonismo, quer por ser monárquico, esteve o polémico capitão António Adalberto Sollari Allegro, que também não terá escrito memórias, encarregando-se seu filho de redigir uma espécie de "biografia" política justificativa da acção controvertida de seu pai especialmente antes e durante a Monarquia do Norte $\left({ }^{146}\right)$.

Sígnificativa amostra $\left({ }^{147}\right)$ dos testemunhos memorialísticos em que é flagrante o contraste das representações da figura de Sidónio Pais e da sua Repuiblica Nova. Um contraste que se repete nos poucos textos literários (romances e contos) que conhecemos, enquanto nos manuais

(145) Ver Vasco de Barros Queiroz, Episódios da vida do político Thomé José de Barros Queiroz. Posfácio de João Medina, ob. cit.

(146) Ver José Luciano Sollari Allegro, Para a história da monarquia do norte, s.l., Edição do Autor, 1988.

(147) De um filão que parece inesgotável... O democrata, maçon, advogado ilustre e primeiro-ministro do $1^{\circ}$ Governo Provisório após o 25 de Abril, Adelino da Palma Carlos refere-se, nas conversas com Helena Sanches Osório, à morte de Sidónio a propósito da imputação do acto à Maçonaria: "A morte de Sidónio Pais também apareceu, de imediato, como um acto perpetrado por ordem da Maçonaria, por ter traído a própria Ordem e a República; sim, porque ele estava a trair a República, agindo como um monarca absoluto. Mas aquele José Júlio da Costa, que o matou, um sujeito um bocado transtornado da cabeça, não sei se era maçon" (Cf. Helena Sanches Osório, Um só rosto, uma só fé. Conversas com Adelino da Palma Carlos, Lisboa, Ediçōes Referendo Lda, 1988, pp. 177-178). Por seu turno, o decano dos jornalistas portugueses, Fernando Pessa, recordou uns fragmentos da sua vida de estudante em Coimbra que incluem dois pequenos incidentes relacionados com o Presidente da República Sidónio Pais (Ver J. P. S., "...E esta, hein?", Forum estudante, Lisboa, (5) Março 1992, pp. 54-56). E o poeta e escritor anti-salazarista José Gomes Ferreira escreveu as suas memórias políticas em êxtase e na sequência imediata do 25 de Abril, lembrando as suas "origens" e vivências republicano-afonsistas. Recorda, pelo meio, o "consulado histérico de Sidónio Pais" e em particular o enterro do "ditador" (Cf. Idem, Revoltç̧ão necessária, Lisboa, Diabril, 1975, p. 150). E mais adiante acrescenta, repetindo um "lugar-comum": "O consulado de Sidónio Pais foi sem dúvida a primeira experiência fascista europeia (o que nāo nos honra muito - comento eu neste momento) e muito anterior à de Primo de Rivera" (Cf. Ibidem, pp. 166-167). Por fim, em entrevista recente por ocasião do centenário do seu nascimento, Emídio Guerreiro, alistado 
do ensino primário oficial e liceal, aprovados durante a longa governação salazarista e marcelista, predomina e prevalece a mensagem do "precursor dos governos de autoridade" em ruptura com o "descrédito do parlamentarismo e a anarquia social" para "estabelecer a tranquilidade e o trabalho, a ordem e o progresso", antecipando assim a "reaç̧ão nacionalista da Revolução de 28 de Maio"(148). E no pós-25 de Abril os manuais do ensino primário de Meio Físico e Social são tão Iacónicos e redutores que Sidónio e o Sidonismo pura e simplesmente desaparecem, emergindo aqui e além ou como precursor do fascismo ou como algo política e socialmente justificado pelo respectivo contexto de crise e de guerra, a que a galante figura de Sidónio, "os desfiles militares, as brithantes recepções, suscitando toda a espécie de adesões" davam uma tonalidade especial, embora ao seu regime faltassem "os necessarios quadros para executar o seu programa, pois os republicanos em breve o abandonariam" ${ }^{\prime \prime}$. E daí a sua queda rápida e inexorável $\left({ }^{149}\right) \ldots$

voluntariamente aos dezassete anos e participante na revolta de 12 de Outubro de 1918 contra o Governo de Sidónio Pais, reviu, entretanto, o seu anti-sidonismo e explicou a sua posição actual nestes termos: "O Sidónio fez a sua revolução em Dezembro contra o Partido Democrático, que era o partido do dr. Afonso Costa. O Sidónio era republicano, nosso embaixador na Alemanha, e conhecia bem a organização militar alemã. Nessa altura, em 1917, como eles tinham tido êxitos militares enormes, estava convencido que a Alemanha ganharia a guerra e que Portugal ficaria numa situação muito trágica com a derrota dos Aliados. Hoje estou convencido que Sidónio Pais, que era um republicano " maçon", fez a revolução para evitar o maior mal no caso da derrota aliada..." (Cf. [O Cavaleiro da liberdade], "Fui sempre um romântico", Revista. Expresso, Lisboa, 4 Set. 1999, p. 38).

${ }^{\left({ }^{4}\right)}$ Ver, por exemplo, Arsénio Torres de Mascarenhas, Ensino Primário Oficial. História de Portugal. Edição ilustrada remodelada e ampliada de harmonia con os principios de orientaçäo educativa do Estado Novo por Joño Afonso de Miranda, advogado, oficial do Exército e antigo professor do Colégio Militar. Aprovada oficialnente, Lisboa, Liviaria Pacheco, 1937, pp. 88-93; Marques de Queirós, Epitone de História de Portugal (Segundo os novos programas) $10^{\mathrm{a}}$ edição, Porto, s.n., s.d., pp.76-77; António G. Mattoso, Compêndio de história de Portugal. Aprovado oficialmente como texto único para o 6" ano dos Licells, Lisboa, Livraria Sá da Costa Editora, s.d., pp. 771-775; e José Carlos Amado, História de Portugal, segundo volume, Lisboa, Verbo Juvenil, 1966, p. 65.

${ }^{(49)}$ Cf. Primeiras perguntas sobre história de Portugal. A Prineira e a segunda repilblica, 11. Sugestāo de J. Veríssimo Serrão. Pesquisas e textos de J. Aires Magalhāes. Ilustraçōes de Lino António Tudela, Lisboa, Edição Formar para Círculo de Leitores, s.d., pp. 30-31. 
Na literatura e descontado, por estar já resumido atrás, o romance de Pierre Benoit, que enfatiza em Sidónio Pais a ressurgência messiânico-sebastianista, o leque de imagens não é variado, mas muito esclarecedor quanto ao estereotipismo reducionista que the vem servindo de legendagem.

No romance Moleque Ricardo de José Lins do Rego $\left({ }^{150}\right)$ um personagem - o "Seu Alexandre", emigrante português, trabalhador, avarento e dono de uma Padaria - evoca Sidónio Pais como o "endireita" do país, exclamando: "Que homem enérgico, que administrador de mão cheia" $\left.{ }^{151}\right)$. Exclamaçāo que se repete na boca do tenente, "cadete do ditador", personagem de O Milagre segundo Salonté de José Rodrigues Miguéis $\left({ }^{(152)}\right.$ ou na boca do Padrasto da Missa in Albis de Maria Velho da Costa: "'Ah o Sidonio, que homem', diz o padrasto 'nunca mais o país levantou cabeça como nesses dias, lembraste, jóia?"' (153). Nos Trabalhos e Paixóes de Benito Prada de Fernando Assis Pacheco aparece a "Figura enigmática" do "dr Sidónio Bernardino da Silva Pais, nascido em Coimbra - assim rezam as Enciclopédias e os Dicionários Ilustrados acessíveis a escritores... - mas com antecedentes no Minho" $\left.{ }^{15-1}\right)$, cuja morte o Jorge Ourives previa às mãos de um pistoleiro "acirrado pelos inimigos", que eram "Todos os outros, sem esquecer os monárquicos e os católicos, que são de uma só ninhada e ele traz na palma da mão, esse parvo" (155). Opinião partilhada pelo "folhetinista" de Vila Velha: "Passadas umas semanas, foi a vez de cair, fulminado por um atentado, o major-presidente, de seu nome Sidónio Pais. Morto a tempo, quando a estrela redentora começava a empalidecer, teve funerais nacionais que se transformaram no adeus a outro encoberto. Segundo as testemunhas vila-velhenses que

(15i) Ver José Lins do Rego, O Moleque Ricardo, Lisboa, Edição Livros do Brasil, s.d. [1" ed. 1935].

(151) CE. Ibidem, p. 180.

${ }^{\left({ }^{152}\right)}$ Ver José Rodrigues Miguéis, O Milagre segundo Salomé. (Lenda contemporn̂nea). Romance, vol. 1, Lisboa, Estudios Cor, 1974, p. 240.

(153) Cf. Maria Velho da Costa, Missa in albis, Lisboa, Círculo de Leitores, 1989, pp. 111-112.

${ }^{\left({ }^{54}\right)}$ Cf. Fernando Assis Pacheco, Trabalhos e paixōes de Benito Prada. Galego da Provincia de Ontrense, que veio a Portugal ganhar a vida, Porto, Ediçōes Asa, 1993 , p. 112.

(155) Cf. Ibideni, pp. 112-113. 
expressamente se deslocaram a Lisboa, a urna balouçava num mar de gente salpicado de cenas de histeria e tiroteio esparso. $O$ defunto deixava os monárquicos ao assalto do poder" $\left.{ }^{156}\right)$. $O$ defunto revelarase, afinal, o coveiro da República, segundo a confissão de Carlos Rebello de Gualdym, arrependido sidonista e autor do ficcionado diário, com início em Dezembro de 1917 e fim a 14 de Dezembro de 1918 (capítulo XII - De cócoras!), que Artur Villares "descobriu" e "editou" $\left.{ }^{157}\right)$. Um ano de morte e ódio, de prisões e de "lacraus", alcunha dos civis armados, pretensamente ao serviço do Sidonismo, que perseguiram e mataram democráticos, espalharam-se pela cidade e semearam o terror. O alter-ego de Garcia Barreto, protagonista e narrador, encerrou um ano de agitada vivência política com esta tirada: "Horas depois soube que o Presidente expirava após ter chegado ao Hospital de $S$. José. 'Morro bem! Salvem a pátria!', terá dito quando sentiu a vida abandoná-lo. Últimas palavras de que tomei conhecimento através dos jornais do dia seguinte. Senti um alívio difícil de explicar. Tinha sido outro a concluir com eficácia e alguma loucura o gesto que me fora indicado por um rei de espadas. Antes assim" (158).

\section{Novos rumos historiográficos}

Num derradeiro impulso panorâmico, resta-nos completar toda esta dicotómica produção representacional - hagiografia e detracção -, longamente desmontada, com o que se conhece do renovado exercício científico e crítico da História.

Já focámos atrás os principais paradigmas norteadores do trabalho historiográfico sobre a ascensão e queda da $1^{\text {N }}$ República portuguesa, à luz dos quais foram inevitavelmente desenvolvidas as abordagens monográficas (ou específicas do ponto de vista temático) até agora publicadas àcerca de Sidónio e do Sidonismo. É, pois, dentro desse enquadramento paradigmático que se impōe a apreciação possivel das referidas abordagens.

(156) Cf. Álvaro Guerra, Café Repuiblica. Folhtetim do mundo vivido em Vila Velha (1914-1945), Lisboa, O Jornal, 1982, p. 34.

(157) Ver Artur Villares, A Leva da Morte, Lisboa, Livros Horizonte, 1988.

(15s) Cf. Garcia Barreto, A Cidade dos Lacraus. Romance, Lisboa, Editorial Escritor, 1994, pp. 249-250. 
Na Iinha marcada pela obra colectiva de Luís de Montalvor, claramente apostada na defesa do ideal e da obra republicanas, destacam-se Carlos Ferrão e Raul Rego - "fontes" inspiradoras de uma gama incontrolável de estudos ${ }^{(159)}$. Raul Rego dissertou sobre o Mito de Sidónio Pais numa comunicação apresentada ao Seminário LusoGalaico, que decorreu em Caminha, a 21 de Outubro de 1984, texto incluído com ligeiras alteraçōes na sua História da República. O autor pretendeu, tal como já fizera António de Albuquerque, desmontar a auréola de messianismo formada em volta de Sidónio, sem recorrer, nem cruzar documentação arquivística ou inédita de diversas procedências, o que é, aliás, quase um denominador comum dos estudos até agora elaborados sobre o tema. A lenda de Sidónio atingira, pois, o paroxismo com a sua morte, ofuscando, segundo Raul Rego, a verdadeira face das suas intençōes. Sidónio era um monárquico que na primeira ocasião trairia definitivamente o regime instaurado em 5 de Outubro de 1910: "O seu regime foi sem dúvida um ensaio do fascismo italiano e ele é bem uma figura do Duce, do Franco" $\left({ }^{160}\right)$.

Numa perspectiva similar, David Ferreira escreveu a sua História Politica da Primeira Repuiblica Portuguesa e um desenvolvido verbete sobre Sidónio Pais para o Dicionário de História de Portugal de Joel Serrão. Servindo-se dos dados disponíveis, a maioria dos quais de fiabilidade duvidosa, descreveu com sobriedade a carreira do cidadão e do político. Nesta faceta destacou, obviamente, antes da fase presidencial e com base na produção legislativa mais significativa, a

(159) A título de exemplo ver a caracterizaçāo negativa do período sidonista por Paulo Madeira Rodrigues, Tesouros da caricatura portugutesa, 1856-1928. A Política portuguesa através da sátira ilustrada, Lisboa, Círculo de Leitores, 1979, pp. 115-121.

${ }^{\left({ }^{160}\right)}$ Cf. Raul Rego, História da República. Vol. 4 - Do Sidonismo ao 28 de Maio, ob. cit., p. 60. Ver também um curioso artigo publicado no Diário de Notícias, que marca bem a posição político-ideológica deste autor face ao Sidonismo: Idem, "Vamos livrar-nos do sidonismo? OSidonismo é uma mistura de autoritarismo e populismo que vive, acima de tudo, da propaganda exclusiva, calando com leis censórias os seus adversários", Diário de Notícias, 1981. Interrogamo-nos ainda se o mesmo autor não terá, pelo menos, inspirado uma notícia anónima saída no mesmo periódico, em 1982, a propósito de umas polémicas afirmaçōes do orador da cerimónia oficial e evocativa dos 145 anos da Academia Militar (cf. "Evocação de Sidónio", Diário de Notícias, 14 Jan. 1982). 
função de deputado nas Constituintes, a de Ministro do Fomento e das Finanças entre 1911 e 1912 e a missão diplomática em Berlim, sobre a qual não resistiu à argumentação guerrista da alegada germanofilia de Sidónio Pais, afirmando: "Parece fora de dúvidas que, durante a sua permanência em Berlim, Sidónio Pais, deslumbrado pela grandeza militar e pelo aparato das paradas e exibiçōes marciais, terá ficado muito impressionado também pela cega obediência e pela disciplinada passividade de quase todo o povo alemão perante os poderes do Estado. Deve ter derivado daí a sua paixão pelo 'presidencialismo', que nada no seu passado autorizava a vaticinar-lhe. A sua simpatia pela Alemanha e a sua conviç̧ão de que esta seria a vencedora da guerra são, aliás, transparentes nas próprias comunicações oficiais que, acerca do conflito em marcha, envia para o nosso Ministério dos Negócios Estrangeiros" $\left({ }^{161}\right)$.

A historiografia de recorte nacionalista trabalhou uma tese paradoxalmente próxima da defendida por Carlos Ferrão $\left({ }^{162}\right)$ ou por Raul Rego - Sidónio foi o "Libertador". Libertou o país da desordem, da corrupção dos políticos, da barafunda republicana; foi um ditador nacionalista, que se deixou envolver na teia dos monárquicos e dos integralistas. Ferrão ousará mesmo dizer que o Integralismo Lusitano se mascarou de presidencialismo. Sem tocar tais extremos, não andou longe a opinião reflectida na Histoire de la République Portugaise de Artur Ribeiro Lopes $\left({ }^{163}\right)$, no Revolutionary Portugal (1910-1936) da autoria de V. de Bragança-Cunha $\left({ }^{164}\right)$, no $2^{\circ}$ volume das Páginas de Sangue de Sousa

(161) Cf. David Ferreira, "Pais, Sidónio Bernardino Cardoso da Silva", in Joel Serrāo (dir.), Dicionário de História de Portıgnl, vol. 3, Porto, Iniciativas Editoriais/Livraria Figueirinhas, p. 281.

(162) Este publicista, infatigável artífice da reabilitação da $1^{a}$ República face à História, não dedicot nenhum desenvolvido estudo monográfico ao Sidonismo, limitando-se a escrever um ou outro artigo de jornal. Ver sobre isto Armando Barreiros Malheiro da Silva, Sidónio e sidonismo. História e mito, vol. 1, dissert., p. 102.

(163) Ver Artur Ribeiro Lopes, Histoire de la république portugaise, Paris, Les Oeuvres Françaises, 1939, pp. 195-200. Merece atenção na narrativa deste autor um pormenor curioso: ao apresentar o assassino do Presidente da República Nova, José Júlio da Costa, refere que ele era "primo do assassino do rei D. Carlos", parentesco raramente evocado...

(164) Ver V. de Bragança-Cunha, Revolutionary Portıgal (1910-1936), London, James Clarke \& Co, 1939, pp. 183-185. 
Costa $\left({ }^{165}\right)$ e na obra premiada de Jesus Pabón, escrita com desenvoltura e leveza num estilo adequado à divulgação histórica, assentando, sobretudo, nas fontes diarísticas e memorialísticas focadas atrás. Com base em todo esse material primário, o historiador espanhol procurou chegar onde queria, ou seja, à explicação do drama de Sidónio País, à tragédia do sidonismo( $\left.{ }^{166}\right)$. Um ditador e uma ditadura muito imperfeitas, imersas num equívoco insuperável: o presidencialismo deveria ser a modificação necessária e suficiente para se manter inalterável o republicanismo demo-liberal. Mas não foi, não podia ser... A sonhada unidade dos portugueses em torno de um projecto nacional, pelo qual Sidónio Pais lutou sozinho e traído pelos seus próprios preconceitos liberais, essa unidade, tão perigosamente estilhaçada desde 5 de Outubro pela fratricida e interminável luta entre "talassas e formigas", só um outro homem, em outras circunstâncias históricas, conseguirá conquistá-la - Salazar.

No meio destas leituras demasiado pautadas pelo conflito político-ideológico que opôs demoliberalismo e socialismo a autoritarismo nacionalista e fascismo, foram rompendo, com dificuldade, outros rumos mais matizados e equilibrados com o fito de rever a figura histórica e a sua obra. Achegas raras, esparsas e sumárias, que ficaram muito aquém da necessária, mas espinhosa e invulgar tarefa biográfica, assim como da análise crítica e profunda do Sidonismo no cerne da evolução do republicanismo português. Podemos até acrescentar que, por exemplo, o artigo anónimo "Um Perfil e uma Obra" publicado na Vida Mundial de 8 de Dezembro de 1967, a coluna "Sabe quem foi? Sidónio Pais" do Diário Popular de 28 de Março desse mesmo ano ou ainda a resenha biográfica, sem título, incluída no número especial de $O$ Caminhense dedicado às comemoraçōes do centenário do nascimento de Sidónio Pais, 1872-1972, são excepções na medida em que não exibem os muitos e graves erros a nível cronológico e factual que habitualmente adornam o curriculum vitae de Sidónio.

(165) Ver Sousa Costa, Páginas de sangue. Buiças, Costas \& Companhia, Lisboa, Livraria Editora Guimaräes \& Ca, s.d., pp. 225-238. p. 316 .

${ }^{\left({ }^{6} 6\right)}$ Cf. Jesus Pabón, A Revoluçño portuguesa, Lisboa, Editorial Aster, 1961, 
Com a renovação da historiografia portuguesa, no pós II Guerra Mundial, sob o efeito das novas correntes sopradas de fora, nomeadamente a Nova História francesa e o marxismo, a problematização aberta e séria sobre o processo histórico contemporâneo, arredado, como se sabe, do ensino oficial e universitário por imperativos de censura política e ideológica, fará o seu inexorável curso graças ao esforço dos que, cá dentro ou no exílio e antes do 25 de Abril de 1974, se aventuraram a estudar os "demasiado próximos" e "demasiado incómodos" sécs. XIX e XX.

No pouco que se publicou até essa data acerca da $1^{a}$ República e das suas crises os Estudos sobre Sidónio Pais de Vasco Pulido Valente dois artigos publicados, em Maio-Junho e em Julho-Agosto de 1968, na revista de pensamento e acção O Tempo e o Modo, o primeiro com o subtítulo de "Comércio e Distribuição em 1918" e o segundo "Agricultura e Proletariado Agrícola: Indústria e Sindicatos; Comércio Externo" $\left({ }^{167}\right)$ constituíram uma estimulante novidade do ponto de vista metodológico e hermenêutico, embora as vertentes focadas e circunscritas ao difícil ano de 1918 já tivessem merecido a atenção de Teófilo Duarte mas com intuitos bem diversos. Inserida num projecto mais amplo e de maior fôlego $\left({ }^{168}\right)$, essa abordagem incipiente permanece como uma prospecção modelar da situação económica e social vivida em Portugal em pleno impacto das consequências do conflito bélico internacional, bem como da solução ou soluções políticas postas em prática pelos governos de Sidónio Pais.

Um dos tópicos aflorados - a questão social e a reacção do movimento sindical, nas cidades e nos campos, à asfixiante carestia da vida - e o inevitável problema jurídico-político foram, aliás, objecto

(167) Ver Vasco Pulido Valente, "Estudos sobre Sidónio Pais", in Idem, Estudos sobre a crise nacional, Lisboa, Imprensa Nacional-Casa da Moeda, 1980, pp. 243318.

$\left.{ }^{16{ }^{16}}\right)$ No A.P.S.P., SubSistema Capitāo Sidónio Bessa Pais há uma carta do autor, acrescida de um inquérito a preencher pelo filho e familia do Presidente da República Nova, na qual é expressamente formulado o projecto de uma "biografia" que integrasse e aprofundasse a análise parcial saída a lume em $O$ Tempo e o Modo. Através de tal diligência percebe-se a necessidade de acesso a fontes arquivísticas e a informações inéditas, indispensáveis para um balanço crítico do estado do tema e para eventuais saltos qualitativos. Infelizmente, não houve sequência e o projecto foi interrompido. 
de diversas e desiguais contribuições, à luz principalmente da perspectiva marxista, por José Pedro Gonçalves e o seu folheto antológico O Presidencialismo português( $\left({ }^{169}\right)$, por José Pacheco Pereira, por António José Telo e, uns anos mais tarde, por Victor de Sá com uma brevíssima Reflexão (Cronológica) sobre o Sidonismo $\left({ }^{(70}\right)$, em que glosa a coincidência histórica do aparecimento do fenómeno políticosocial dezembrista um mês após a vitória da revolução soviética na Rússia, sublinhando as diferenças entre os dois e que em Lisboa triunfara uma contra-revolução de tipo demagógico e ditatorial, mais tarde em voga noutros países por efeito da reaç̧ão ao comunismo.

José Pacheco Pereira começou por inserir a situação difícil vivida pelo movimento operário na fase aguda da "economia de guerra" no quadro histórico das condiçốes especiais e precárias do capitalismo português, incidindo depois sobre a atitude do Poder face à erupção reivindicativa que uma agudíssima carestia de vida tornou perigosa para a sobrevivência do sistema político e que culminará na greve geral de Novembro de $1918\left({ }^{171}\right)$. Da análise, muito anotada e apoiada em bibliografia específica e na imprensa operária e burguesa, ressalta a inoportunidade do momento escolhido - entre a assinatura do armistício e o alastramento epidémico da pneumónica - para a greve geral, o que terá até influído no seu fracasso, e a violenta repressão policial e militar lançada pelo governo sidonista sobre o movimento grevista. Pacheco Pereira observa, a dado passo, que o Sidonismo reprimiu as greves com a mesma violência que o odiado governo de Afonso Costa antes tinha usado.

Aspecto interessante que o desenvolvido estudo de António José Telo absorveu e ampliou consideravelmente, porque se propôs demonstrar que o Sidonismo fez parte de uma estratégia claramente assumida e accionada pelas classes possidentes portuguesas, apoiada pelo Partido Socialista, que procurava, face à alteração táctica da U.O.N., ser reconhecido como o legítimo representante dos

(169) Ver [José Pedro Gonçalves], O Presidencialisno portughuês. Textos de Sidónio Pais, Oliveira Salazar, Marcelo Caetano e tma introdução. Seleç̧ão e notas de..., Lisboa, Iniciativas Editoriais, 1971.

$\left({ }^{170}\right)$ Ver Victor de Sá, "Reflexão (cronológica) sobre o sidonismo", Revista da Faculdade de Letras, Porto, $2^{a}$ série, 6, 1989, pp. 355-361.

(171) Cf. José Pacheco Pereira, As Lutas operárias contra a carestia de vida em Portugal. A Greve geral de Novembro de 1918, Porto, Portucalense Editora, 1971. 
trabalhadores. Embora tivesse durado apenas um ano deixou como herança um sistema institucional (bases do Estado autoritário e repressivo...) que haveria de permitir nas condiçōes portuguesas e num clima de certa "histeria bolchevista", "a união das principais classes possuidoras, e não será por acaso que a 'Constituição de 1918' será repetida praticamente ponto por ponto na de $1933^{\prime \prime}\left({ }^{172}\right)$. À parte os dados estatísticos e a factologia sindical, a interpretação construída pelo autor assentou, como não podia deixar de ser, na massa de informação histórica disponível sobre o tema, a qual, como temos frisado, está minada pela distorsão hagiográfica ou pelo espírito de detraç̧ão. Resvalou também para o reducionismo típico da matriz marxista e daí afirmaçōes como esta: "O modelo Sidonista baseava-se [...] em favorecer os latifundiários e o mundo rural em geral sem prejudicar a burguesia" $\left({ }^{173}\right)$; ou "Para Sidónio Pais a principal preocupação era a de manter a união das classes possuidoras que the tinham dado o apoio" $\left({ }^{174}\right)$; ou ainda esta tirada mais longa, mas mais elucidativa: "A história do Sidonismo, no que diz respeito às classes possuidoras, vai assim ser marcada por dois factores: por um lado pelas tentativas do poder para encontrar uma fórmula político-económica que permita a continuação da sua união e a conciliação de interesses divergentes ou antagónicos; e, por outro, pelo lento, mas progressivo e seguro, abandono de um sector após outro da burguesia, que se sentia prejudicada pelo tratamento preferencial que era dado aos latifundiários e camponeses, deixando o Sidonismo cada vez mais entregue ao apoio dos campos, e do seu principal representante político: os monárquicos" $\left.{ }^{\prime 175}\right)$.

O citado José Pacheco Pereira, na recensão ao trabalho de António José Telo, dividida em dois artigos publicados no $2^{\circ}$ Cademo Cultura do Diário de Notícias, não pôs obviamente em causa o paradigma historiográfico subjacente, nem a interpretação global do processo político da $1^{\text {a }}$ República, Sidonismo incluído $\left({ }^{176}\right)$. Embora orientasse as suas

$\left.{ }^{172}\right)$ Cf. António José Telo, O Sidonismo e o movimento operário portugutês: lita de classes em Portugal 1917-1919, Lisboa, Ulmeiro, 1977, p. 249.

(173) Cf. Ibidem, p. 161.

(174) Cf. Ibidem, p. 148.

(175) Cf. Ibidem, p. 142.

(176) Para Pacheco Pereira não havia dúvidas: "O sidonismo não só foi o retrato, 'avant la lettre', do Estado Novo que estava para vir, como condensou 
críticas sobretudo para a parte que considerou menos conseguida do livro, ou seja, o aprofundamento e a leitura das relações e das (des)ilusões do operariado na República, reclamou o confronto com outras análises complementares que pudessem alargar a compreensão da problemática social: "O sidonismo é apresentado como 'a primeira experiência de uma ditadura moderna' (p. 5) que 'marca o verdadeiro começo do século $X X$ em Portugal' (p. 9) afirmação que merece ser contraposta e completada com a análise do carácter tardio do jacobinismo português, feita por V.P. $V$., para medirmos com que lastro e vapor os portugueses entraram no século $X X^{\prime \prime}(177)$.

Este tipo de reflexões, obviamente estimuladas pela irresistível tentação de se explicar o passado pelo presente (a História escreve-se da frente para trás, é certo, porém quanto menos escrita for nessa direç̧ão mais História será...), inscreve-se num debate sobre a crise do Estado liberal e a génese do autoritarismo no período de entre guerras, no qual interveio uma nova geração de historiadores e sociólogos, regressados alguns deles com a Revolução de Abril.

Manuel Villaverde Cabral participou com alguns estudos estimulantes nesse debate, vindo a publicar na revista Análise Social um ensaio de interpretação do Sidonismo no contexto da Grande Guerra, considerado um momento importante no processo de fascização do sistema político português. E tendo em vista este tópico central o autor concluiu que se a ditadura de Sidónio anuncia as futuras ditaduras europeias do período de entre guerras, ela aproxima-se mais das ditaduras não institucionalizadas de um Horthy ou de um Pilsudski do que das de Mussolini e, mais tarde, de Salazar, por não conseguir ultrapassar o estádio "da ditadura sobre os mecanismos políticos de representação e arbitragem do liberalismo tradícional" e não conseguir, por isso, "esses mecanismos pelos mecanismos da representação vertical corporativa,

uma velha aspiração cesarista e bonapartista de parte da 'elite' intelectual burguesa, reaccionária ou progressista, que desde Herculano, Oliveira Martins e Ramalho contrapunha à 'porca da política' partidária a acção de um déspota esclarecido, capaz de dar ao País o sentido histórico que o parlamentarismo manifestamente não conseguia imprimir-lhe" (Cf. José Pacheco Pereira, "O Sidonismo e o movimento operário", Diário de Notícias, $2^{\circ}$ Caderno Cultum, 23 Nov. 1978, p. 19).

(177) C. Ibidem, p. 19. 
ou então nunca o logrando levar a cabo ${ }^{\prime \prime}\left({ }^{178}\right)$. Apesar de autoritária e repressiva a experiência sidonista não passou, portanto, de uma ditadura incompleta, presa ainda a algumas amarras do liberalismo tradicional...

É interessante este reparo de Villaverde Cabral, antecipado já pelos autores nacionalistas e fascizantes mais prosélitos - aludimos concretamente a João de Castro Osório -, que atribuíram, sem hesitação, aos preconceitos liberais de Sidónio Pais uma quota parte do fracasso da sua República Nova. No entanto, tais preconceitos não eram suficientes para estorvar a sugestiva analogia teórica entre Sidonismo e Estado Novo ou entre aquele e as ditaduras autoritárias de Primo de Rivera, Horthy ou Pilsudski ocorridas nos anos vinte e trinta. E não surpreende que em torno dela surgissem recentemente algumas "variações" pontuais $\left({ }^{179}\right)$, sendo, porém, de destacar as de Filipe Ribeiro de Menezes e de António José Telo.

Num artigo intitulado "Sidonio Pais, the Portuguese 'New Republic' and the Chalenge to Liberalism in Southern Europe" $\left.{ }^{180}\right)$ Filipe Ribeiro de Menezes após uma sucinta análise da "experiência sidonista" e, designadamente, do seu traço corporativo, importado não dos integralistas, como se tem repetido à saciedade, mas sobretudo da "herança intelectual" legada por Oliveira Martins, entende não ter havido por parte dos apoiantes de Sidónio Pais o desejo de mudança radical da sociedade e da criação de um "Homem Novo", ao contrário dos objectivos fulcrais do movimento fascista, e, nesta medida, parecelhe mais óbvia e frutífera a comparação com Salazar $\left({ }^{181}\right)$.

$\left.{ }^{178}\right)$ CF. Manuel Villaverde Cabral, "A Grande Guerra e o sidonismo (esboço interpretativo)", Análise Social, Lisboa, 15(58), 1979, p. 385.

${ }^{(79)}$ É o caso, entre outros, dos artigos de jornal de Jorge Pinto, "1-As Origens do fascismo em Portugal. A Ditadura de Sidónio Pais", Voz Popular, Lisboa, 5 Set. 1978, p. 23; de António da Costa Pinto, "O Fim da 'República Nova"”. Com a morte de Sidónio Pais rúa também a experiência de congregação das forças conservadoras; o partido único só com o projecto político de Salazar encontraria terreno fértil. Diário de Notícias, 6 Jan. 1981; e de José Subtil, "Sidónio Pais. A Ideia e a palavra", Diârio de Noticias, Suplentento "História", 11 Ágo. 1983, p. 7.

$\left({ }^{(12)}\right)$ Filipe Ribeiro de Menezes, "Sidonio Pais, the Portuguese 'New Republic' and the Chalenge to Liberalism in Southern Europe", European History Quaterly, London, 28, 1, Jan. 1998, pp. 109-130.

(181) Ver Ibidem, p. 125 ss. 
Reformulando, em aspectos essenciais, a sua "leitura" de 1977, António José Telo, num prefácio e num artigo recentes $\left({ }^{182}\right)$, manteve que a curta "experiência sidonista" foi, sem dúvida, a grande fonte de inspiração de todo o pensamento da direita portuguesa no século XX e com repercussões além-fronteiras, especialmente no Sul da Europa, mas isso não significa que o regime de Sidónio fosse um "fascismo ou, mesmo, um protofascismo. Obviamente não o era, sendo mesmo duvidoso que, depois das eleições, fosse uma ditadura" $\left({ }^{183}\right)$. O rumo a seguir pareceu-Ihe, pois, o intermédio. Tratou-se, afinal, de um regime marcado por sete importantes elementos da Modernidade: $1^{\circ}$ - a ideia de crise da Nação que justifica a necessidade de ultrapassar as soluções tradicionais e adoptar medidas excepcionais de salvação da Pátria e da República; $2^{\circ}$ - o papel do "chefe" carismático que busca formalmente no sufrágio universal da massa a legitimação do seu anormal poder; $3^{\circ}$ - a tendência de ultrapassar as divisões políticas tradicionais das sociedades liberais anteriores, como seja a divisão entre monárquicos e republicanos, substituindo o primado da denominação e da forma de nomeação do representante máximo da Nação pela aposta na estrutura e nas funções do Estado; $4^{\circ}$ - o entendimento mais lato do papel do Estado na sociedade, cabendo-lhe uma acentuada intervenção nos campos da economia, da assistência social e da segurança; $5^{\circ}$ - a maturidade de um novo conceito de "democracia", diferente da democracia representativa e elitista anterior; $6^{\circ}$ - a noção (ligada ao elemento anterior) de que os partidos não são a forma mais perfeita da representação dos interesses nacionais, sendo de admitir, como alternativa, o sistema corporativo de representação orgânica da sociedade e a presença do chefe como emanação da vontade nacional unitária; e $7^{\circ}$ - a recuperação dos valores tradicionais numa linguagem e numa mítica de salvação nacional e de sacrifício a interesses superiores $\left({ }^{184}\right)$.

Contributo interpretativo interessante e fecundo que peca apenas, em nossa opinião, por se centrar em Sidónio e no Sidonismo. Os

(182) Ver António José Telo, "Sidónio Pais na História", in Miguel Nunes Ramalho, Sidónio Pais diplomata e conspirador (1912-1917), Lisboa, Edições Cosmos, 1998, pp. XI-XVI; e Idem, "Oitenta anos depois. Compreender Sidónio", História, Lisboa, Dez. 1998, pp. 11-25.

$\left({ }^{183}\right)$ Idem, "Oitenta anos depois. Compreender Sidónio", "art. cit.", p. 24.

(1is) Cf. Ibidem, pp. 19-23. 
sete elementos de Modernidade não terão sido antes ínsitos ao próprio republicanismo português, do qual o regime do major-lente foi um curioso epifenómeno? Em caso afirmativo rui pela base a tentativa, mesmo mitigada, de distinguir o Sidonismo do seu contexto essencial e de aproximá-lo das ditaduras de entre guerras, quando essa aproximação cabe, paradoxalmente, à $1^{\text {a }}$ República, embora esta não tenha concretizado a tendência autoritária por força do exemplo dissuasor da III República francesa.

À margem deste profícuo debate, mas de referência obrigatória são ainda os livros de José Freire Antunes e de José Brandão, editados um a seguir ao outro, tendo por pano de fundo conjuntural o eanismo ou a questão do presidencialismo agitada pela classe política portuguesa no final dos anos setenta. O estudo de Freire Antunes intitulado A Cadeira de Sidónio ou a Memória do Presidencialismo prefigurava-se, conforme reza o prefácio, como tentativa de reencontro com um Sidónio diverso do que até então tinha sido pintado: "Este livro não visa fazer de Sidónio nem um herói nem um bandido, e tão-pouco retomar a torpeza da esquerda ou a nostalgia da direita" $\left.{ }^{185}\right)$. Resultou, porém, demasiado híbrido e confuso o intento, convertido mais numa crónica leve e cativante no estilo, urdida a partir da bibliografia conhecida sobre o tema, merecedora dos reparos apontados por Teresa Bernardino( ${ }^{(185)}$ e cuja única novidade é a entrevista com o antigo Ministro da Justiça de Sidónio Pais, o catedrático de Direito Martinho Nobre de Melo( ${ }^{(187)}$.

Uma das impressões controversas que este livro causou foi a de recuperar a "lenda" ou "mito" de Sidónio Pais, considerado liminarmente como o político do século $X X$ português mais amado pelos

(1\$5) Cf. José Freire Antunes, A Cadeira de Sidónio ou a memória do presidencialismo, Mem Martins, Publicações Europa-América, s.d., p. 16.

(186) Ver Teresa Bernardino, "Sidónio o presidencialista", Diário de Notícias, 11 Maio 1982, p. 7. E ainda a polémica que este artigo suscitou, nas páginas do Diário de Lisboa e em Fevereiro de 1982, entre Freire Antunes e o pseudónimo Manuel Lopes Faria (de João Medina?) e o artigo resposta daquele (Diário de Noticias, Fev. 1982, p. 8) ao texto de Raul Rego, "Os Cadetes de Sidónio" (Diário de Notícias, 23 Jan. 1982, p. 8).

(187) Ver José Freire Antunes, A Cadeira de Sidónio, ob. cit., pp. 169-176. Ver também "Confrontar com 53 anos depois a memória de um passado recente". Martinho Nobre de Melo recorda para o Expresso "Os tempos de ministro da Justiça de Sidónio Paes e de ministro dos Negócios Estrangeiros de Gomes da Costa", Revista Expresso, 26 Maio 1979, p. 9-R. 
seus contemporâneos. Este pendor panegirista, denunciado por Teresa Bernardino, foi alvejado por José Brandão numa crítica dura, excessiva até $\left({ }^{188}\right)$. O livro-resposta de José Branđão também não haveria de ficar imune aos defeitos alheios na opinião muito crítica de António Eloy $\left({ }^{189}\right)$.

Avulsas e de valor desigual são as aportações publicadas na revista de divulgação História, rica em artigos monográficos sobre temas dos sécs. XIX e XX. Destacamos o estudo de Maria Cândida Proença respeitante à sobrevivência partidária do Sidonismo após a morte de Sidónio Pais $\left({ }^{190}\right)$, o de Maria Paula Mensurado sobre os Presidentes da República $\left({ }^{19 t}\right)$ e o de Álvaro Garrido intitulado Sidónio Pais: a edificação do mito e centrado na ascensão do político carismático a um estádio de sacralidade, para o qual contribuíram a hierarquia eclesiástica e os católicos em geral, assumindo um importante papel legitimador $\left({ }^{122}\right)$. Na nova série iniciada em 1998 há já dois artigos sobre o Outono fatal de 1918 - a greve geral de 1918 analisada por Alice Samara e o terrivel impacto da gripe pneumónica estudado por Luis Trindade $\left({ }^{193}\right)$.

Ressalvado o valor hermenêutico de algumas das citadas achegas, todas elas ressentem-se negativamente da ausência de um estudo biográfico-histórico sério, exaustivo e se possível interdisciplinar sobre a figura carismática de Sidónio Pais e a sua acção política. A falta de tal estudo foi, aliás, lucidamente observada por Douglas L.

${ }^{(188)}$ Cf. José Brandāo, Sidónio. Contribuiçāo para a história do presidencialismo, Lisboa, Perspectiva \& Realidades, 1983, p. 9; reed. Idem, Sidónio. Tornará feito qualquer outro, Lisboa, Publicações Alfa, 1990, p. 8. Ver também entrevista do autor ao Tempo Magazine: João Isidro, "A Propósito do livro de José Brandão. A Cada época seu sidonismo", Tempo Magazine. Suplemento Tentpo, 14 Jul. 1983, p. 8 .

$\left.{ }^{189}\right)$ Cf. António Eloy, "Sidónio. Contribuição para a história do presidencialismo", Revista Expresso, 24 Set. 1983.

$\left.{ }^{190}\right)$ Ver Maria Cândida Proença, "A Experiência sidonista", História, Lisboa, (63), Jan. 1984, pp. 48-75.

(191) Ver Maria Paula Mensurado, "Os Presidentes da República em Portugal", História, Lisboa, (90/91), Abr.-Maio 1986, pp. 4-41.

(192) Ver Álvaro Garrido, "Sidónio Pais: a edificação do mito", História, Lisboa, ano $16^{\circ}$, Nov. 1994, pp. 38-67.

(193) Ver Alice Samara, "A Greve geral de novembro de 1918. 'O trunto é espadas" $^{\prime \prime}$ História, Lisboa, nova série, 8, Nov. 1998, pp. 28-35; e Luís Trindade, "A Epidemia da greve pneumónica. A morte anunciada", ibident, pp. 36-45. 
Wheeler: "Enquanto não houver um estudo biográfico sério sobre Sidónio Pais, não poderemos compreender o processo que o transformou de unionista interessado na continuação das instituiçōes parlamentares, se bem que com reformas, num determinado presidencialista revolucionário" $\left.{ }^{194}\right)$. Uma lacuna que se lamenta mesmo quando se encontram raras excepções como o guia turísticocultural da inglesa Marion Kaplan sobre Portugal, em que podemos ler umas brevíssimas linhas, mas sóbrias e, em geral, atinadas àcerca da efémera experiência sidonista $\left({ }^{195}\right)$.

Em rigor essa biografia continua a faltar, mas não pode ser ignorado o interesse que João Medina tem consagrado à pesquisa sobre Sidónio e o Sidonismo, perceptível nos incipientes artigos de jornal que publicou no final da década de setenta e corporizado logo a seguir tanto no seminário que dirigiu, a partir de 1980, na Licenciatura de História da Faculdade de Letras da Universidade Clássica de Lisboa e na orientação de dissertações de Mestrado, como em estudos próprios de maior fôlego, embora parcelares, que seriam refundidos e republicados

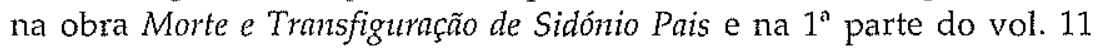
da "sua" História de Portugal. Colaborou, também, na Universidade Aberta na elaboração de um documentário sobre Sidónio Pais, que parte de um confronto interessante do major lente de Matemática com o lente de Direito, futuro e longevo Presidente do Conselho do Estado Novo, doutor António de Oliveira Salazar para melhor acentuar a liderança populista e carismática de Sidónio ${ }^{(96)}$.

Ao nivel do referido seminário conhecemos algumas contribuições avulsas, com interesse do ponto de vista informativo,

${ }^{(194)}$ Cf. Douglas Wheeler, História politica de Portugal, 1910-1926, Mem Martins, Publicações Europa-América, [19-], p. 160.

(195) Ver Marion Kaplan, The Portuguese. The Land and its people, London, A Penguin Books, 1991, pp. 124-125.

(196) Ver Joāo Medina, Sidónio Pais, chefe carismático. Documentário da Universidade Aberta, realizado por José Mexia. Neste trabalho para a Televisão são usadas imagens de época reproduzidas em documentários do Arquivo da R.T.P. e da Cinemateca Portuguesa. Note-se, por outro lado, que no levantamento feito por José de Matos-Cruz Prontuário do cinema português, 1896-1989 (Lisboa, Cinemateca Portuguesa, 1989, pp. 25-27) dos vários filmes aí indicados só está disponível a película Aclamação de Sidónio Pais, $35 \mathrm{~mm}$, realizada por Artur Costa de Macedo. 
mas pouco consistentes no plano hermenêutico: José Manuel de Jesus Vargas no seu trabalho intitulado Sidónio Pais, deputado e ministro (19111912), que permanece inédito, juntou alguns dados sobre essa curta fase da vida de Sidónio, embora. não tenha levado em consideração o contributo de Vítor Braga Paixão( ${ }^{(197}$ ) e concluiu não ter encontrado indícios que permitissem vislumbrar o futuro ditador $\left({ }^{(98)}\right)$; Aida Maria Reis da Mata e José Fernando Vieira Lizardo Gomes Coelho de Oliveira versaram especificamente o terror sidonista, em trabalho também inédito Intranquilidade e repressão no Consulado Sidonista $\left({ }^{199}\right)$, interessante, sobretudo, pela documentação arquivística divulgada e aí referida em apoio da tese de que o Sidonismo desenvolveu um aparelho repressivo proto-fascista; um aparelho que se terá feito sentir em toda a sua força e eficácia face à revolta dos trabalhadores rurais alentejanos, tema do estudo de Francisco Canais Rocha e Maria Rosalina Labaredas $\left({ }^{200}\right) ; c$, por último Fátima Freitas Gomes e Nelson Veríssimo incidiram a sua pesquisa sobre o impacte da governação sidonista no arquipélago da Madeira, sendo interessante o levantamento de dados na imprensa local e em fontes municipais, da Adminsitração do Concelho e do Arquivo Regional, bem como pertinente o relevo conferido à questão das subsistências e ao comportamento das forças apoiantes e da oposição local $\left({ }^{(201}\right)$.

O mesmo não se passa, porém, com a dissertação de Mestrado de José António Sequeira Gonçalves, orientada por João Medina e

${ }^{\left({ }^{197}\right)}$ Ver Vitor Braga Paixão, "A Constituinte de 1911 (Teófilo, Afonso, Sidónio...)", Anais da Academia Portuguesa da Histórin, 2" série, 23 (2), 1976, pp. $36-41$.

(19:) Cf. José Manuel de Jesus Vargas, Sidónio Pais, deputado e ministro (19111912). Trabalho para o Seminário O Sidonismo dirigido pelo Prof. Dr. Joño Medina, 1980/1981, Lisboa, Faculdade de Letras, 1981 (fotocop.).

$\left.{ }^{199}\right)$ Cf. Aida Maria Reis da Mata e José Fernando Vieira Lizardo Gomes Coelho de Oliveira, Intranquilidade e repressão no consulado sidonista, Lisboa, 1981 (fotocop.).

$\left.{ }^{(200}\right)$ Ver Francisco Canas Rocha e Maria Rosalina Labaredas, Os Trabalhadores rurais do Alentejo e o sidonismo, Lisboa, Edições 9 de Outubro, 1982.

${ }^{(201)}$ Cf. Fátima Freitas Gomes e Nelson Veríssimo, A Madeira e o sidonismo, Funchal, Direç̧ão Regional dos Assuntos Culturais/Governo Regional da Madeira, 1983, p. 147. Este estudo foi seguido para o periodo sidonista por Rui Nepomuceno, As Crises de subsistência na história da Madeira. Ensaio histórico, Lisboa, Editorial Caminho, 1994, pp. 182-185. 
intitulada Sidónio Pais e a participação portuguesa na guerra de 19141918, a qual inclui um grosso volume designado por Anexo Documental com uma massa considerável de fontes arquivísticas inéditas tanto de procedência diplomática, como político-militar. A cuidadosa análise dos dados recolhidos e confrontados conduz a conclusões sólidas e coerentes, numa inversão clara da tese germanófila que os guerristas, ainda em 1918, souberam tecer e com ela conseguiram convencer até hoje... Sequeira Gonçalves afirma mesmo que na polémica, então travada, entre Augusto Casimiro e Cunha e Costa era o sidonista quem, afinal, tinha razão, embora se tornasse pouco credível pela maneira como defendeu os seus pontos de vista $\left.{ }^{(202}\right)$. Trata-se, sem dúvida, de uma revelação surpreendente que contraria, no campo historiográfico, os estereótipos forjados pela detracção e infrutiferamente contariados por alguns apologetas. Lamentamos, apenas, que um estudo tão estimulante, apesar de cingido à fase presidencial, não tenha sido ainda publicado, nem sob a forma mais compacta de artigo de revista $\left({ }^{203}\right)$.

Quanto aos estudos e intervenções de João Medina diremos que eles se caracterizam pela variedade dos aspectos focados, por uma substancial erudição histórica ou informativa de tipo essencialmente bibliográfico e periodístico e por um fluxo interpretativo fortemente condicionado pelo pressuposto ditatorial e proto-fascista do "consulado" sidonista, acrescido do pretenso e exclusivo apoio das forças passadistas, retrógradas e socialmente conservadoras, sustentáculo natural e sólido do Estado Novo salazarista. Esta perspectiva está claramente expressa em Sidonismo e Salazarismo( ${ }^{(24)}$ ), em $A$ Resistência dos democráticos durante o sidonismo $\left({ }^{205}\right)$ e no artigo Sidónio Pais, chefe carismático $\left.{ }^{206}\right)$, pensado e

${ }^{\left({ }^{202}\right)}$ Cf. José António Sequeira Gonçalves, Sidónio Pais e a participação portuguesa na guerra de 1914-1918. Dissertaçāo de Mestrado em História Contemporânea de Portugal orientada pelo Professor Doutor Joño Medina, Lisboa, Faculdade de Letras, 1989, fl. 46 (fotocop.).

(203) O seu autor em carta para o jornal Expresso, de 18 de Dezembro de 1993, lamentou o facto e intitulou o texto de um modo assaz sugestivo - Sidónio Pais: una vida mal contada.

${ }^{(204)}$ Ver João Medina, "Da 'República Nova' ao 'Estado Novo'. Sidonismo e salazarismo", História, Lisboa, 3, Jan. 1979, pp. 2-13.

${ }^{(205)}$ Ver Idem, "A Resistência dos democráticos durante o sidonismo", Diário de Noticias, $2^{\circ}$ Cadermo História, 31 Ago. 1982.

(206) Ver Idem, "Sidónio Pais, chefe carismático", Revista da Faculdade de Letras, Lisboa, 5" série, 2, Dez. 1984, pp. 79-89. 
escrito à sombra da teoria de Max Weber sobre a liderança carismática. Parece-nos, aliás, ajustável a noção operatóría de carisma à forte empatia pessoal de Sidónio País e à superlativização emocional do seu papel histórico e político pela generalidade dos cidadãos, mas consideramo-la insuficiente, podendo ser aprofundada pelos dispositivos teóricos da caracterologia e da análise da personalidade, da psicologia social, da psicologia de profundidades e da mitanálise. João Medina tem-se circunscrito, porém, à lição weberiana. Mais conseguida foi, por isso, a sua análise do messianismo consubstanciado no célebre poema de Fernando Pessoa À Memória do Presidente-Rei Sidónio Pais $\left({ }^{207}\right)$. Com interesse informativo é o estudo prosopográfico sobre $O$ Homen que matou Sidónio Pais, embora seja discutível a peremptória afirmação de que José Júlio da Costa protagonizou um "acto isolado" quando as fontes empregues, todas impressas e sobejamente conhecidas, têm uma fiabilidade duvidosa $\left.{ }^{208}\right)$... Oportuníssima foi a transcrição integral do testamento de iniciação maçónica de Sidónio Pais, em 20 de Fevereiro de 1911, na loja Estrela d'Alun de Coimbra $\left({ }^{209}\right)$. E, por último, registamos os estudos que consagrou às relaçōes ou reacções de Manuel Teixeira Gomes, António Sérgio e João Chagas ao regime sidonista $\left({ }^{210}\right)$, interessantes pelo aparato erudito em que assentam.

(207) Ver Idem, "Fernando Pessoa e o messias: sobre a visão messiânica de Pessoa e o seu ideário político", in Encontro Internacional de Fernando Pessoa. Actas do colóquio "Um Século de Pesson", Lisboa, 1990, pp. 229-239; retomado e revisto em Iden, História de Portugal, vol. 11, ob. cit., pp. 11-32.

${ }^{(20 x)}$ Ver Idem, "O Homem que matou Sidónio Pais", História, Lisboa, 10, Agosto 1979, pp. 41-56. Poucos anos depois foi publicado num diário da capital um artigo sinóptico sobre o assassínio de Sidónio Pais: Victor Mendanha, "Presidente da República assassinado em Lisboa. A Política de Sidónio", Correio da Manhã, Mar. 1984, pp. 28-29.

${ }^{(2 n 9)}$ Ver Joāo Medina, "Um documento inédito. O Ingresso de Sidónio Pais na Maçonaria", Diário de Lisbon, 26 Jan, 1981, pp. 3-4. Sobre esta faceta do seu curriculum vitae ver o verbete PAIS, Sidónio Bernardino Cardoso da Silva, in A. H. de Oliveira Marques, Dicionário de Maçonaria portuguesa, vol. $2 \mathrm{~J}-\mathrm{Z}$, Lisboa, Editorial Delta, 1986, cols. 1075.

$\left.{ }^{210}\right)$ Ver João Medina, "Manuel Teixeira Gomes e Sidónio Pais", Clio, Lisboa, 2, 1980, pp. 117-129; Idem, "João Chagas entre dois ditadores", Diário de Lisbon, 10 Mar. 1981; e Idem, "Sérgio e Sidónio. Estudo do ideário sergiano na revista Pela Grei (1918-1919)", in Iden, Sérgio Campos Matos e António Ventura, Estudos sobre António Sérgio, Lisboa, Centro de História da Universidade de Lisboa/Instituto Nacional de Investigaçāo Científica, 1988, pp. 7-30. 
No mesmo registo monográfico e parcelar merecem ainda relevo os trabalhos de Luís Farinha e de Miguel Nunes Ramalho( $\left.{ }^{211}\right)$. Ambos revisitaram Sidónio Pais em Berlim e desmontaram, com base no exame minucioso da informação arquivística disponível, nāo só o equivoco intencional ou acidental de David Ferreira sobre a alegada tendência germanófila de Sidónio Pais, mas também a caricatura leviana ou malevolamente esboçada por João Chagas, segundo a qual o ministro de Portugal em Berlim nada fizera de útil, exibira uma conduta totalmente reprovável e, pior ainda, regressara deixando os cônsules portugueses como reféns para garantia de que aos homólogos germânicos de Moçambique e de Angola fosse dado transporte para país neutro $\left({ }^{212}\right)$.

A suposta inépcia e apatia do diplomata português surge também claramente refutada num estudo que tivemos o ensejo de fazer àcerca das relações diplomáticas entre Alemanha e Portugal no alvores do séc. XX e à luz da correspondência consular portuguesa( $\left.{ }^{213}\right)$.

\section{Um contributo para o (re)orientação historiográfia em curso}

Esse e muitos outros aspectos foram revisitados por um projecto de pesquisa de certo fôlego que tivemos ocasião de realizar $\left.{ }^{(214}\right)$ e que parte de enquadramento teórico reformulado graças a alguns pertinentes contributos da produção historiográfica até ao momento acumulada. Parece-nos oportuno adiantar aqui as suas linhas-mestras.

Se atendermos principalmente ao(s) enfoque(s) da componente

(211) Ver Luís Farinha, "Sidónio Pais em Berlim", História, Lisboa, 16, nova série, 2, Nov. 1994, pp. 28-37; e Miguel Nunes Ramalho, Sidónio Pais diplonnata e conspirador (1912-1917), Lisboa, Edições Cosmos, 1998.

${ }^{(212}$ Esta versão foi veiculada pelos adversários políticos do Sidonismo, como, por exemplo, Artur Leitāo, Situnçāo política. Cartas a um conselheiro da república e resposta de sua excelência, Coimbra, Tipografia França Amado, 1918, p. 11.

${ }^{(213}$ ) Ver Armando B. Malheiro da Silva, "A Alemanha no princípio do século $X X$ à luz da correspondência consular portuguesa", in Marília dos Santos Lopes, Ulrich Knefelkamp, e Peter Hanenberg (org.), Portugal und Deutschland auf dem Weg nach Europa/Portugal e a Alemanha a caminho da Europa, Pfaffenweiler, Centaurus-Verlagsgesellschaft, 1995, pp. 47-67.

${ }^{(214)}$ Ver Idem, Sidónio e sidonismo. História e mito, dissert. cit., e Idem, "Síntese do Projecto Sidónio e Sidonimso. História e Mito", Itinerarimm, Braga, 45, 1999, pp. 501-524. 
política do processo histórico do republicanismo em Portugal ressalta logo o simplismo redutor das visões ideológicas antagónicas a que se seguiu o predomínio da matriz socio-económica. Então, o político e os mecanismos de aç̧ão e de reprodução do Poder ficaram embutidos nessa nova matriz directora, cujas limitações adquirem, por sua vez, particular nitidez no caso da experiência sidonista. Com efeito, resulta assaz insuficiente entendê-la numa linha marcada quase só pelas características e vicissitudes do desenvolvimento capitalista e pela estruturação das classes possidentes, pelas tensōes entre diferentes sectores da grande burguesia e pela interacção estratégica da burguesia colonial, sector agrário e campesinato num sentido vincadamente conservador. Seguir por esta via, tendo em vista a descoberta, no efémero fenómeno manifestado ao longo do crítico ano de 1918, dos sintomas agudos da agonia e morte do Estado liberal burguês e dos gérmens do futuro Estado Novo, constituiu para determinada historiografia um exercício geométrico e aliciante. No entanto, fácil é reconhecer que não se deve escamotear por muito mais tempo o óbvio ou complicar o simples: se, como a generalidade dos autores têm sublinhado, o Sidonismo findou com a morte de Sidónio Pais - o que desde logo significa a presença de uma superlativa função pessoal no figurino presidencialista da República Nova - ao princípio era o homem, as suas origens, as suas circunstâncias e a sua evolução dentro do respectivo quadro geracional, histórico, sócio-cultural e mental, quadro esse essencial, aliás, para apreendermos, em larga medida, o sentido da $1^{\text {a }}$ República.

Impõe-se, assim, o primado histórico-biográfico dentro de uma reorientação metodológica que, sem negar a efectiva influência do Sidonismo na conjuntura posterior e, sobretudo, das representações que dele ficaram em certos estratos sócio-económicos e em certas instâncias militares, culturais e ideológico-políticas, obrigue primeiramente a olhar para trás e não para a frente... Enfim, obrigue a procurar em Portugal, na Europa e no Novo Mundo finissecular de oitocentos as bases matriciais da ditadura dezembrista e da fase sidonista propriamente dita. Esta pode ter servido de inspiração a certas forças e a potenciais ideólogos com carreira promissora no período entre guerras, mas este facto não autoriza que estabeleçamos analogias directas e definitivas entre a República Nova e o Estado Novo, esquecendo o processo de implantação e de evolução da ideia republicana. 
É dentro da $1^{\text {a }}$ República e da sua génese que Sidónio Pais e o Sidonismo encontram plena inteligibilidade, pelo que os seus traços, mesmo os mais conformes com os requisitos politológicos do fascismo - anti-parlamentarismo, populismo plutocrático, corporativismo, forte repressão policial, uso e abuso da censura à imprensa, etc. - remetem cabalmente para as aspirações, as tensões, as contradições, as ambiguidades e as ambivalências do movimento republicano português, muito estimulado, como é sabido, pela fracassada tentativa reformista e, segundo Fernando Rosas e José Miguel Sardica, precocemente autoritária do franquismo.

Parece-nos, em face disto, discutível que, conforme escreveu Amadeu Carvalho Homem, as ditaduras do general Pimenta de Castro, em 1915, e de Sidónio Pais, em 1917, tenham representado ataques objectivos à filosofia política subjacente à $1^{\mathrm{a}}$ República (entendido o 5 de Outubro como a transição de um liberalismo clássico para um sistema político demo-liberal...) e prefigurações da ditadura militar de 1926, a partir da qual se gerou "o cinzento e cabisbaixo interregno do Estado Novo" $\left.{ }^{215}\right)$.

Admitimos, pois, uma hipótese alternativa, esquematizada sobretudo nos seus contornos político-institucionais e ideológicopolíticos e destinada a abrir ainda mais o debate, nunca a fechá-lo.

O populismo, a figura de um chefe carismático e o antiparlamentarismo são, sem dúvida, traços da República Nova que tiveram continuidade a nivel europeu nas duas décadas seguintes e que foram apropriados como herança específica do Estado Novo. No entanto, o que tem sido aceite como uma evidência, reduz-se, talvez, a pouco mais que um "erro óptico": esses traços "proto-fascistas" do Sidonismo não podem ser descontextualizados, desinseridos do quadro ideológico e político da $1^{a}$ República e da segunda metade do séc. XIX, isto é, a sua inteligibilidade histórica e historiográfica está para trás e não para a frente.

A nossa hipótese, fixada em esquema, parte, pois, desta mudança de perspectiva e consiste em demonstrar que Sidónio Pais foi, dentro dos seus particularismos psicobiográficos, um republicano e um democrata e que o dezembrismo/sidonismo não representou

(215) Cf. Amadeu Carvalho Homem, "Identidade nacional e contemporaneidade", Revista de História das Ideias, Coimbra, 17, 1995, p. 595. 
qualquer tipo de ruptura ou de alteração substancial relativamente à matriz ideológico-política e político-institucional em que surgiu. Feita esta elementar demonstração abre-se fecunda e promissora a análise histórica e politológica em torno da queda da "Nova República Velha", do sentido inicial da Ditadura Militar e do eventual contributo dos sidonistas e da sua "herança política" na construção do Estado Novo.

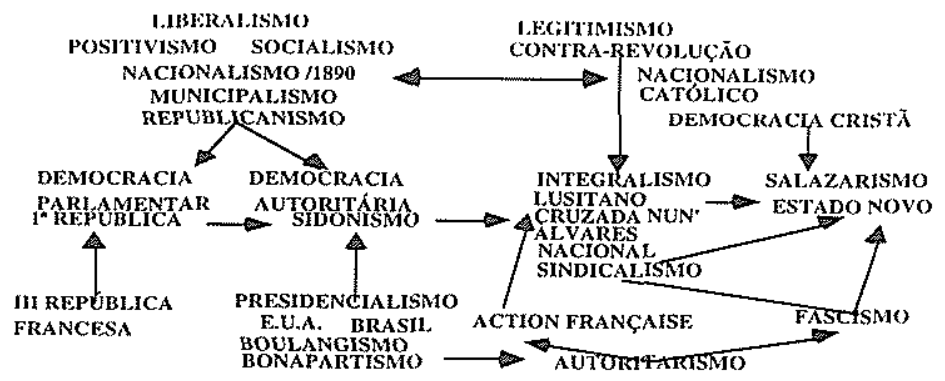

A reorientação historiográfica que propomos inscreve-se assumidamente dentro das "fronteiras" de uma História Política reabilitada e renovada, tal como a enunciou e a tem praticado René Rémond e os seus discípulos $\left({ }^{216}\right)$ ou ainda como a explicou e enfatizou na componente metodológica Pierre Rosanvallon em artigo de 1986 e recentemente divulgado pela revista paulista Histórin( $\left.{ }^{217}\right)$. Assim reconfigurada, a História Política é a instância epistemológica certa para o reexame crítico e revigorado do caso Sidónio Pais e da sua Repriblica Nova, porque permite inserir a vertente biográfica na análise e descrição do processo político republicano, abarcando uma grande diversidade de aspectos e de temas correlativos.

Um deles é, aliás, a questão partidária e importa, desde já, sublinhar que durante o rotativismo monárquico prevaleceram os chamados "partidos de notáveis ou caciques" (patrocinato político), construídos a partir de "cima" e reduzidos, no essencial, a "coligações mais ou menos coesas de redes dispersas de notáveis locais, agregadas

(216) Cf. René Rémond, "Une histoire présente", in Idem (dir.), Pour une histoire politique, Paris, Éditions du Seuil, 1988, pp. 31-32.

(217) Ver Pierre Rosanvallon, "Para uma história conceitual do político (Nota de estudo)", História, São Paulo, 15, 1996, pp. 27-39. 
segundo uma lógica de cooperação vertical e orientadas para o controlo e a distribuição particularista dos recursos do centro político" $\left({ }^{218}\right)$, e que, com o advento do Partido Republicano Português (P.R.P.), emergiu um modelo partidário de maior grau de institucionalização e diferenciação, dinamizado por redes ou networks $\left({ }^{219}\right)$ sócio-políticas mais coesas, mais "burocratizadas" e mais sensíveis à penetração do centro na periferia, embora indelevelmente marcadas pelas práticas de patrocinato e de compadrio patentes na sociologia e na geografia das eleições legislativas anteriores ao 5 de Outubro $\left({ }^{220}\right)$.

Nesta ordem geral de pressupostos não foi privilegiada propriamente a biografia, atendendo aos subtis e exigentes requisitos de um género durante muito tempo menorizado pela leitura distorcida dos princípios da Nova História e pelo ocaso temporário da História Política, mas tāo só uma análise histórica de incidência psicobiográfica.

(21s) Cf. Pedro Tavares de Almeida, Eleiçōes e caciquismo no Portugal oitocentista (1868-1890), Lisboa, Difel, 1991, p. 122. Sobre a caracterização das relaçōes estabelecidas entre os caciques ou notáveis e os seus dependentes, relações essas que definiam um tipo particular de interacção social, historicamente configurado no modelo de relações patrono-cliente ver Ibidem, p. 132

${ }^{(219)}$ Boot, em 1971, definiu network como qualquer tipo de entidade social ou grupal de referência ou de aplicação conceptual à realidade concreta.

${ }^{(220)}$ No que concerne à aplicação teórica da noção de redes (networks) e "constelações" (clousters) ao processo político ver as contribuiçōes seminais do antropólogo britânico J. A. Barnes, "Class and committees in a norwegian island parish", Human Relations, 7 (1), Feb. 1954, pp. 39-58; Idem, "Networks and political process", in M. J. Swartz (ed.), Local level politics: social and cultural perspectives, Chicago, Aldiva, 1968; e Idem, Social networks, Massachusetts, Addison-Wesley Module, 1972. Outras contribuiçōes posteriores visaram dar consistência a esta utensilagem conceptual e metodológica: Barry Markovsky, David Willer e Travis Patton, "Power relations in exchange networks", American Sociological Review, 53, Apr. 1988, pp. 220-236; John Scott, "Report social network analysis", Sociology, 22(1), Feb. 1988, pp. 109-127; e David Knoke, "Networks of political action: toward theory construction", Social Forces, Chapel Hill, 68(1), Jun. 1990, pp. 1041-1063. A luz destes estudos mais recentes inferese facilmente a articulação dessas noções com a teoria sistémica da política, bem sintetizada por Miguel Artola na sua volumosa e fundamental obra Partidos y programas politicos, 1808-1936, 2 vols. (Madrid, Alianza Editorial, 1991). E sobre o funcionamento das redes clientelares no liberalismo oitocentista português ver com proveito Pedro Tavares de Almeida, Eleiçōes e caciquismo no Portugal oitocentista (1868-1890), ob. cit., pp. 119-189. 
E não se trata de uma mera nuance retórica: com o concurso disciplinar da genealogia, da psicologia, da psicobiografia ou da psicanálise histórica ${ }^{(221)}$, além, claro está, do elementar contributo historiográfico em todas as facetas implicadas pela trajectória da vida de Sidónio Pais, assentamos numa descrição minuciosa, delineada pelo cruzamento dos abundantes dados disponíveis através de uma morosa e exigente pesquisa documental. Em linguagem forense e judiciária dir-se-ia que nos interessou, sobretudo, exibir as "provas" de uma vida e do seu contexto, mesmo correndo o risco de uma narrativa de anacrónico "sabor" positivista. Basta, porém, compulsar o que existe escrito sobre Sidónio Pais, condensado, aliás, nos pontos anteriores, para se compreender a urgência de um trabalho de cabouqueiro, fastidioso, extenso, mas indispensável, para que fiquem a descoberto as bases ocultas ou ignoradas sobre as quais tem de fluir a(s) biografia(s) propriamente dita(s) que Sidónio sem dúvida justífica, como a justificam, aliás, os restantes protagonistas políticos do Portugal contemporâneo, quase todos, sem exagero, à espera ainda de biografias libertas das pechas tradicionais - a hagiografia ou a detracção, mais ou menos disfarçadas!...

Vimos atrás o interesse historiográfico suscitado pelo carisma de Sidónio e pela respectiva "lenda", para muitos sinónimo de mito, aspecto dos mais salientes não apenas do Sidonismo, mas de toda a política portuguesa ao longo deste século. Não podíamos, por isso, desprezá-lo, até porque, em nossa opinião, se impõe aqui, também, uma reorientação "profiláctica".

É preciso que nos entendamos quanto ao conceito operatório de mito e façamos, desde já, as nossas opções. Convém, por isso, frisar antes de mais que a percepção da dimensão mítica pressupõe a ideologia e a cultura, pressupóe a espessura ideologémica patente nos mais díspares

(221) Sobre a natureza teórico-metodológica da psicobiografia, da psicohistória ou da também designada psicanálise histórica ver: Saul Friedlander, Histoire et psychanalyse. Essai sur les possibilités et les limites de la psychohistoire, Paris, Editions du Seuil, 1975; Rudolph Binion, Introduction à la psychohistoire, Paris, PUF, 1982; Lloyde de Mause, Les Fondations de la psychohistoire, Paris, PUF, 1982; Jacques Szaluta, La Psychohistoire, Paris, PUF, 1987; William Mckinley Runyan (edit.), Psychology and historical interpretation, New York/Oxford, Oxford University Press, 1988; e Elisabeth Young-Bruehl, Psychoanalysis and biography, in Idem, Mind and the body politic, New York, Routledge, 1989, pp. 138-154. 
"registos" (oratória política, parenética, literatura, iconografia, cinema, etc.), ou seja, a esfera da(s) racionalidade(s) impregnada(s) de simbólico.

Conjunto de imagens ou emanação de um imaginário só em parte inscrito na esfera racional, porquanto também radicado no genótipo da espécie humana, o simbólico, segundo Jean-Jacques Wunenburger, só no mito se deixa apreender bem. E acrescenta: "A travers le symbolique nous expérimentons que nous sommes pas la source de toutes nos représentations et qu'elles ne sauraient toutes gagner à accéder à la pleine lumière rationnelle. La symbolicité des images nous confronte donc à une altérité qui nous rapelle notre propre finitude. Elle nous met face à un autre langage que celui dont nous croyons généralement être l'auteur" (222). Sugere, pois, este autor que as imagens ou símbolos implicam um nível profundo, implicam a operatividade do inconsciente colectivo e arquetipal postulado por Carl Jung $\left({ }^{(223}\right)$, do qual se aproximou, apesar de certas cautelas e reservas, o consagrado historiador das mentalidades Philippe Ariès $\left({ }^{224}\right)$ e ao qual

(222) Cf. Jean-Jacques Wunenburger, La Vie des images, Strasbourg, Presses Universitaires de Strasbourg, 1995, p. 27.

(223) Sobre as noçōes de imagem, símbolo e inconsciente colectivo que operam no pensamento jungiano vale a pena atentar na sinopse explicativa, simples e muito didáctica, de Pierre Daco: "Haveria pois um Inconsciente Superior que seria o mesmo para todos os homens. Observemos uma pessoa cuja razão crítica é cortada por qualquer meio (sonho nocturno, emoção, inspiraçāo artística, transe de médium, certas sessōes de psicanálise, etc.). Verificamos então uma coisa perturbadora. Tudo se passa como se os homens modernos tivessem no fundo de si próprios as recordações emotivas dos seus longínquos antepassados. Como estes, o homem moderno emprega as mesmas imagens e os mesmos símbolos profundos, que dir-se-iam serem uma herança mental, comum a toda a Humanidade, sem distinção de cultura nem de raça. Não é incrível, que certos assuntos de lenda se repitam, em todo o Mundo, em formas idênticas? Para os encontrar em toda a sua pureza, há que estudar as religiōes, as mitologias, as lendas populares, o folclore. Mas só falo aqui de psicologia prática. Encararei, por isso, estes símbolos como um fim de cura. Far-nos-ão voltar ao âmago do homem. A sua significaçāo é grandiosa. E se bem que o estado consciente nos leve a esquecê-los, nem por isso estarão menos presentes. Agem na sombra, em plano recuado da consciência" (Cf. Idem, As Prodigiosas vitórins da psicologia moderna, vol. 1, Lisboa, Portugália Editora, 1971, pp. 318-319).

(224) Ver Michel Vovelle, Idéologies et mentalités, Paris, Libraire François Maspero, 1982, pp. 86-96. 
parece abrir-se o "paradigma indiciário" proposto por Carlo Ginzburg(225).

Os arquétipos são imagens primordiais e universais relacionadas com o "cérebro emocional" - expressão de Daniel Goleman $\left(2{ }^{26}\right)$, fundada nos resultados actuais da Neurobiologia ou Neurociência - e compõem as multisseculares narrativas mitológicas, unidades simbólicas que combinam e articulam o indizível e o dizível, a verbalização, o discurso...

Todo o mito é, pois, uma narrativa, um discurso de tempo circular que precede e contraria o sentido finalista da História (é, nesta acepção, uma não-História), mas que também se projecta e prolonga no tempo linear histórico introduzido pela concepção judaico-cristã. Coexiste, pois, com a História, invadindo-a amiúde, através da recorrência, ressurgência ou latência mítica, função pressentida há muito pelos filósofos e pelos poetas (através da "mitopoiética", definida por Douglas Davies pela "capacidade de imaginaçăo humana de produzir mitos, deveras importante para o campo dos estudos religiosos" $(227))$, mas que só neste século e graças aos estudos de Georges Dumézil, Gaston Bachelard, Carl Jung e Mircea Eliade se tornou conceptualmente operativa e postulada pela sociologia do imaginário e, em particular, pela mitanálise de Gilbert Durand.

O contributo mitanalítico durandiano é, por tudo isto, considerado remitologizador e oposto à concepção expressa por Roland Barthes $\left({ }^{228}\right)$, na medida em que não banaliza o mito, não o reduz, no plano discursivo, a mera "manipulação" metafórica da realidade, a mera lenda, ficção, fantasia, efabulação... Insiste, pelo contrário, em recuperar e aprofundar a "lição" de Eliade.

O mito é uma narrativa que conta uma história verdadeira, exemplar e significativa, logo sagrada ou, caso se queira, inscrita num tempo sagrado, imemorial. O mito conta uma história

(2.25) Ver Carlo Ginzburg, "Traces. Racines d'un paradigme indiciaire", in Idem, Mythes, emblèmes, traces, ob. cit., pp. 139-180.

(226) Ver Daniel Goleman, Inteligência emocional, Lisboa, Círculo de Leitores, 1995, pp. 31-34.

$\left.{ }^{227}\right)$ Cf. Douglas Davies, "Introdução. Abordagem ao tema", in Jean Holm e John Bowker, Mito e história, Mem Martins, Publicações Europa-América, 1997, p. 18.

${ }^{(228)}$ Ver Roland Barthes, Mitologias, Lisboa, Edições 70, 1973, p. 182. 
sagrada $\left({ }^{229}\right)$; ele relata um acontecimento que teve lugar no tempo primordial, o tempo fabuloso dos começos; o mito conta como, graças às explorações dos seres sobrenaturais, uma realidade veio à existência, trate-se da realidade total, o Cosmos, trate-se somente de um fragmento - uma ilha, uma espécie vegetal, um comportamento humano, uma instituição; é sempre, portanto, a narrativa de uma criaçāo; os mitos descrevem as diversas e, por vezes, dramáticas irupções do sagrado (ou simplesmente a sobre-naturalidade) das suas obras. Em síntese, o mito é caracterizado por relatar a história dos actos dos seres sobrenaturais, por ser uma história verdadeira porque se refere a realidades e sagrada porque ela é obra dos seres sobrenaturais, e por "relatar" sempre uma criação. Aquele que conhece o mito conhece automaticamente a origem das coisas e, por isso, controla-as. Vive-se o mito no sentido em que a sua numinosidade, a sua potência sagrada apalavra aquele que o conhece e vive $\left({ }^{230}\right)$.

Acrescente-se que esta noção de mito, ao contrário do que opinam Marc Lits e Gabriel Ringlet ou, na peugada destes, Mário Mesquita ${ }^{(231)}$, continua a funcionar na realidade, mesmo se aplicada a figuras dos dias de hoje consideradas míticas ou designadas por "mitos

$\left.{ }^{(229}\right)$ Ver neste sentido a criação e fixação do mito nas mais diversas religiões da Humanidade - budismo, hinduísmo, siquismo, islamismo, judaísmo, cristianismo, religiōes chinesas e religiōes japonesas, in Jean Holm e John Bowker, Mito e histórin, ob. cit., p. 25 ss.

${ }^{(230)}$ Cf. Mircea Eliade, Aspects du mythe, Paris, Gallimard, 1991, p. 15.0 próprio Mircea Eliade e também Pierre Riffard (Dicionário do esoterismo, Lisboa, Editorial Teorema, 1993, p. 325) conseguiram condensar as características e propriedades num elenco significativo de termos: o mito é uma narrativa real (pretende ser uma revelação), sagrada (narra obras divinas, santas), eterna (desenrola-se no tempo sagrado das origens), exemplar (serve de modelo para a acção humana), repetitivo (pode ser repetida e reactualizada por intermédio de ritos) e ainda paradigmática, transpessoal e significativa. Para além disto, JeanPierre Sironneau ("Retour du mythe et imaginaire socio-politique", in Le Retour du Mythe, Grenoble, Publications Universitaires de Grenoble, 1980, pp. 14-15) observou que o mito está dotado de funções particulares, a saber: a cognitiva, diferente da explicação racional, mas incontestável; a sociológica, que legitima a ordem social; a psicológica, que é a expressão dos conflitos inconscientes da psiché; e a ontológica, que enraiza a condiçāo humana num arquétipo transcendente.

(231) Ver Mário Mesquita, "O Performismo cerimonial. Da praça pública à televisāo", Revista de História das Ideias, Coimbra, 15, 1993, p. 604. 
modernos" - De Gaulle, Brigitte Bardot, Elvis Presley, os Beatles, Maradona, Princesa Diana ou mesmo o automóvel... -, porque tais figuras são heroicizadas e tais objectos idolatrados através de novos recursos discursivos e ideologémicos de legitimação, mas que, afinal, decalcam, na essência, as velhas narrativas mitológicas, nomeadamente as de tradiçāo greco-romana e judaico-cristã.

A miragem de novas mitologias e de novos rituais (as cerimónias públicas mediatizadas pelos meios audiovisuais de comunicação) foi questionada de forma, em nossa opinião, pouco conseguida pelo historiador Raoul Girardet, que considerou a Conspiração, o Salvador, a Idade do Ouro e a Unidade como velhas mitologias de algumas ideias-força da política contemporânea $\left({ }^{232}\right)$. Confundiu, assim, tema e mitologema, arquétipo e mito e não clarificou os conceitos, o que, do ponto de vista do rigor da análise científica, é contraproducente.

Mais sólido e rigoroso no plano conceptual é o contributo analítico dos durandianos e, em especial, de Jean-Pierre Sironneau, que conseguiu demonstrar, no seu trabalho de maior fôlego $\left({ }^{233}\right)$, que a secularização contemporânea não produz mitologias originais, antes se nutre da ressurgência ou recorrência dos velhos mitos. Este sociólogo e especialista do imaginário, sobretudo na sua vertente sócio-política e religiosa, pôs em relevo alguns aspectos fundamentais.

Em primeiro lugar, há a articulação natural do mito com a religião, de que resulta uma mediação do sagrado, transferida substancialmente pelas ideologias para a esfera sócio-política, bem evidenciada por Sironneau através da análise interna das grandes ideologias da Modernidade - liberalismo, nacional-socialismo, fascismo e comunismo - designadas por "religiões políticas" e geradas no seio da secularização pós-iluminista, que começou por implicar uma "relativa dessacralização" com a Revolução Francesa para, de seguida, se verificar a ressurgência do religioso através de uma absolutização

(232) Ver Raoul Girardet, Mythes et mythologies politiques, Paris, Seuil, 1986.

${ }^{(233)}$ Ver Jean-Pierre Sironneau, Sécularisation et religions politiques, Paris, Mouton, 1982. Ver, também, Idem, "Eschatologie et décadence dans les 'religions politiques", Decadence et Apocalypse, Dijon, 1, 1986, pp. 97-118; Idem, "Les équivoques de la réligion révolutionnaire", in Mythes et révolutions, Grenoble, Publications Universitaires de Grenoble, 1990, pp. 99-132; e Idem, Figures de l'imaginaire religieux et dérive idéologique, Paris, L'Harmathan, 1993. 
do político, ou seja, uma absorção na esfera política de atitudes e de aspirações tradicionalmente ligadas à esfera religiosa. Em segundo, sobressai a substancialização do mítico como "realidade simbólica", isto é, como um outro nível da realidade, mais complexa, mais profunda ou menos imediata e, por conseguinte, irredutivel ao cultural, ao psicológico ou ao sociológico, enquanto níveis duma realidade exterior mais facilmente perceptível ou observável. E, em terceiro lugar, há que reconhecer a vitalidade da universalização do mítico, que torna possivel, por exemplo, a existência na esfera sócio-política de mitos fundadores com o mesmo tipo de funcionamento e de estrutura porquanto reenviam para a mesma tradição mitológica - a egípcia, a greco-romana, a judaico-cristã, etc. Não faltam, aliás, exemplos $\left({ }^{(234}\right)$ : os antigos judeus acreditavam na felicidade de Israel, na sua superioridade, por favor divino, em relação às outras nações; os fundadores da Nação americana acreditavam não só que ela era determinada pela Providência, mas também que ela merecia existir e ser chamada a um futuro grandioso; por seu turno, a memória mítica dos reis dos Francos desenvolveu-se do séc. VI ao séc. XII, enraizando nela a "continuidade" das três dinastias: "Parallèlement à l'extension de sa domination territoriale et politique, le roi, désormais, condense dans sa personne des pouvoirs miraculeux, que célèbre une religion royale" $\left({ }^{235}\right)$; e, no caso português, avulta o milagre de Ourique, semelhante aos exemplos anteriores pela tradição mitológica comum (judaico-cristã), pela marca providencialista, pelo predomínio das estruturas messiânicas ou escatológicas $\left({ }^{236}\right) \ldots$

A revalorização, cerca de um século e meio após os efeitos demolidores da crítica histórica de Alexandre Herculano $\left({ }^{237}\right)$, do

(234) Ver, a este propósito, Léon Poliakov, Le Mythe aryen, Bruxelles, Éditions Complexe, 1987 ( 1 " ed. 1971); e Idem, "Les Sources du racisme", Iris. Mythe et Nation, Grenoble, 15, 1995, pp. 21-26.

${ }^{(235)}$ Cf. Françoise Citron, Le Mythe national. L'histoire de France en question, Paris, Éditions Ouvrières/Études et Documentation Internationales, 1987, p. 121.

(236) Sobre isto ver Alberto Araújo e Armando Malheiro da Silva, "Afonso Henriques, o mito fundador e a recorrência mítica. Para uma mitanálise do processo histórico português", in $2^{\circ}$ Congresso Histórico de Guimarāes, vol. 3, ob. cit., pp. 325-337.

${ }^{(237)}$ Sobre o assunto ver Ana Isabel Carvalhão Buescu, O Milagre de Ourique e a História de Portugal de Alexandre Herculano. Uma polémica oitocentista, Lisboa, Instituto Nacional de Investigação Científica, 1987. 
milagre de Ourique como mito fundador da Nação portuguesa decorre da perspectiva mitanalítica exposta e obriga, entre outros aspectos, a reduzir o Sebastianismo às proporções de tema mítico inscrito, quanto ao essencial, na simbólica do referido milagre, genuína narrativa fundacional ou de criação...

Face ao exposto, o caso de Sidónio Pais só indirectamente convoca a dimensão mítica. Antes de mais trata-se de uma personalidade com características de liderança e de afirmação apaixonada de ideias, valores e sentimentos. Uma personalidade que se ajusta em pleno à noção weberiana de carisma e melhor ainda ao "fenómeno carismático" reexaminado, entre outros, pelo antropólogo americano Charles Lindholm $\left({ }^{238}\right)$. Um fenómeno que exige, porém, circunstâncias históricas e colectivas próprias. E só neste âmbito mais complexo é que o mito irrompe através da interacção da República prometeica e milenarista e o Portugal católico, profundo e messiânico, plasmado no milagre de Ourique. Do ponto de vista mitanalítico há, aliás, uma diferença subtil, mas importante, entre milenarismo e messianismo abordada em trabalho de maior fôlego ${ }^{(239)}$.

A tensão mítica atingirá o paroxismo com o milagre de Fátima. Villaverde Cabral ou ainda Vasco Pulido Valente referem-se-lhe como uma "operação" montada pelos sectores anti-afonsistas, conservadores, católicos, etc., e ao fazê-lo encerram o mítico-simbólico no domínio estrito das racionalidades, numa perspectiva inversa à do atrás citado Jean-Jacques Wunenburger. Esse aparatoso milagre ocorreu precisamente ao longo de 1917, o ano da "revolução" de Dezembro e interagiu em profundidade com o processo político subsequente.

Numa perspectiva mitanalítica pode dizer-se que a conjuntura histórica balizada entre 1890 e 1926 correspondeu a um forte período

(238) Ver Charles Lindholm, Carisma. Análisis del fenómeno carismático y su relación con la conducta humana y los cambios sociales, Barcelona, Gedisa Editorial, 1992; e ainda, Luciano Cavalli, Il Capo carismatico. Per una sociologia weberiana della leadership, Bologna, Il Mundo, 1981; Arthur Schweitzer, The Age of charisma, Chicago, Nelson-Hall, 1984; Ronald M. Glassman e William H. Swatos Jr., Charisma, history and social structure, New York, Greenwood Press, s.d.; e Ann Ruth Willner, The Spellbinders charismatic political leadership, New Haven/ London, Yale University Press, s.d.

${ }^{(239)}$ Ver Armando Barreiros Malheiro da Silva, Sidónio, Sidonismo. História

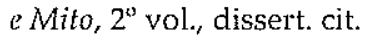


de ressurgência mítica forjada, obviamente, por todas as condições determinantes, como as económicas, as sociais, as psicológicas, as culturais e as ideológicas. Dai que a $1^{\text {th }}$ República tenha emergido associada à vaga das estruturas antropogónicas e das cosmogónicas, que desde, pelo menos, o séc. XVIII "actualizam" mitos como o de Prometeu ou o da Idade do Ouro, subsumidos na ideia-força de Progresso, e os mitos do Fim do Mundo implícitos na ideia-força de Decadência $\left({ }^{240}\right)$. Em acentuado declínio desde a Restauração( $\left.{ }^{(21)}\right)$ estava o mito de Ourique, animado pelas estruturas escatológicas e sujeito a algumas alteraçōes arquetípicas significativas, principalmente a ascensão da Virgem Maria (regime arquetipal da Mulher/Anima) como Padroeira do Reino, substituindo, em Fátima, Jesus Cristo, seu Filho (regime arquetipal do Animus, imago masculina, patriarcal) na relação dialógica e providencialista com Portugal, "nação eleita e protegida" descle a memorável aparição a Afonso Henriques, o rei fundador.

É, pois, este, em breves traços, o quadro da tensão míticosimbólica, intuído poeticamente por Fernando Pessoa, enquanto vate esotérico e discípulo do $P^{e}$ António Vieira, quadro esse em que Sidónio Pais, meteoricamente, apareceu e desapareceu numa trajectória equívoca e muito interessante: como jacobino, positivista, cientista e republicano, não obstante a sua formação militar e politécnica, recebida na Escola do Exército, e académica, desenvolvida na Universidade de Coimbra, aderira emocionalmente ao milenarismo e à (ante)visão prometeica republicana; mas ao opor-se pessoalmente, como chefe supremo num regime presidencialista, ao pretenso radicalismo dos democráticos de Afonso Costa, ao devolver espaço de manobra ao Portugal rural, conservador e católico, suscitou equívocos e provocou fracturas insuperáveis - será demonizado por muitos republicanos e heroicizado, sacralizado pelo messianismo católico. Ele que até à morte se conservou agnóstico!...

(2410) Ver Maria Teresa Pinto Coelho, Apocalipse e regeneração: o Uttimatum e a mitologia da Pátria na literatura finissecular, Lisboa, Ediçōes Cosmos, 1996, pp. 17-18.

(241) Sobre a recorrência mítica ao longo do processo histórico português ver Alberto Araújo e Armando Malheiro da Silva, "Afonso Henriques, o mito fundador e a recorrência mítica. Para uma mitanálise do processo histórico português", in 2" Congresso Histórico de Guimarães, vol. 3, ob. cit., pp. 338-402. 


\section{A concluir...}

Ao longo deste estudo ficaram postas a nu algumas interacções do factual e do ficcional, do histórico, do ideológico e do literário numa tentativa árdua mas aliciante, de reaproximar o inseparável, o que não significa, porém, confundir o inconfundível...

O caso de Sidónio Pais parece-nos ser um bom exemplo da grande permeabilidade do exercício historiográfico à subjectividade psíquica, à ganga ideológica e ao magma simbólico veiculado, acumulado e difundido através do sujeito-narrador. Mas apesar de tão subtis e profundas contaminações é possível distinguir certas linhas de água, certos separadores que assinalam a diferença essencial. Se a ficção for definida como o que podia ter acontecido, o registo histórico tem de excluir a possibilidade e assentar na realidade fáctica e vivida, reconstituindo-a e interpretando-a através de um naipe complexo de "filtros", ou seja, de uma crítica apurada do maior número possível de fontes de informação díspares e complementares num fazer e refazer contínutos em busca de verdades sempre presentes, ocultas, incompletas e mutáveis... 